\title{
SPECTRA FOR:
}

Ring-Opening, Ring-Closing Metathesis (RORCM) Reactions of 7-Azanorbornene Derivatives. An Entry into Perhydroindolines.

$$
\text { Zhuqing Liu and Jon D. Rainier* }
$$

Department of Chemistry, University of Utah, 315 South 1400 East, Salt Lake City UT, 84112

${ }^{1} \mathrm{H},{ }^{13} \mathrm{C}$, and ${ }^{1} \mathrm{H},{ }^{1} \mathrm{H}$ COSY DATA for $7, \mathbf{8}, \mathbf{1 0}, \mathbf{1 1}, \mathbf{1 3 - 3 1}$, and 33 . 


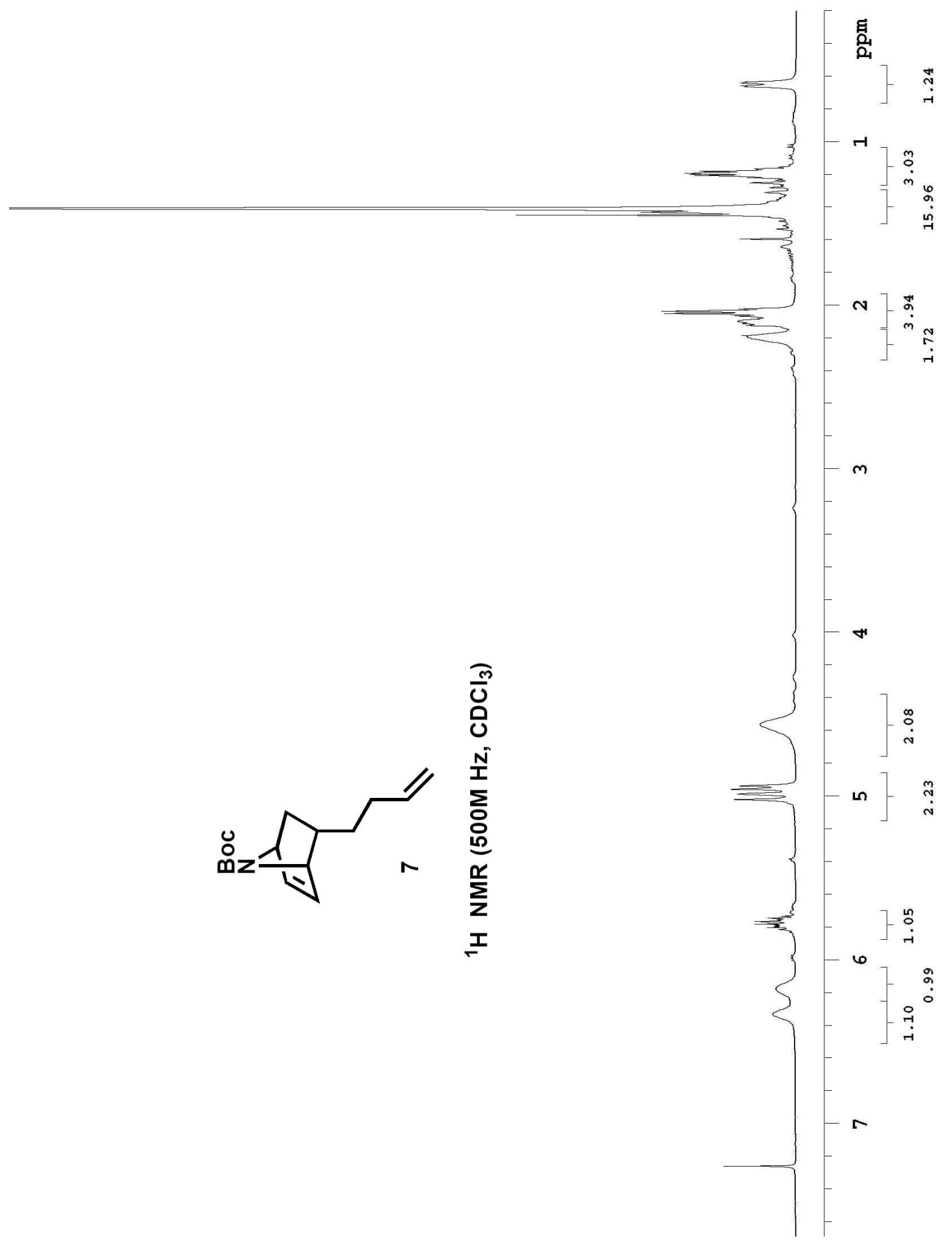




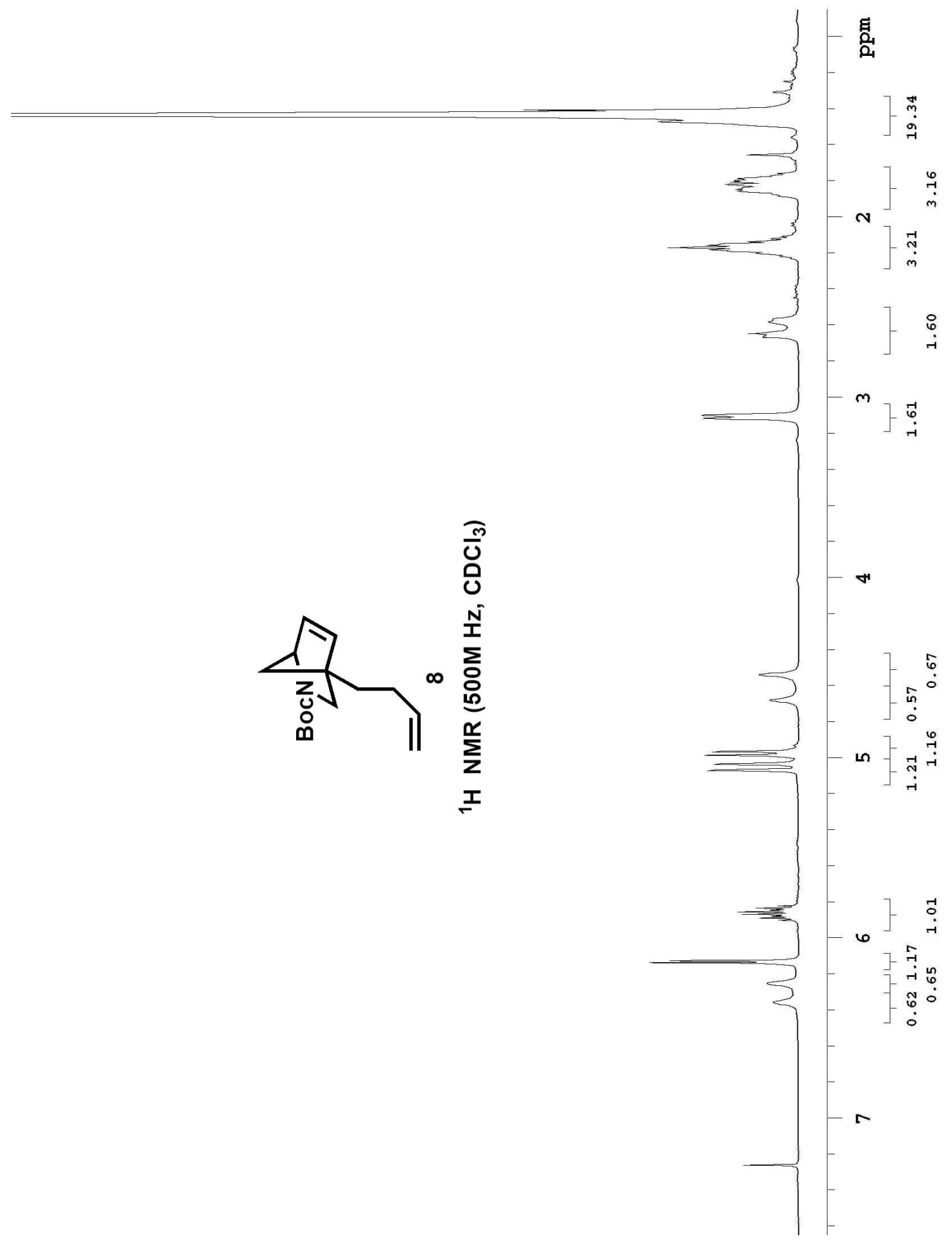




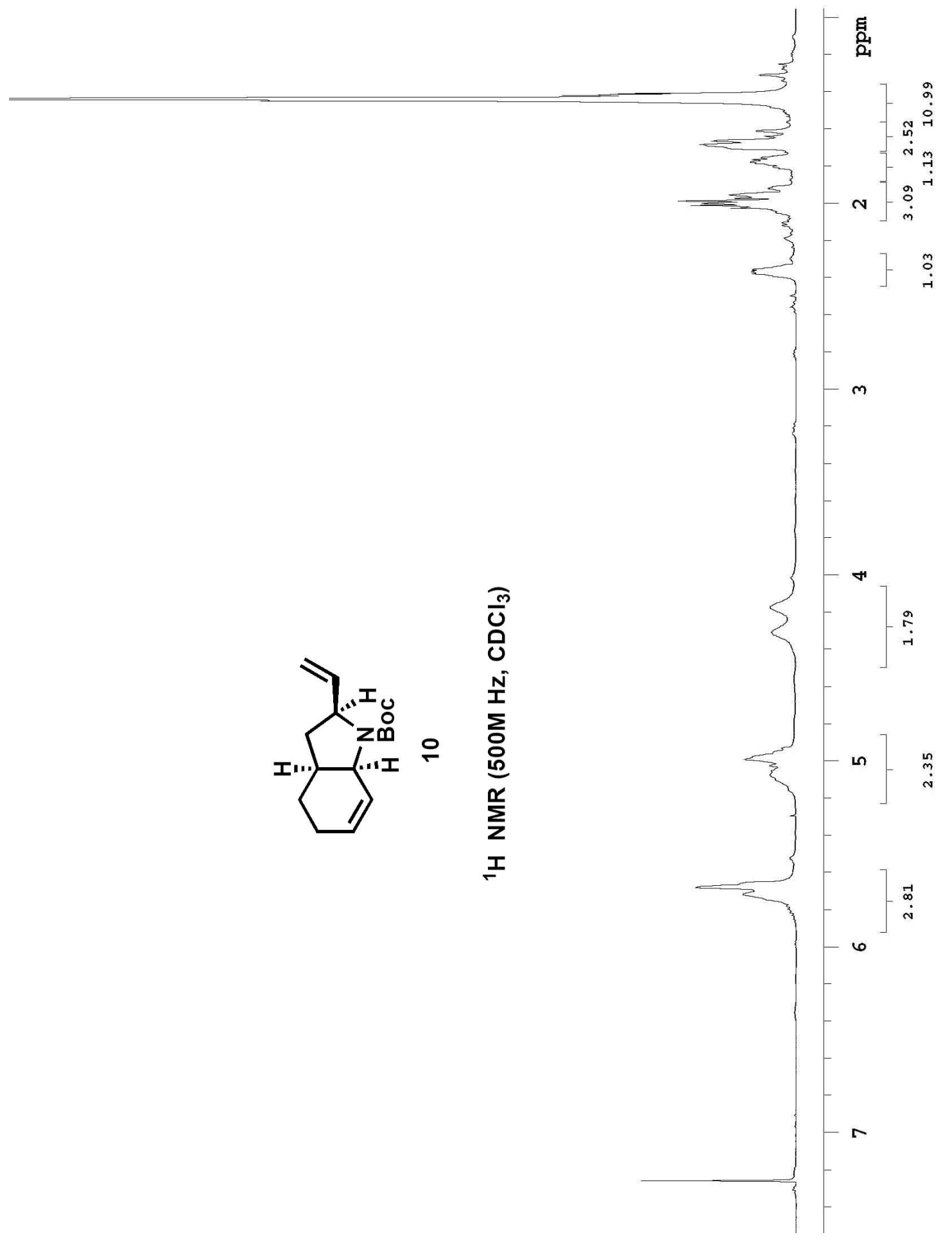




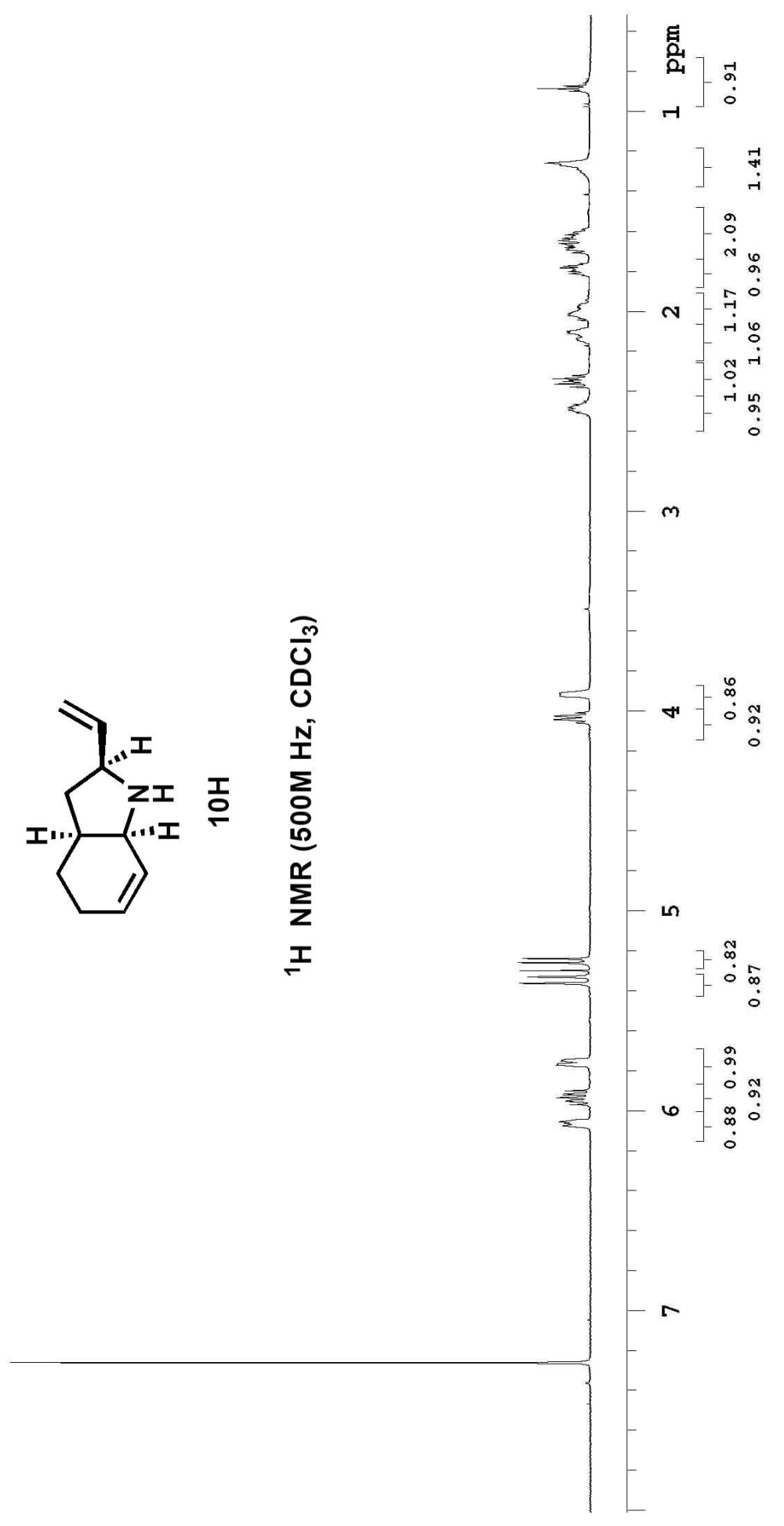




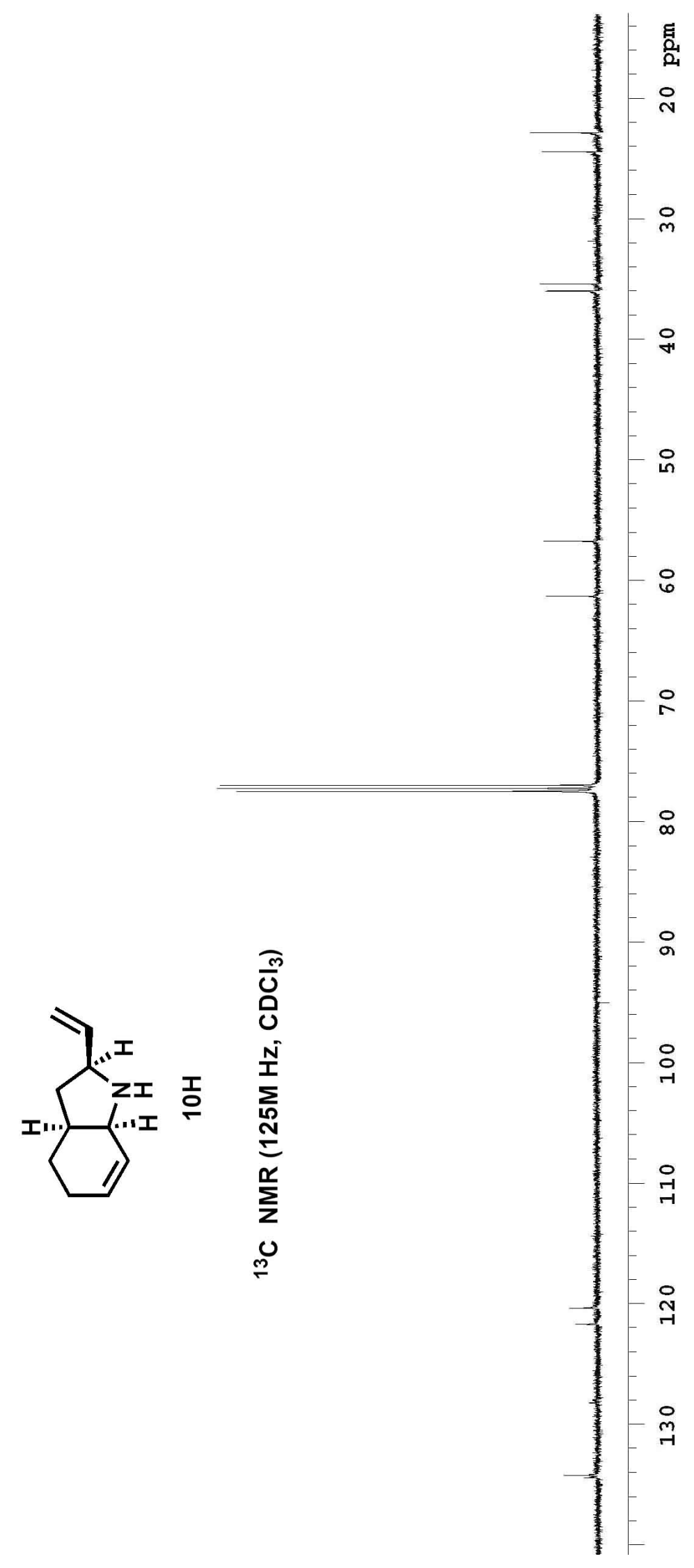




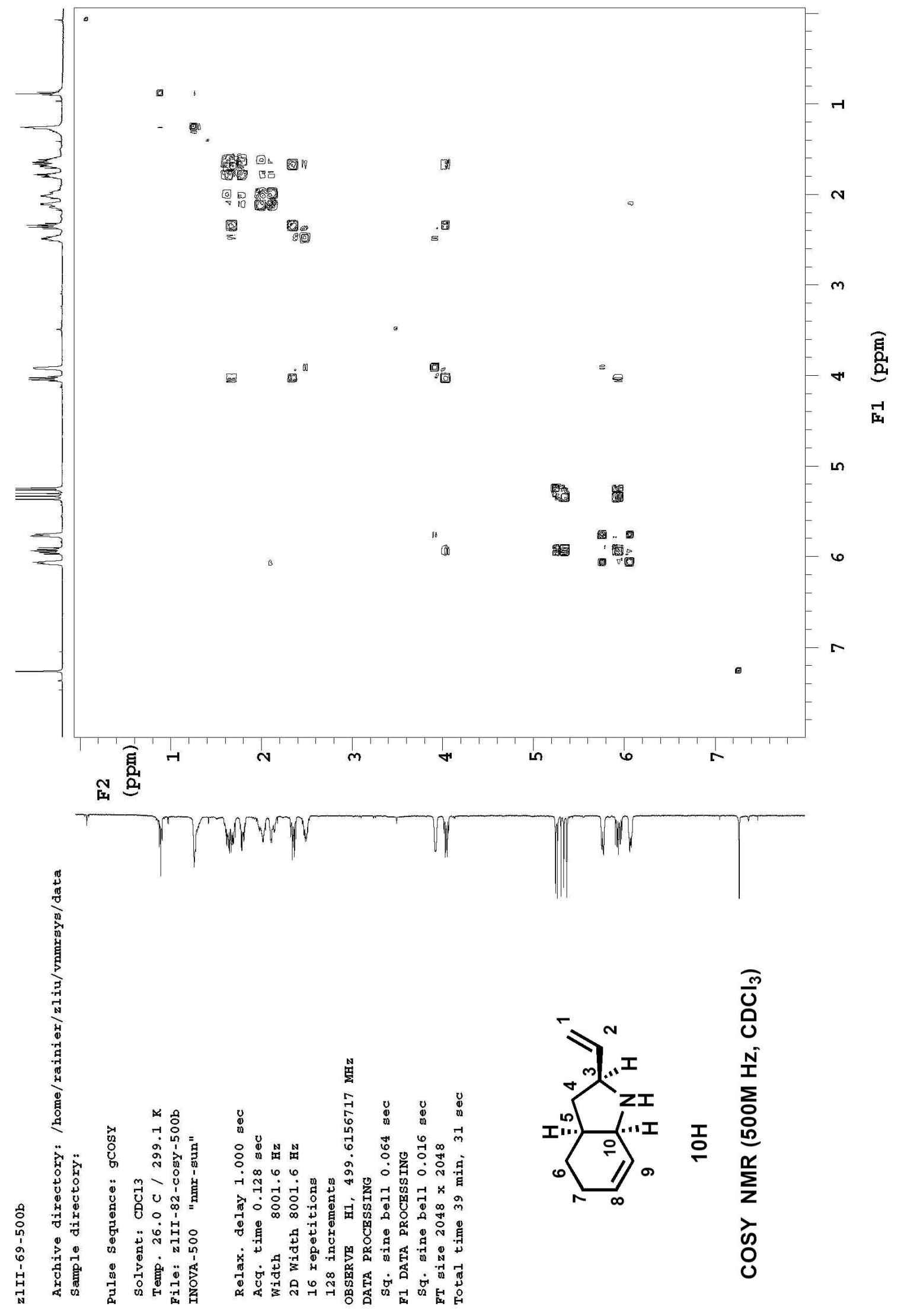




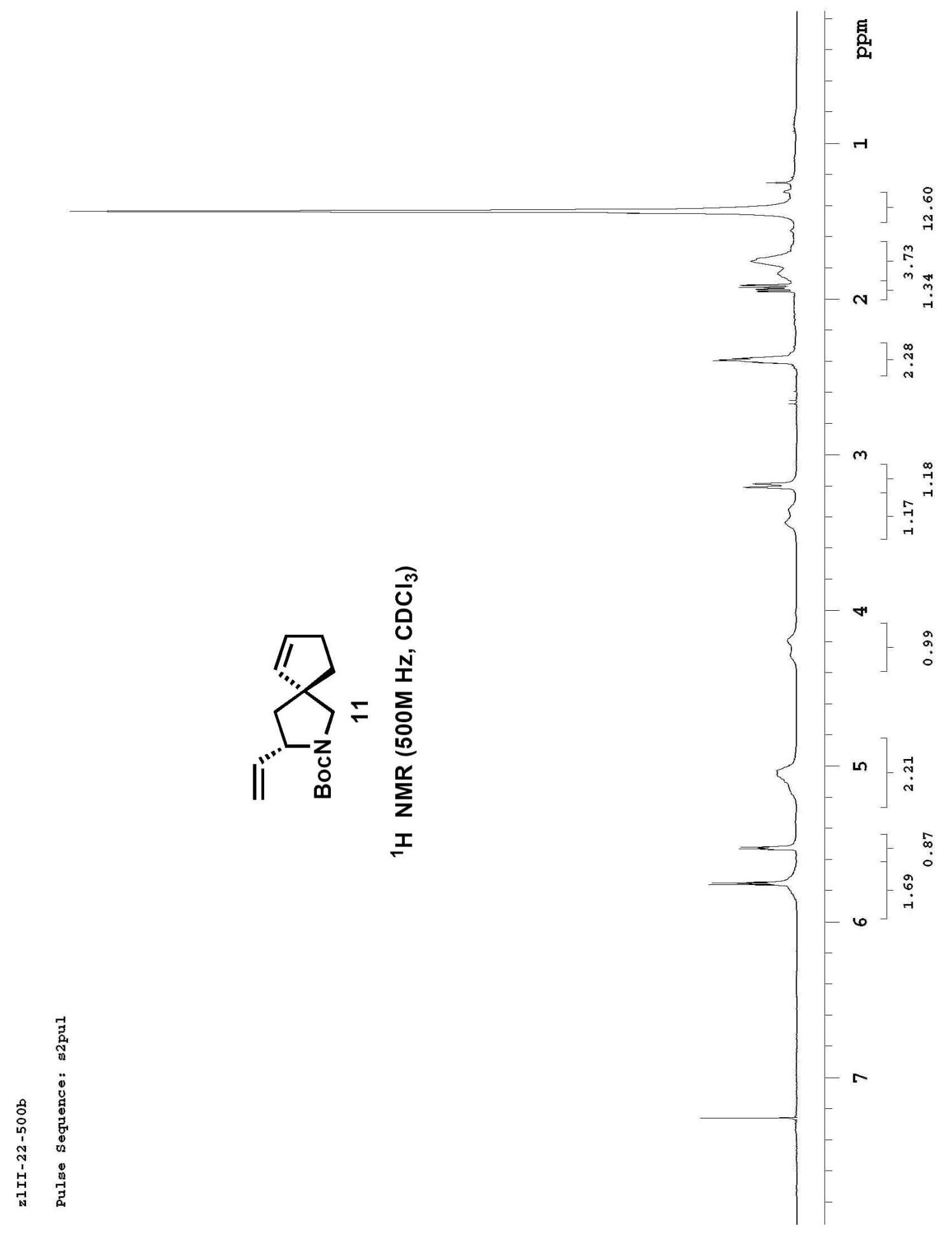




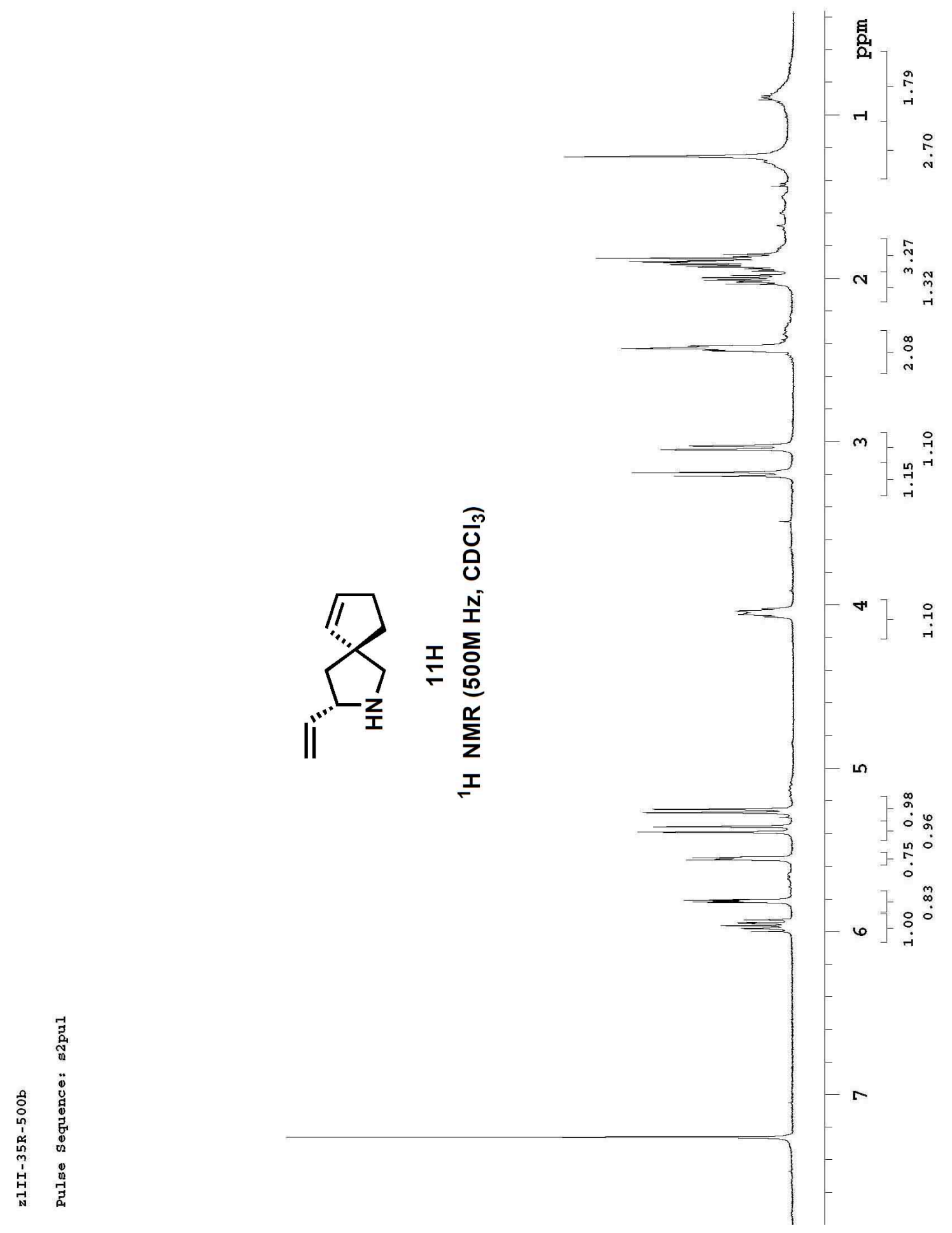




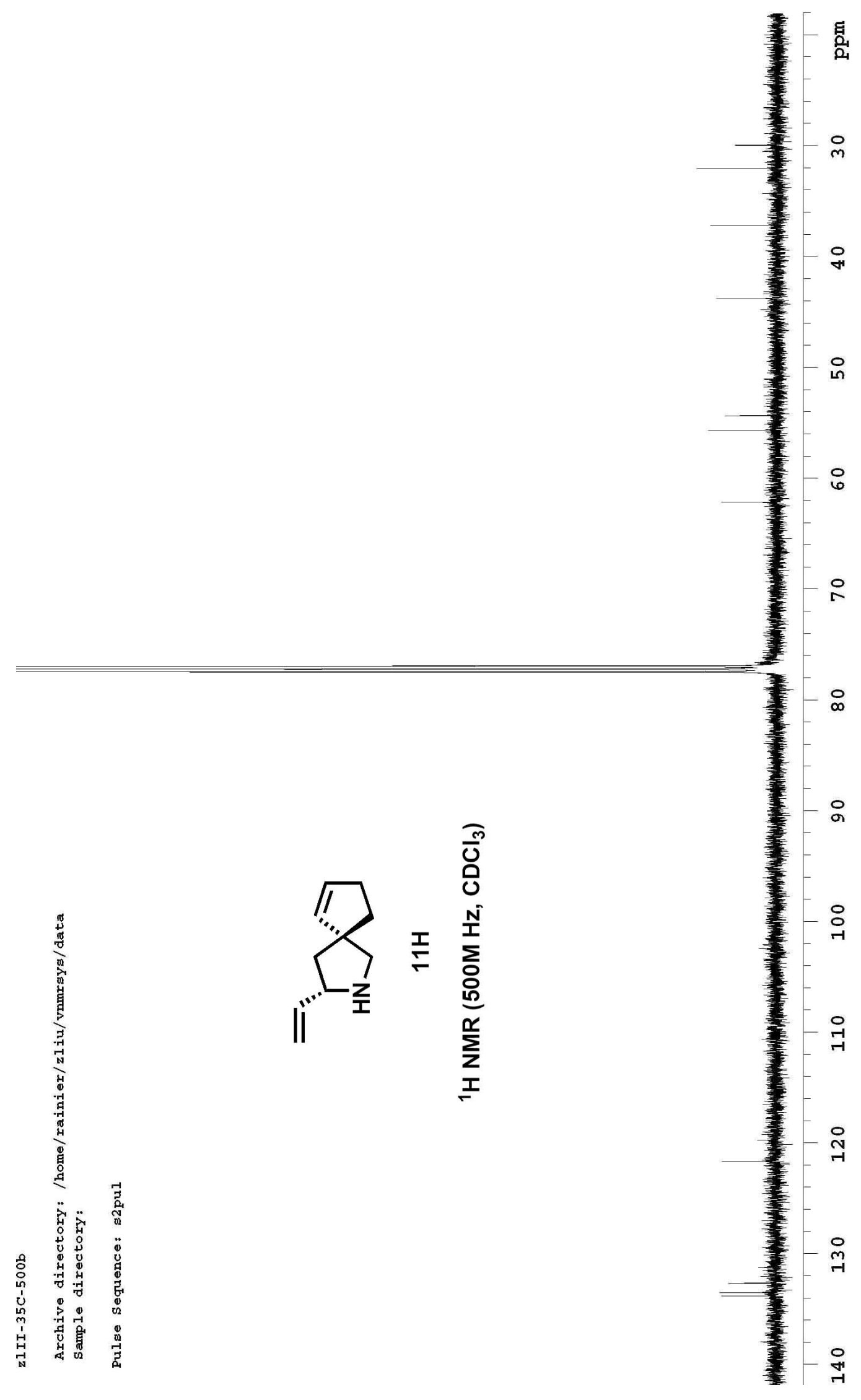




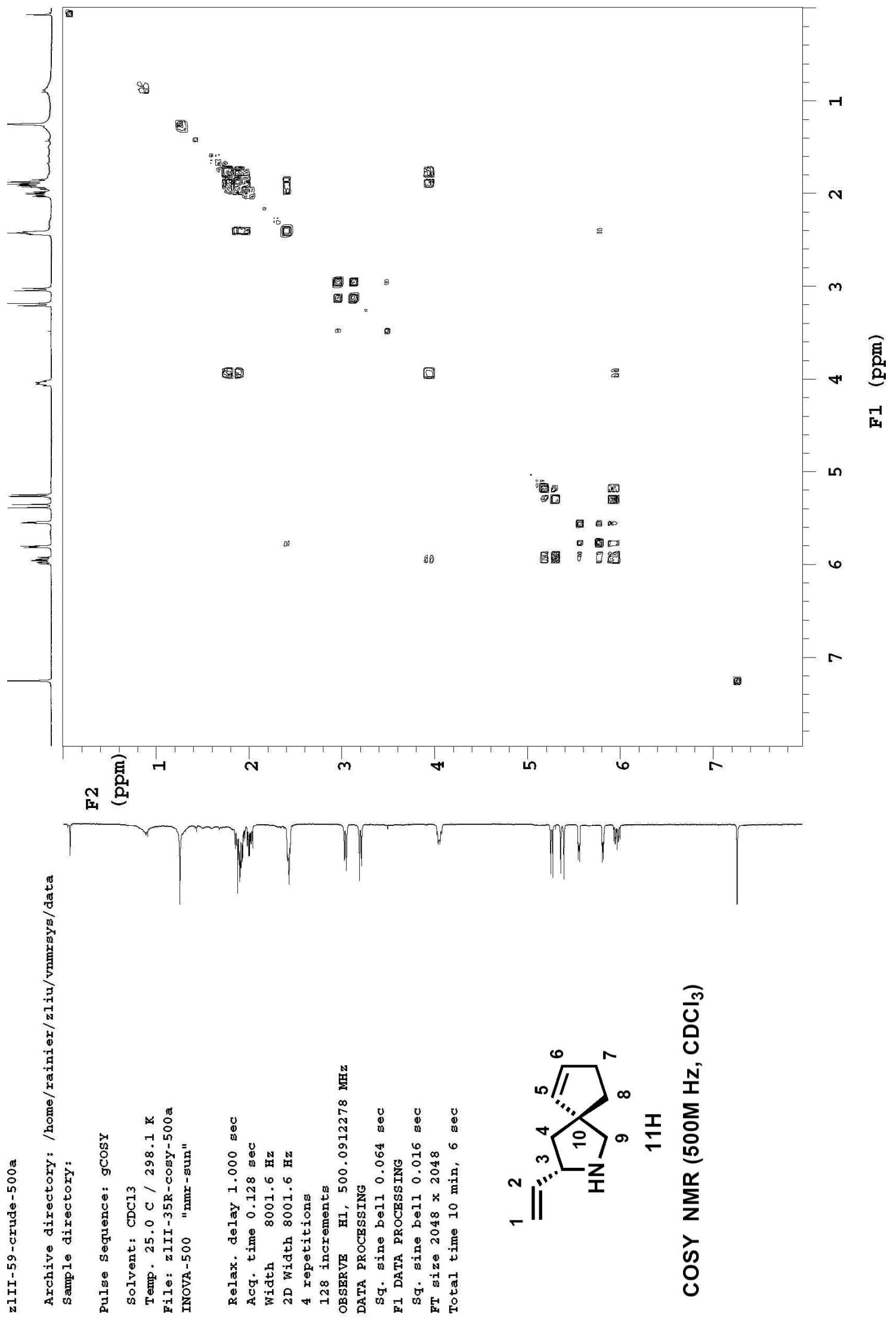




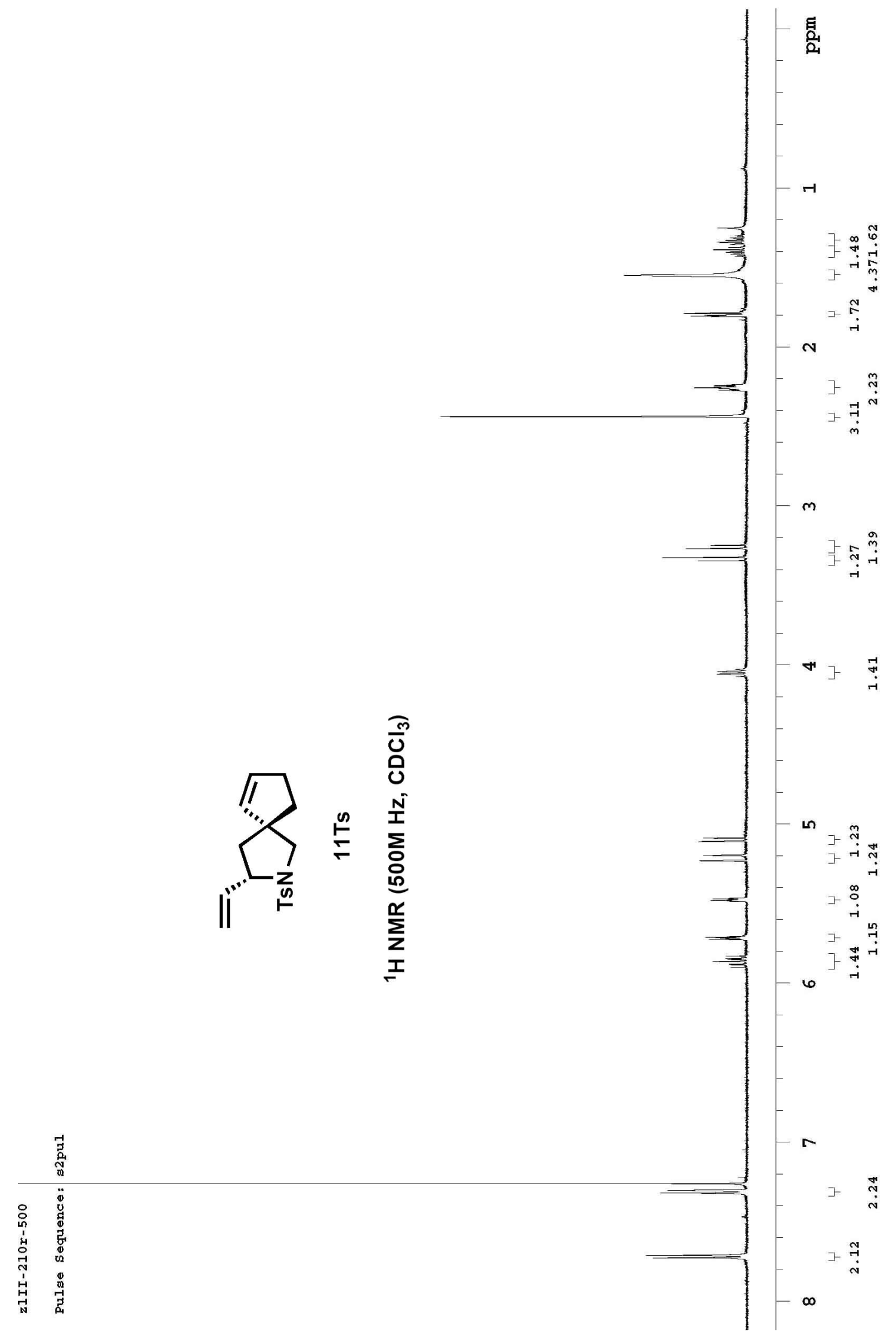




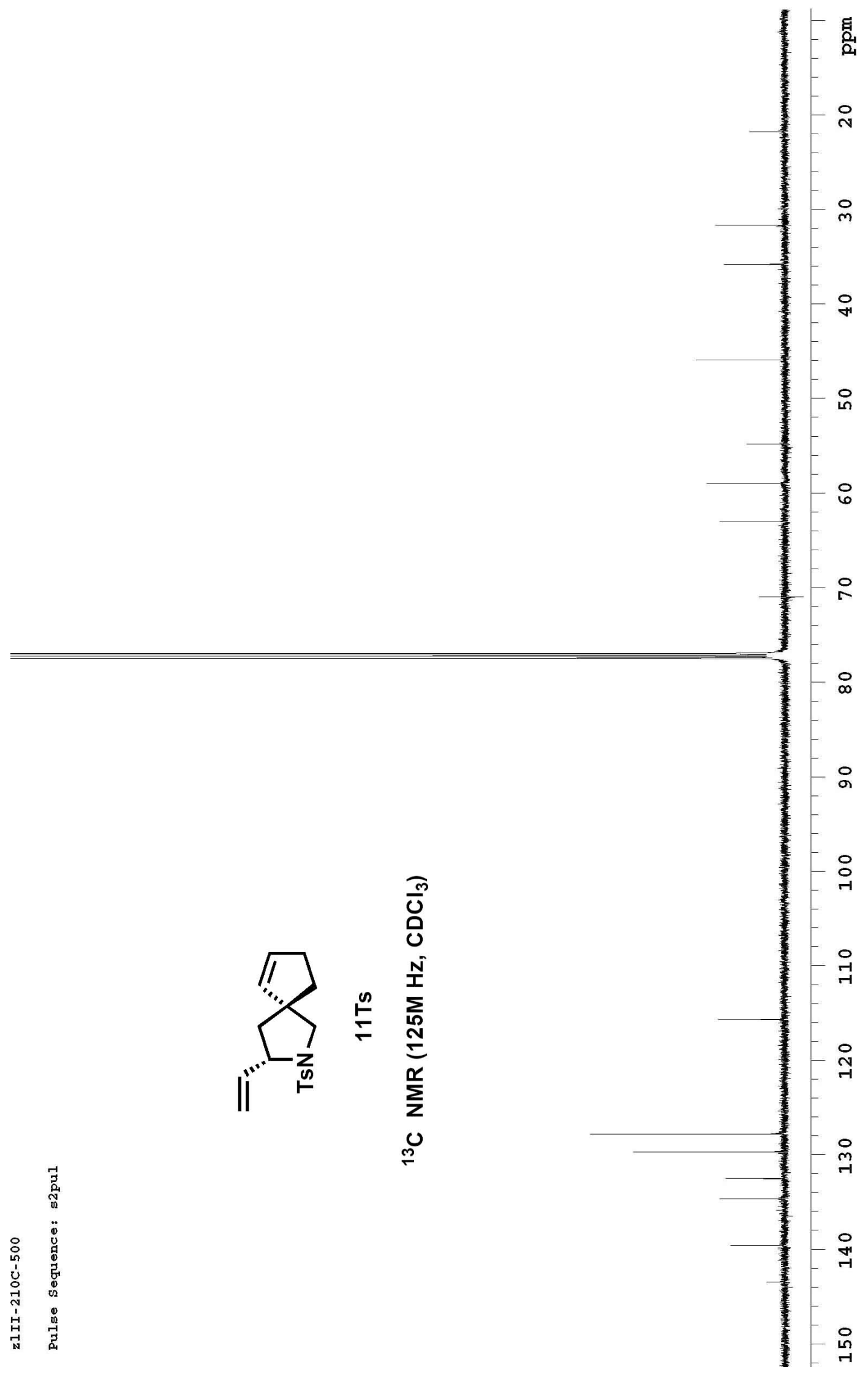




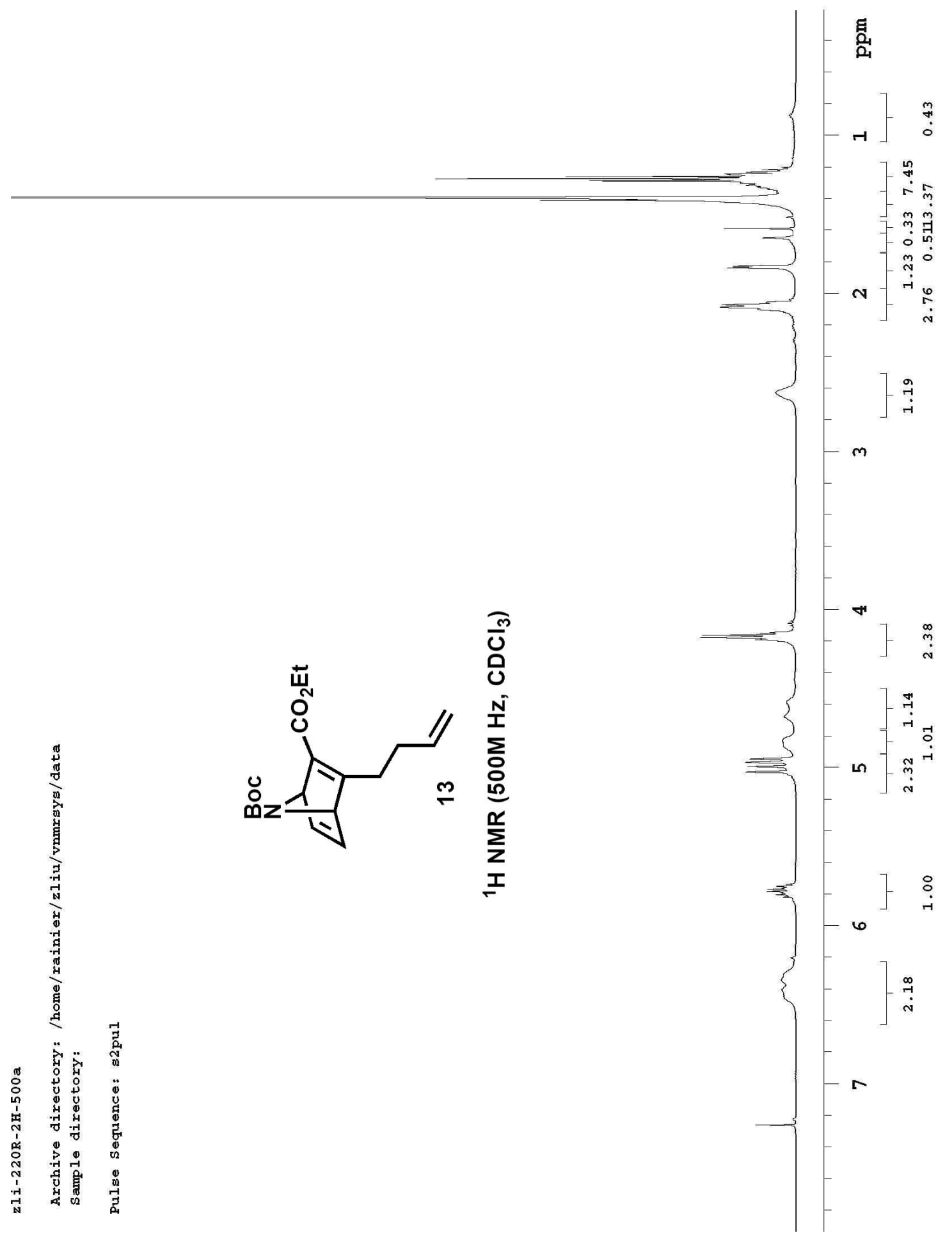




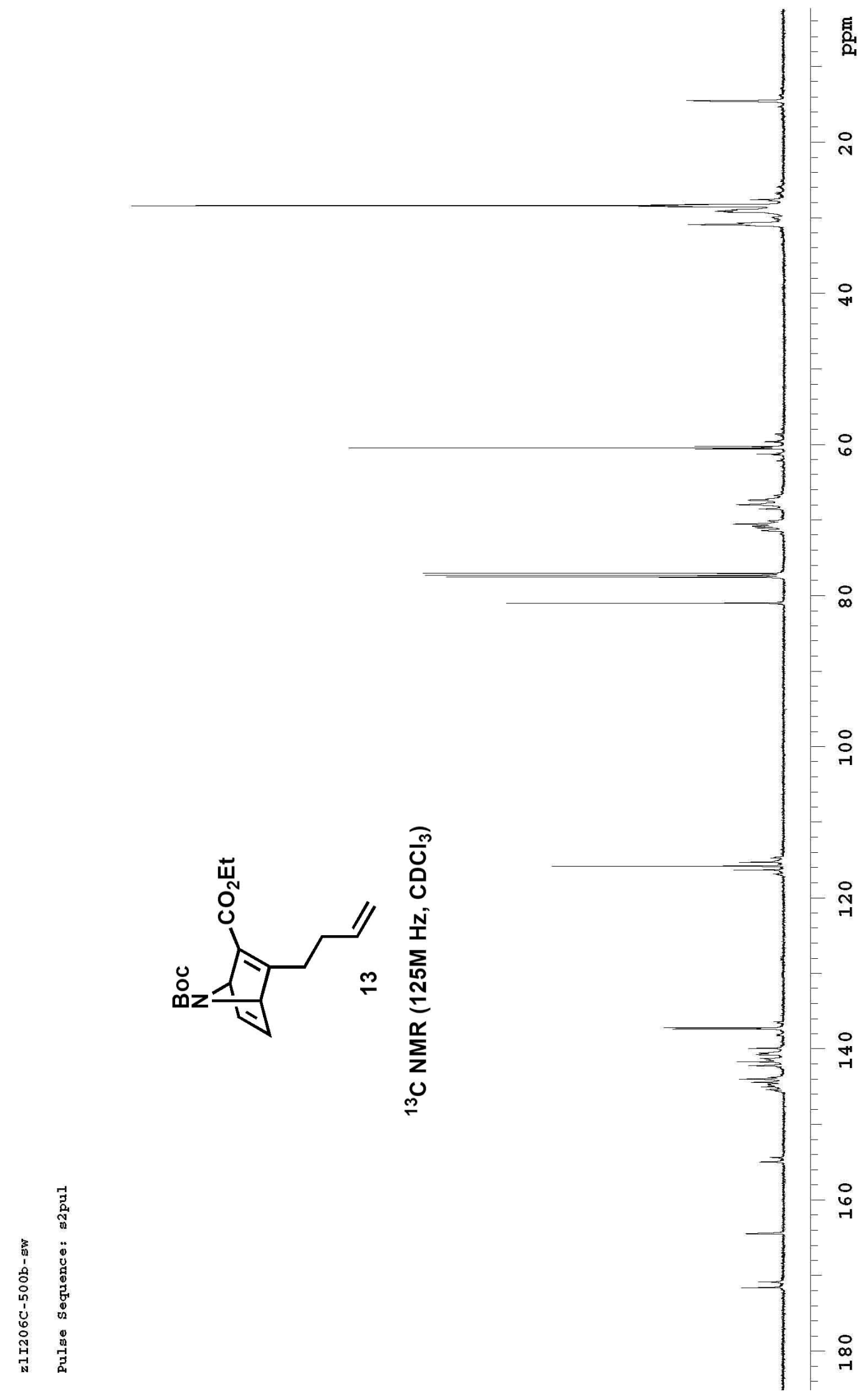




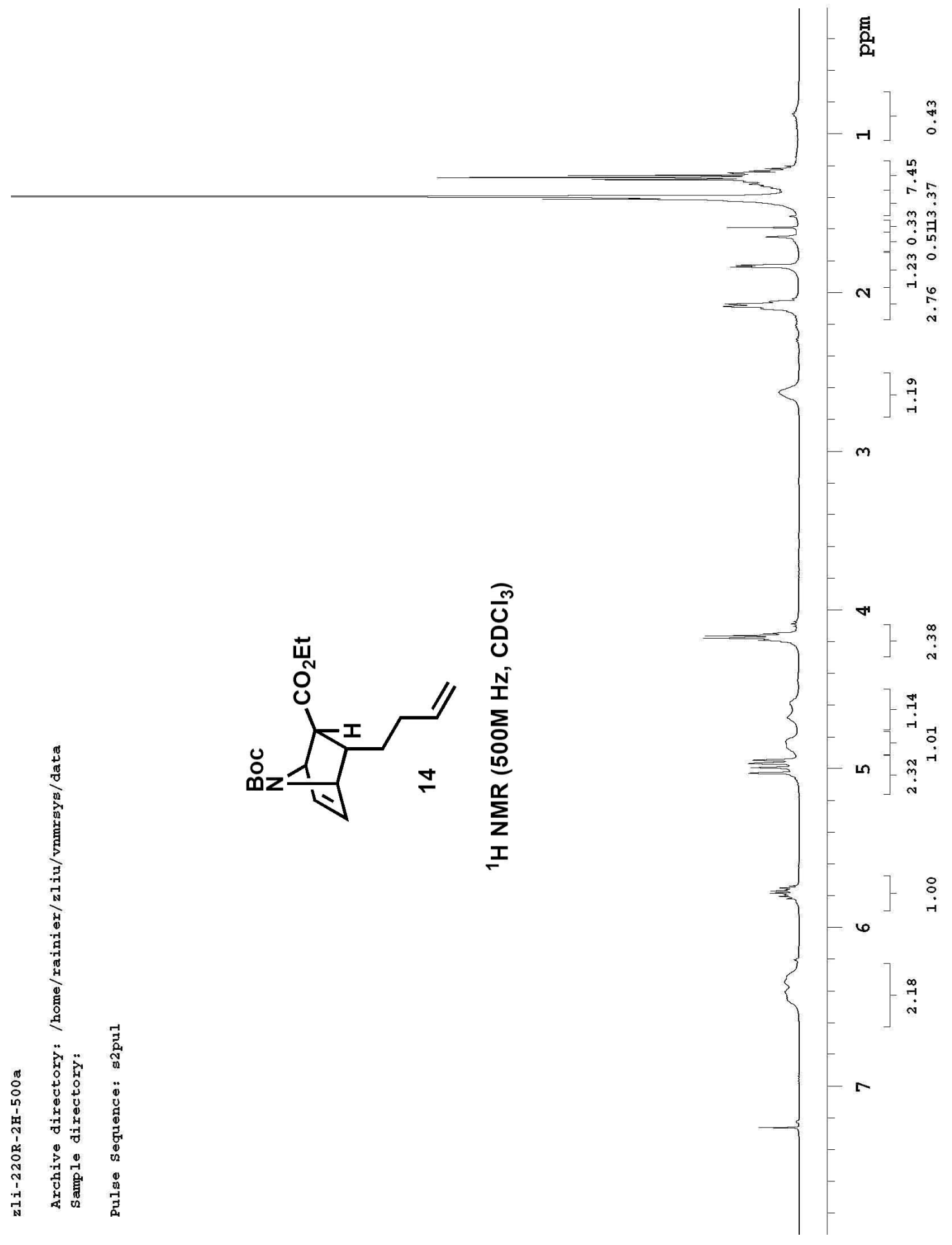




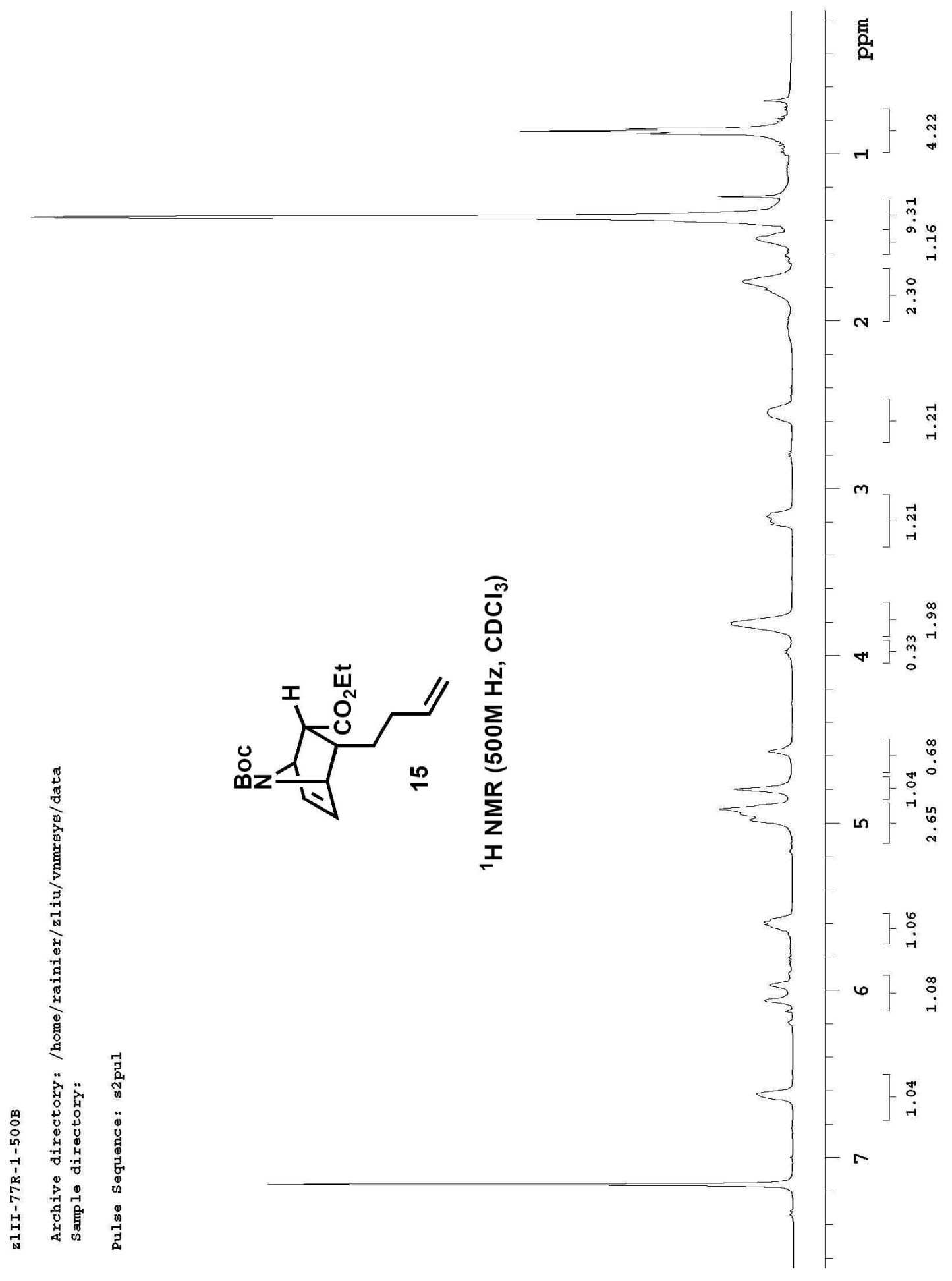




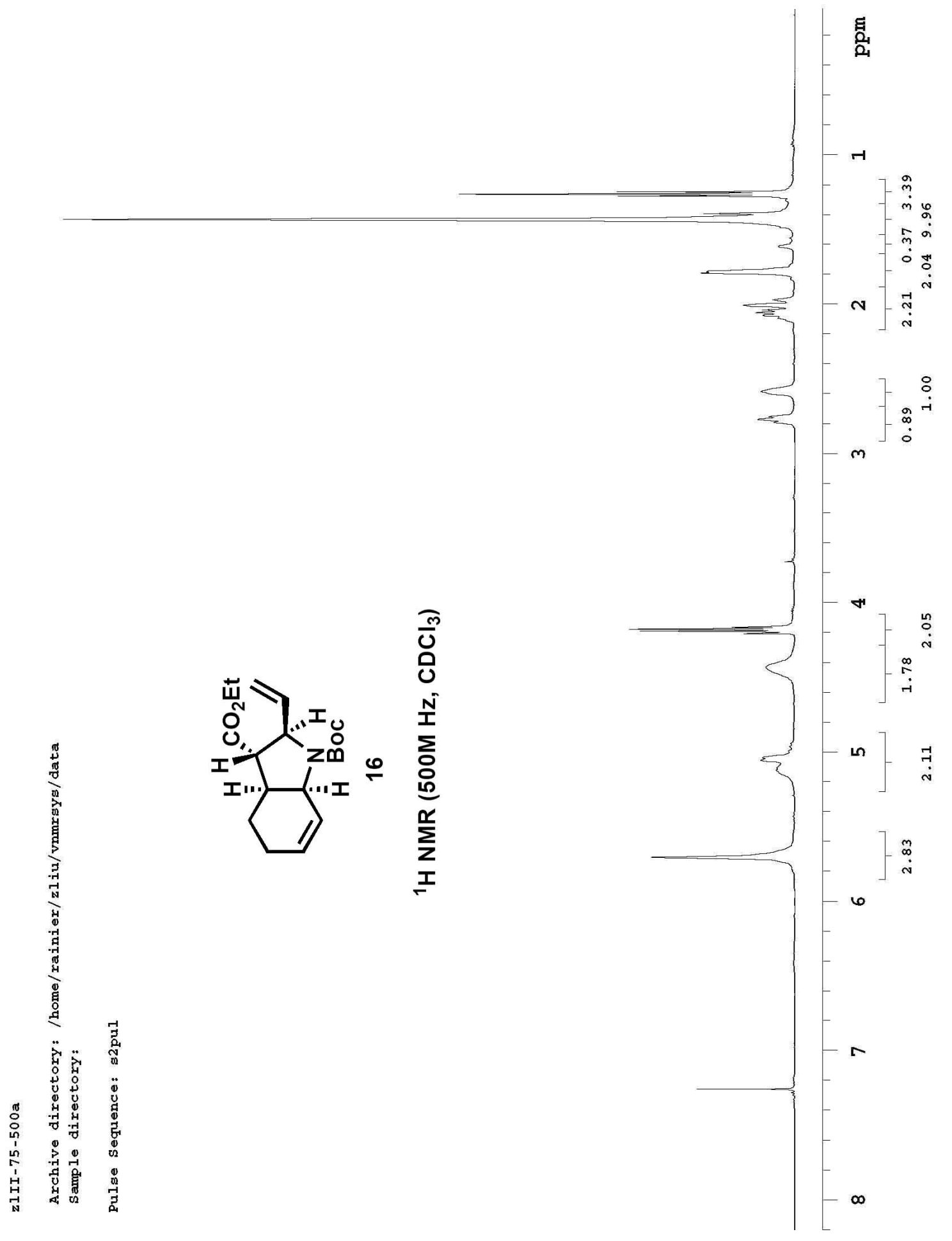




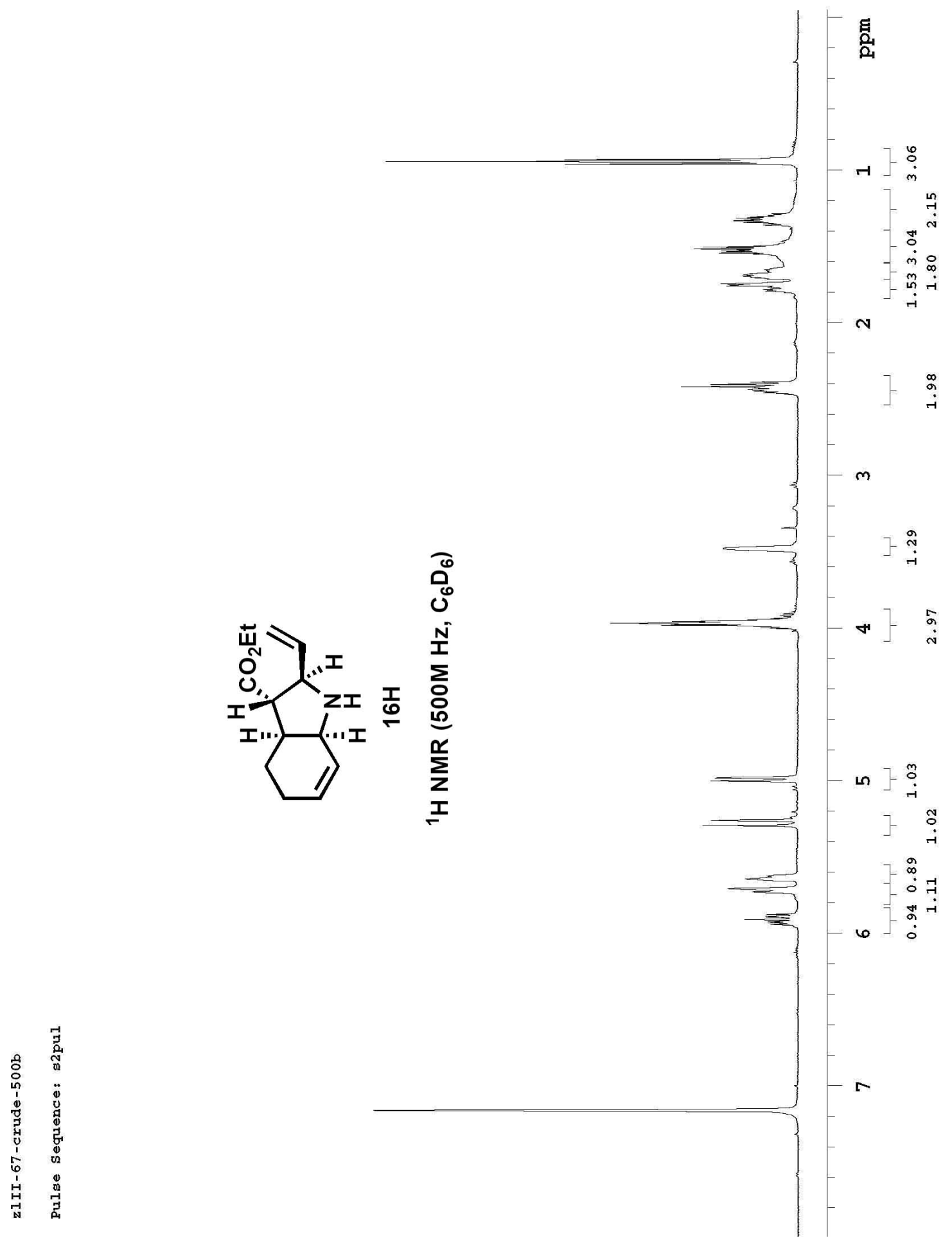




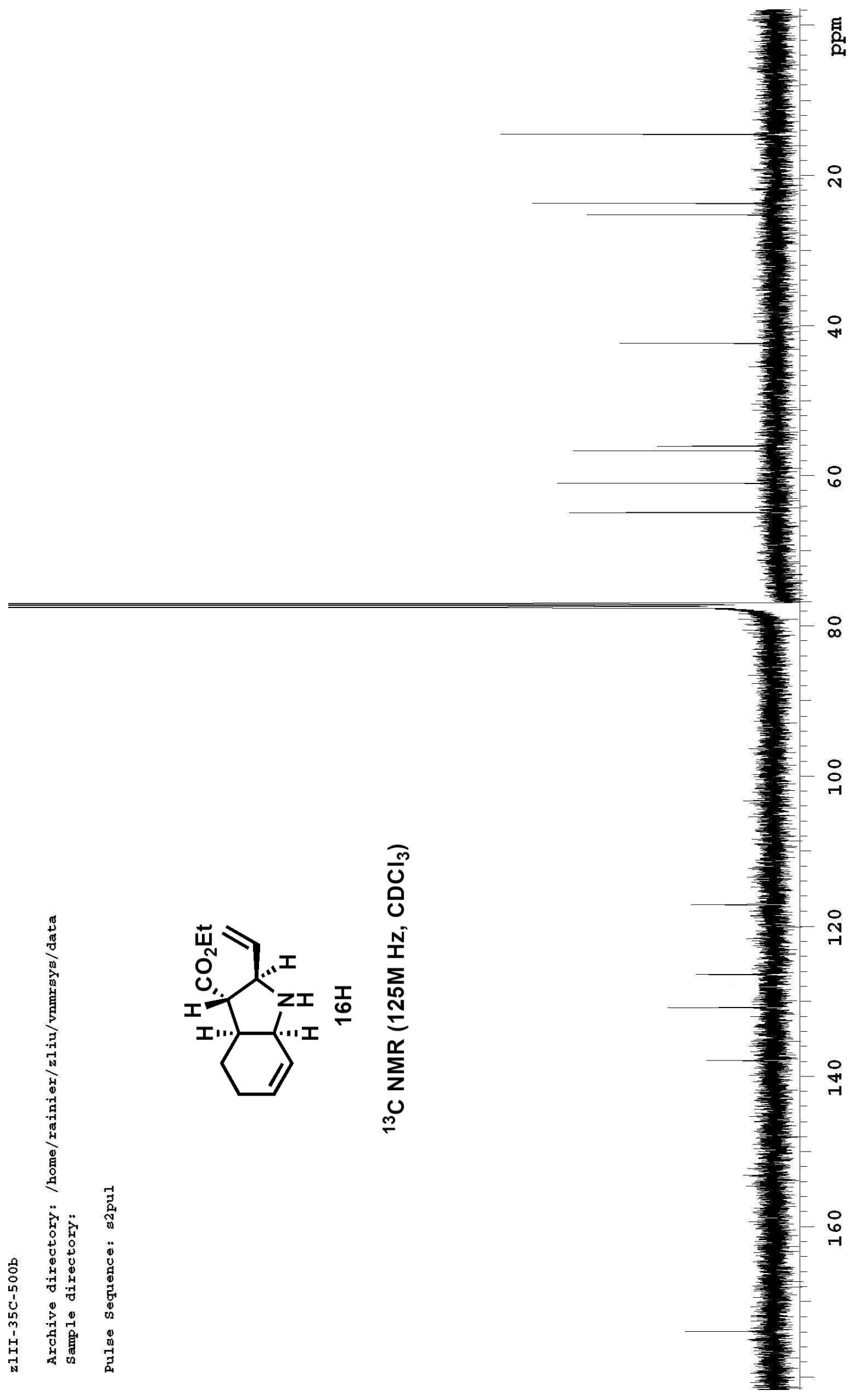



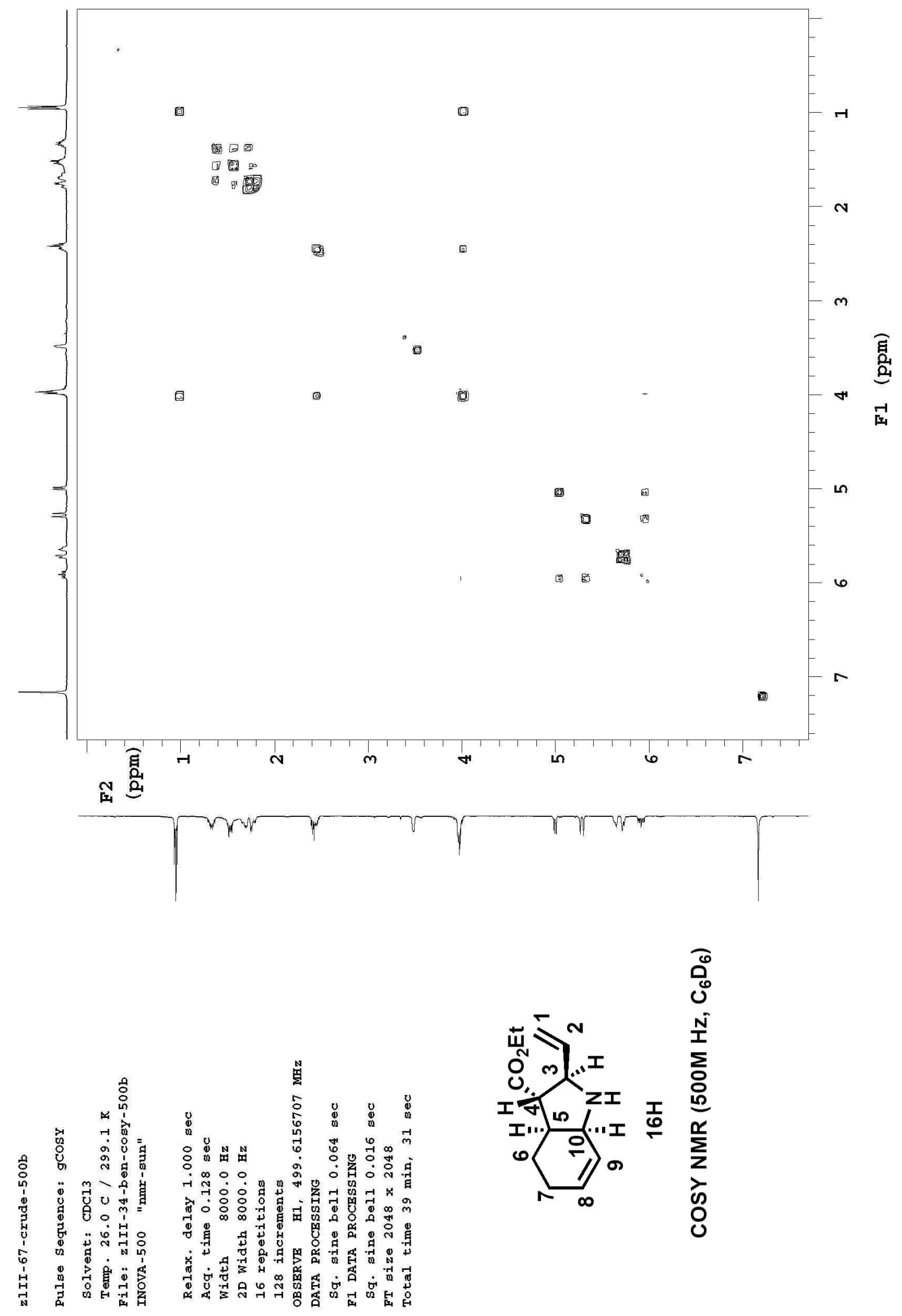


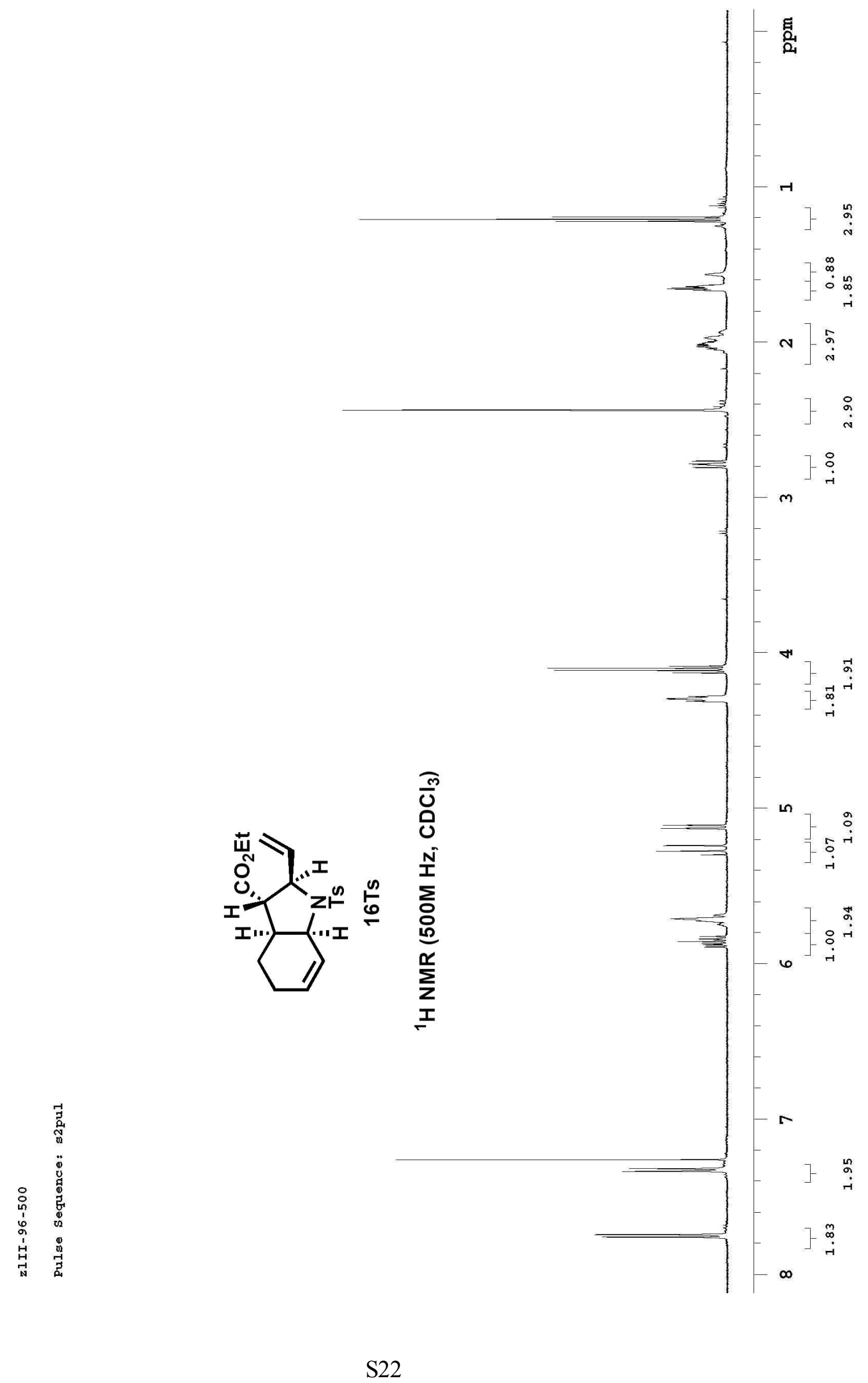



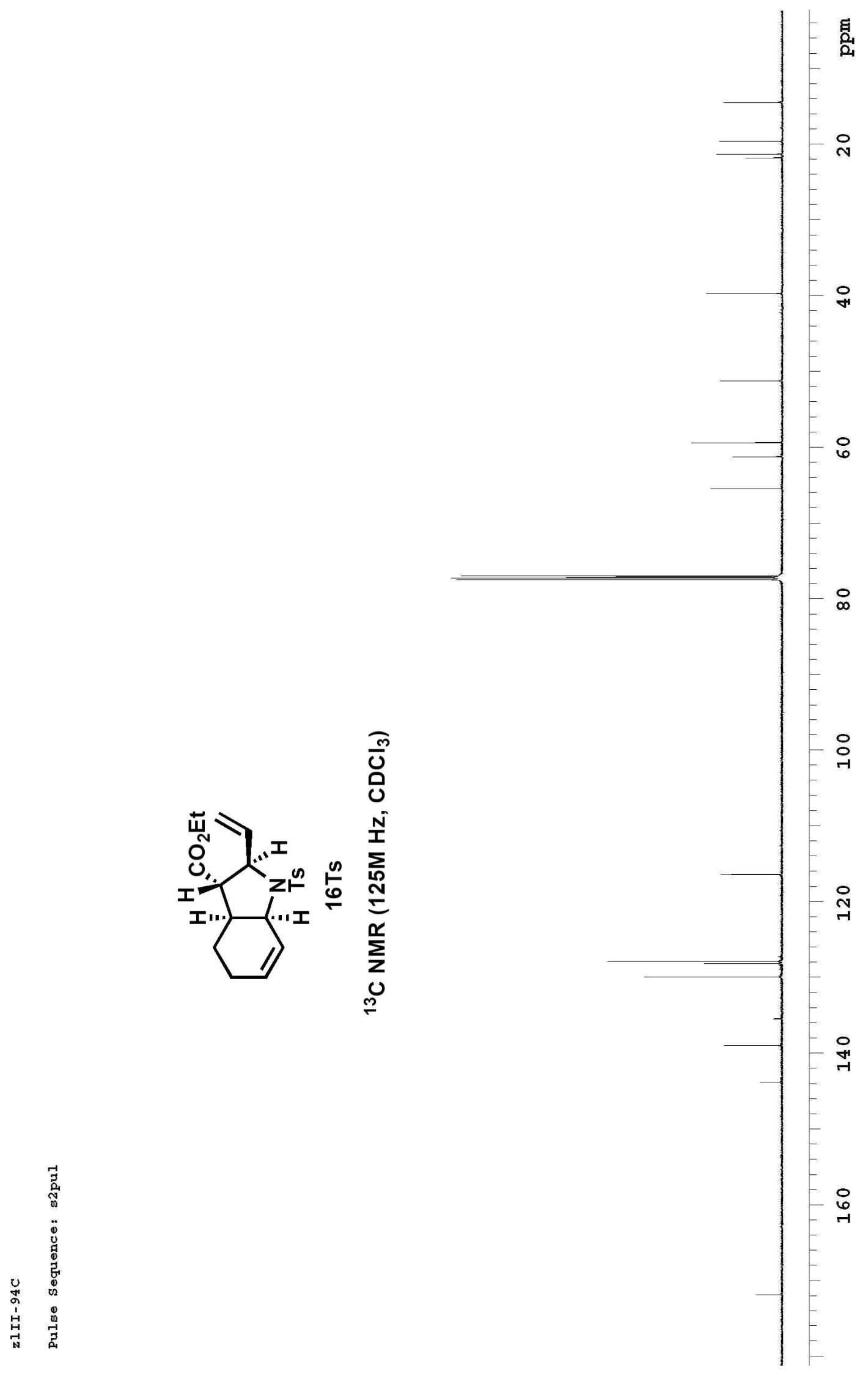


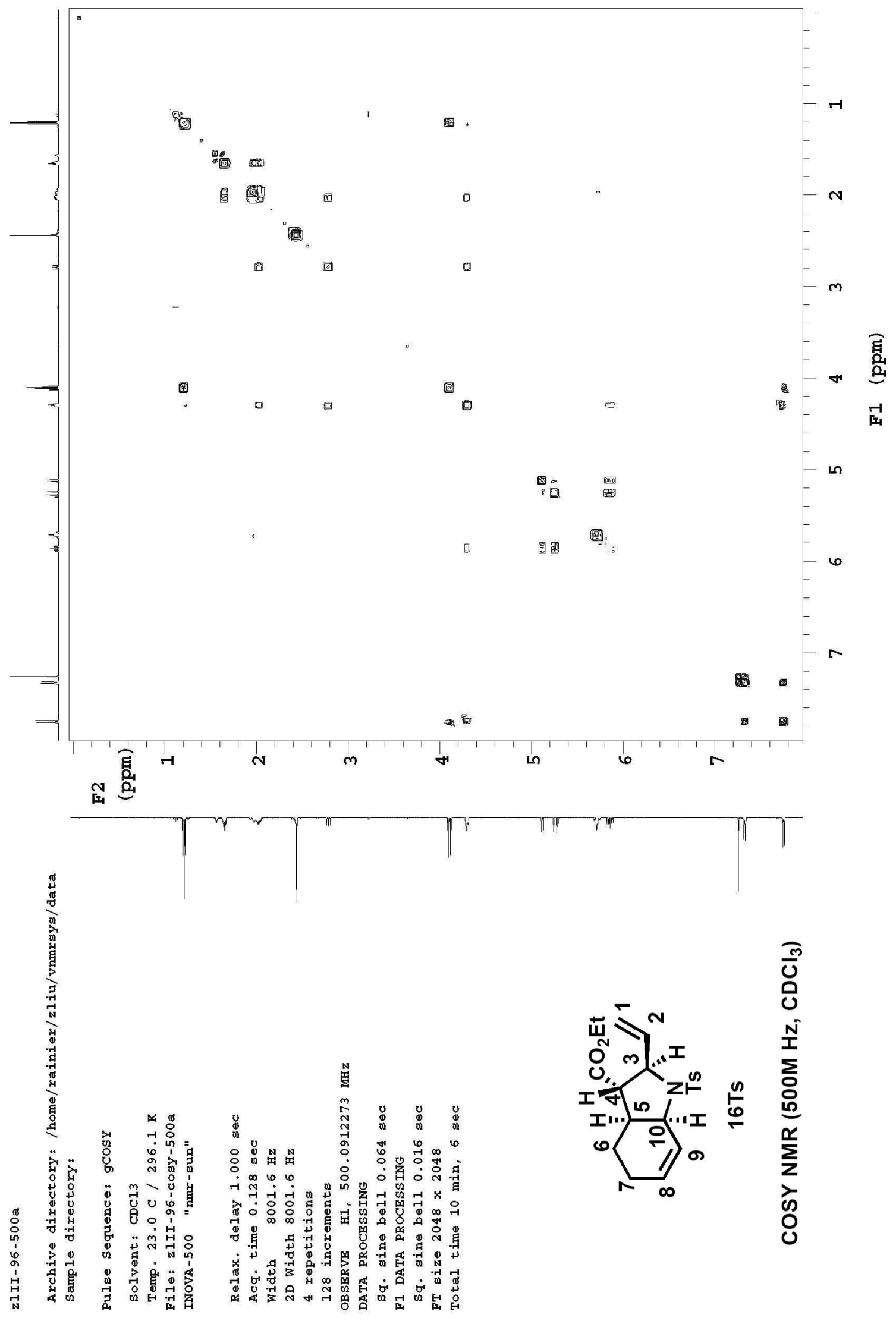




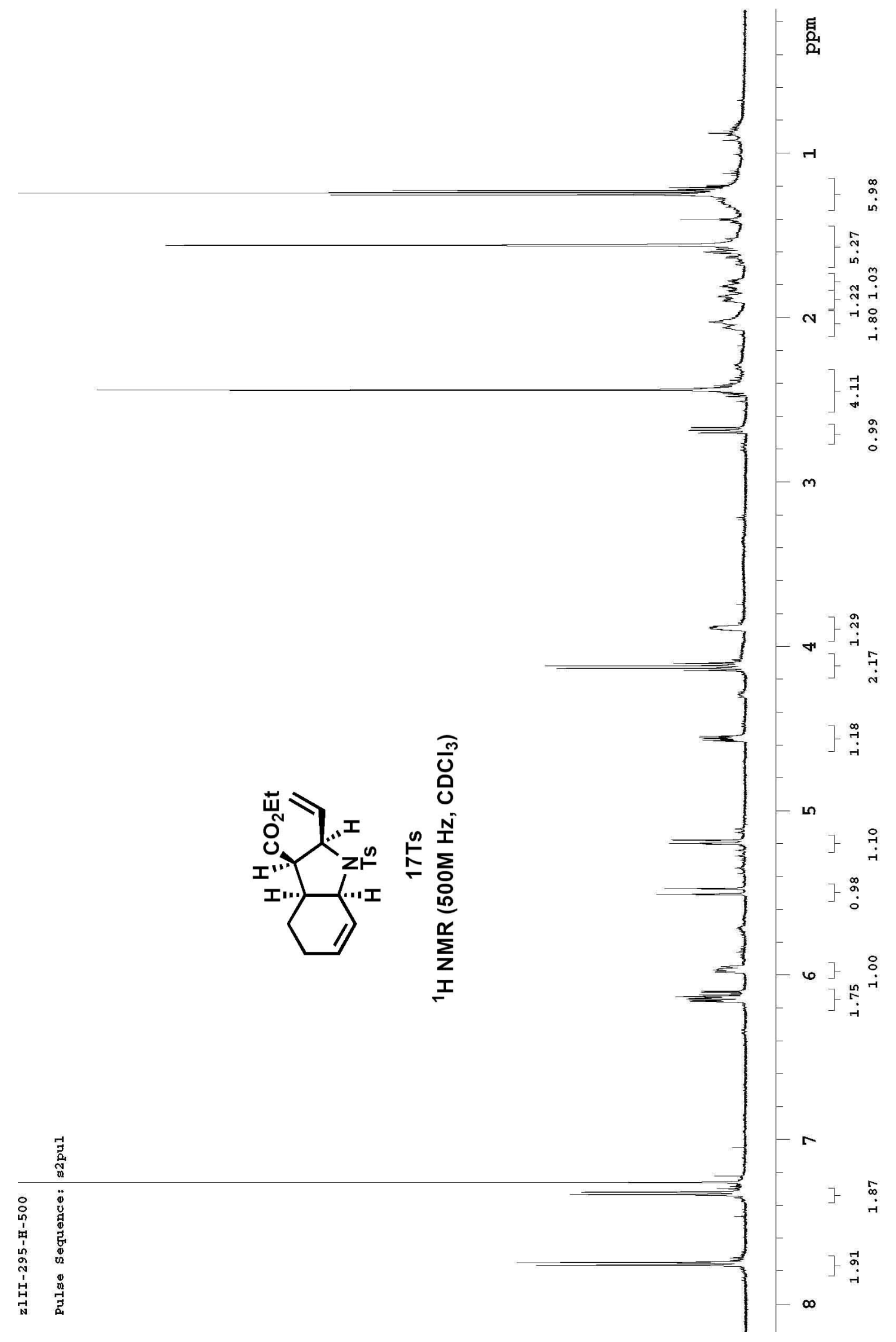




$$
4
$$



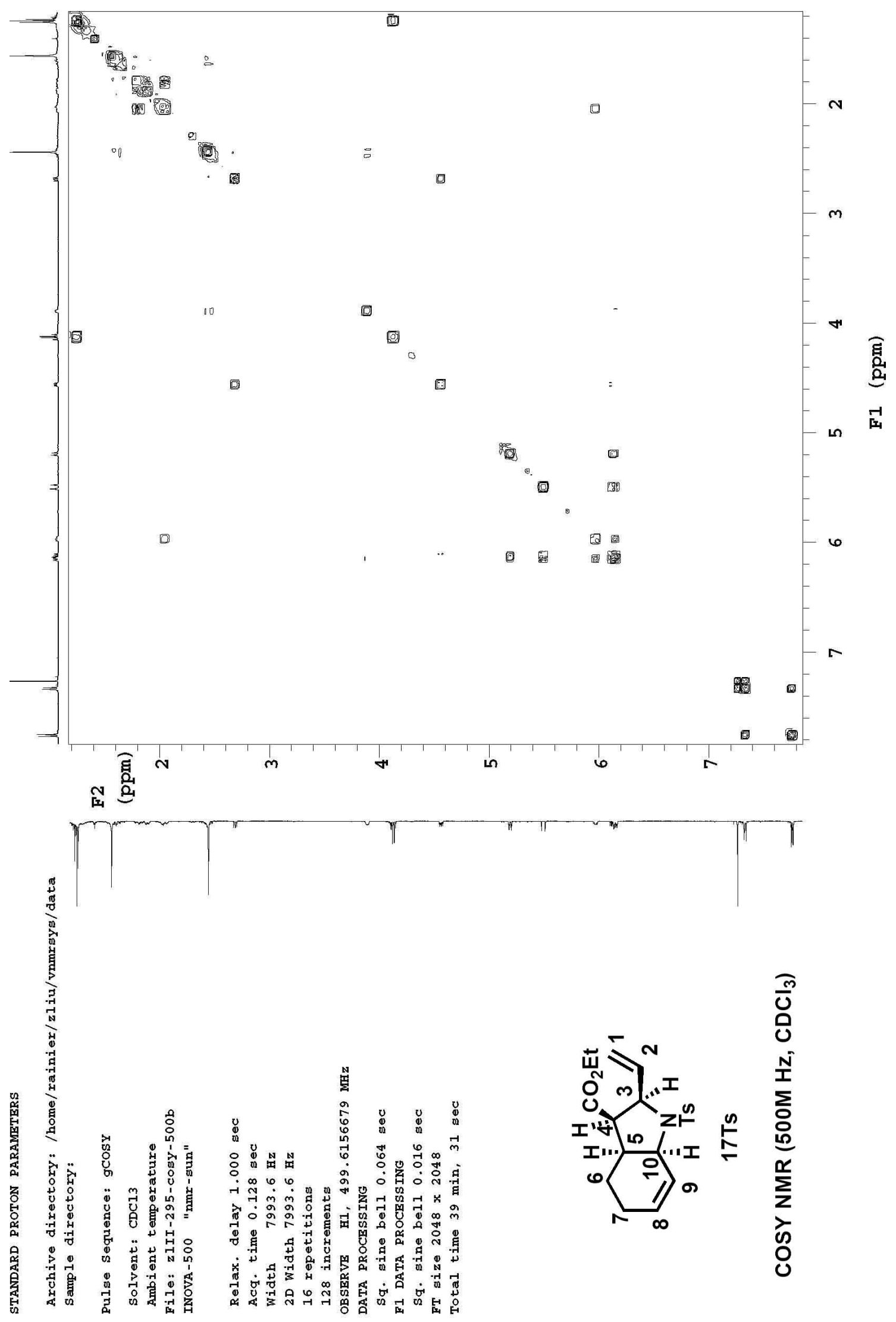


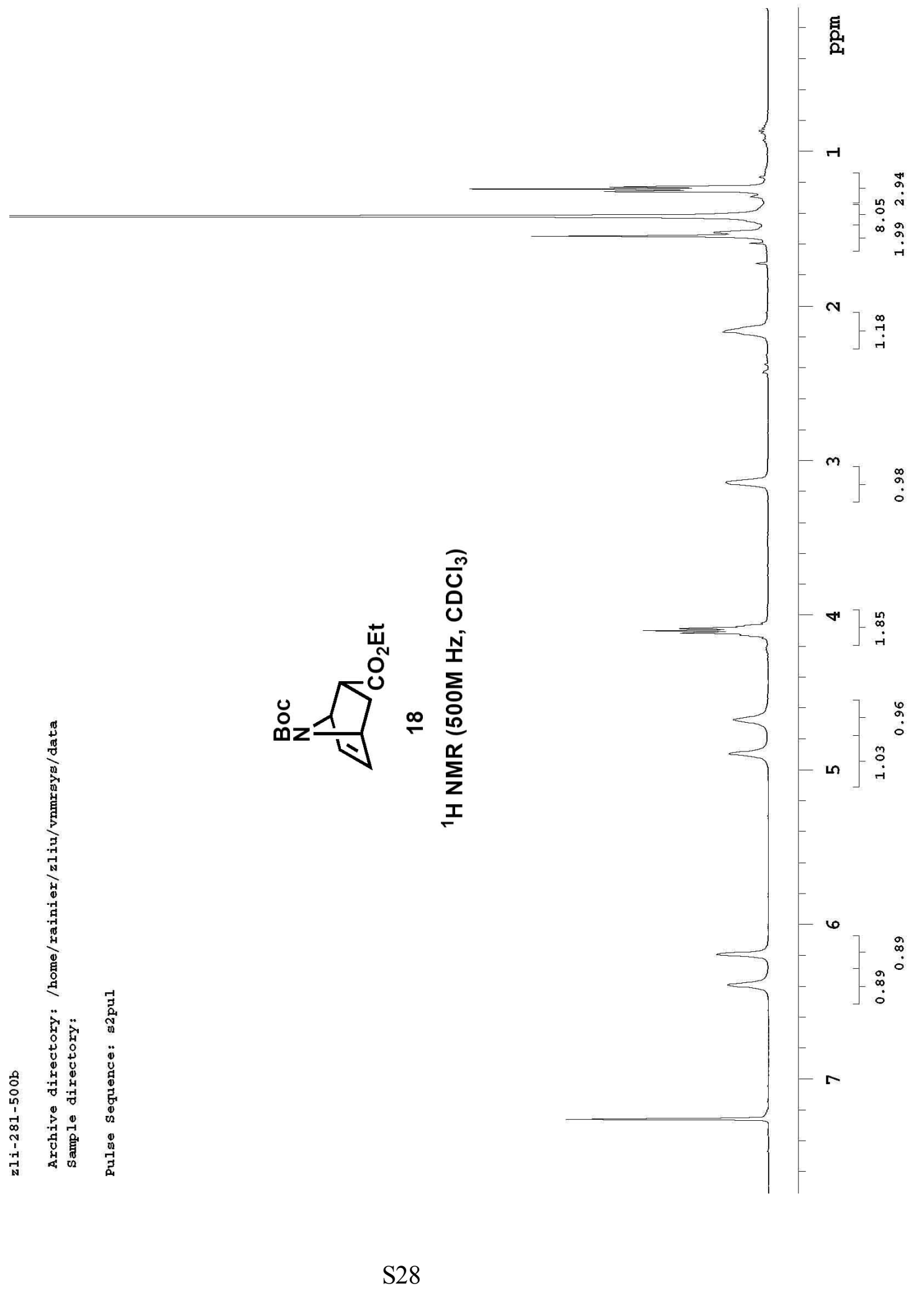




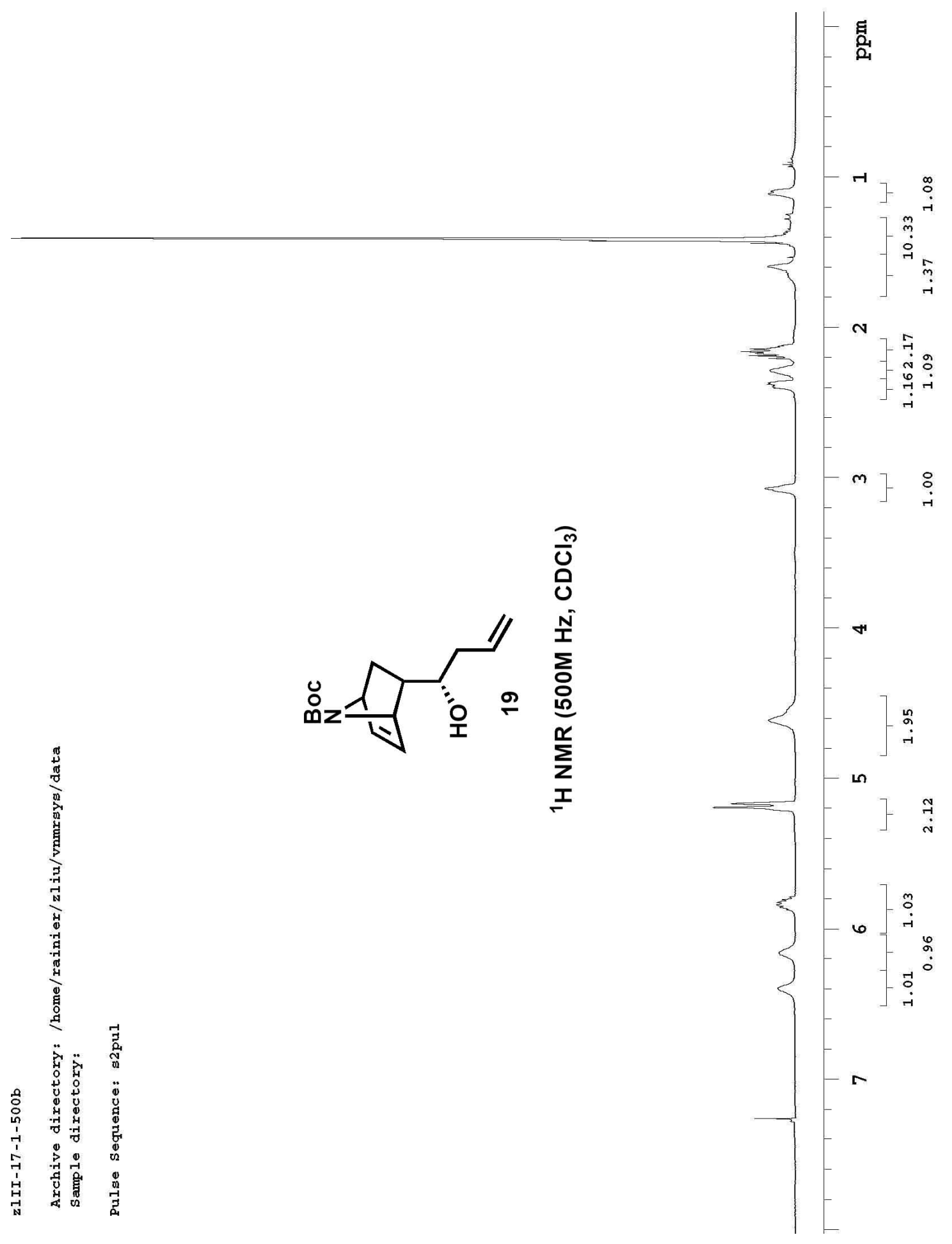




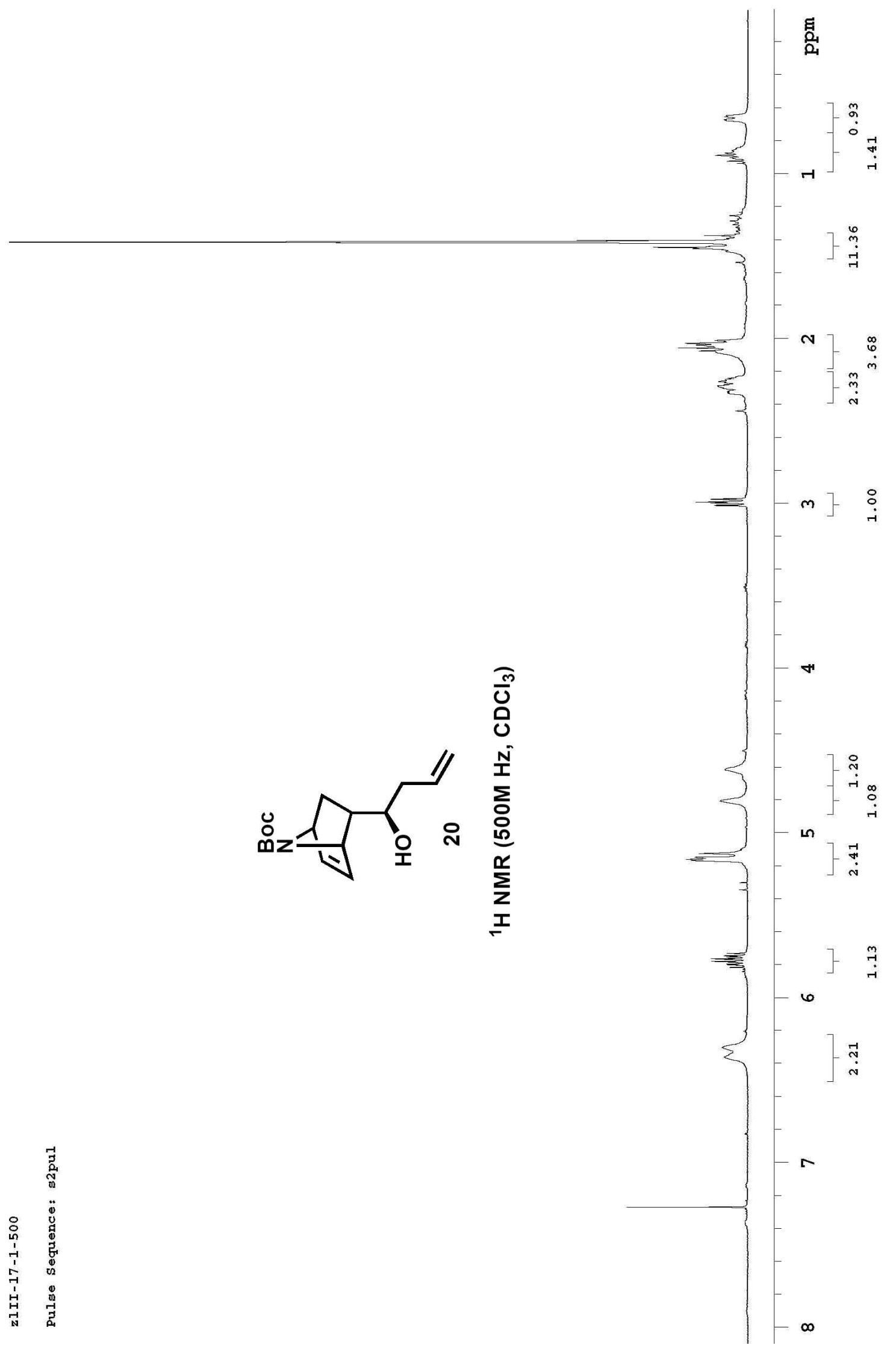




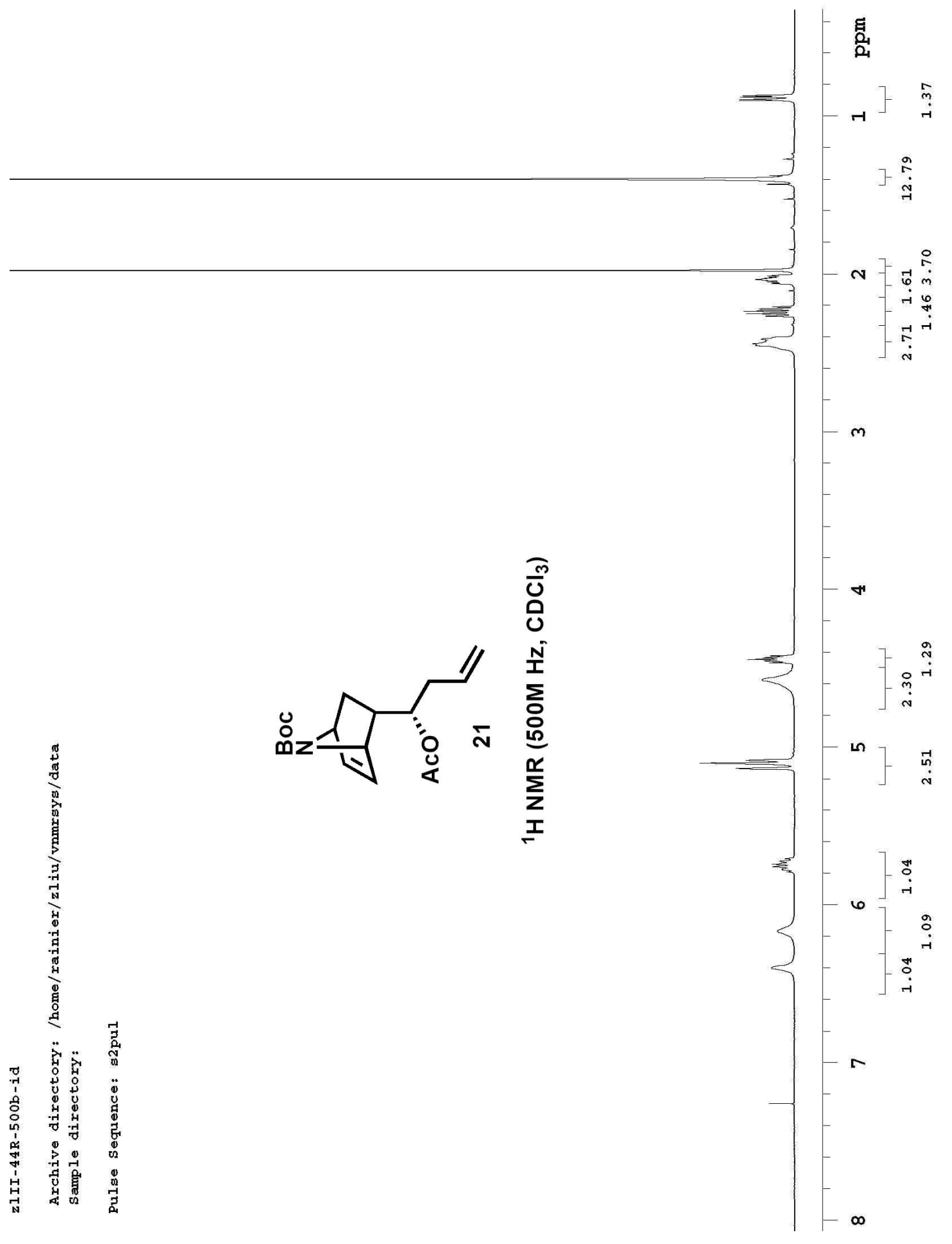




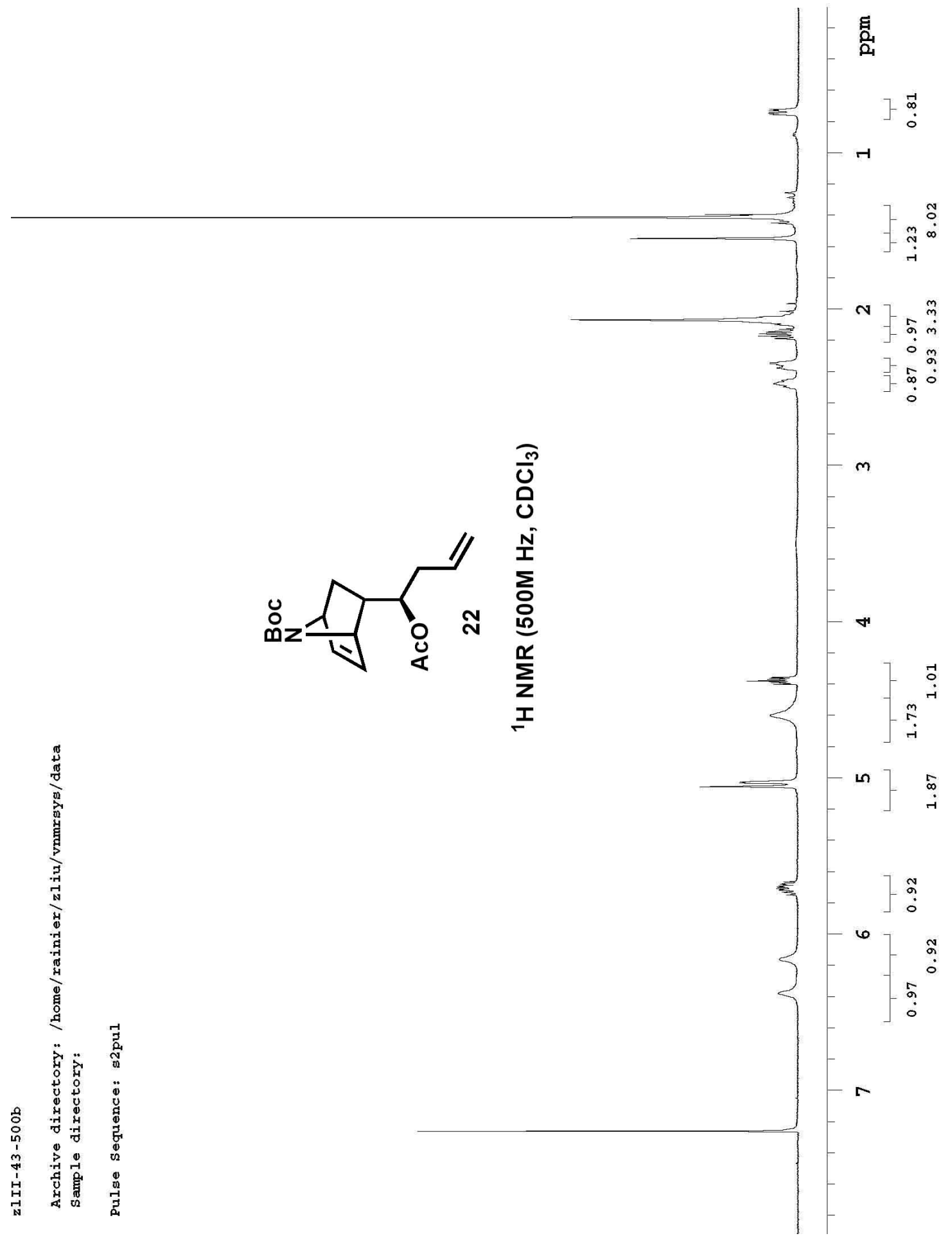




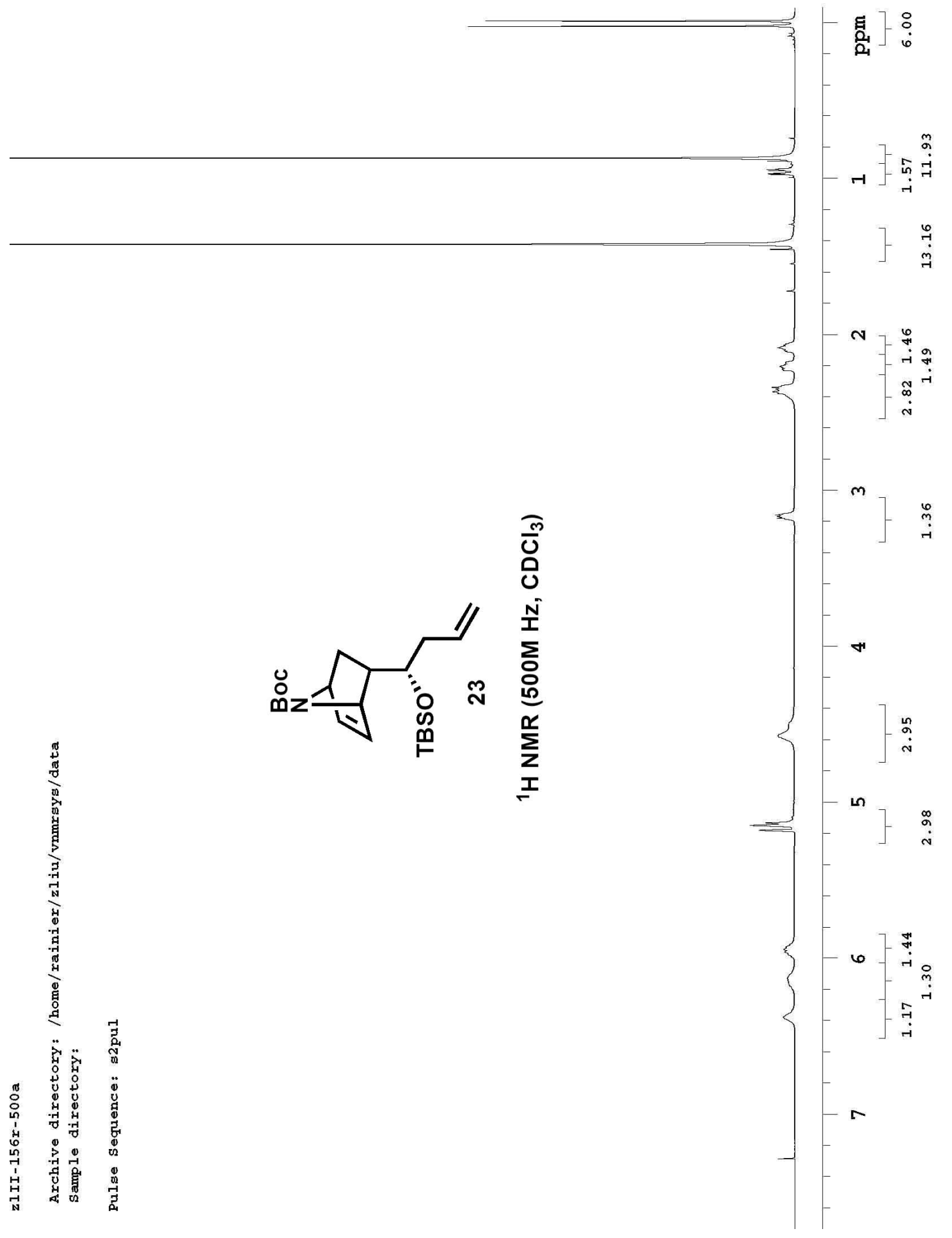




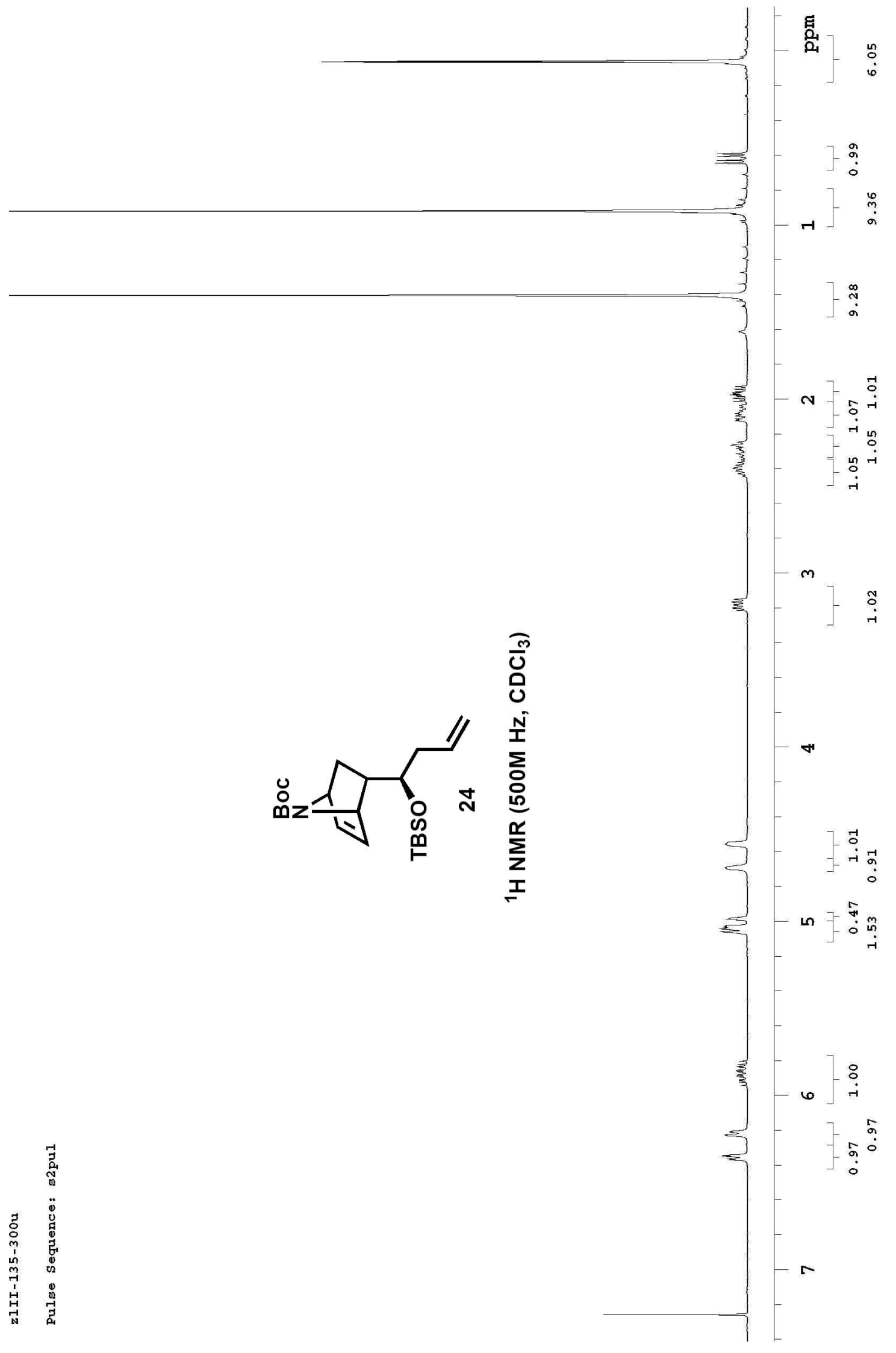




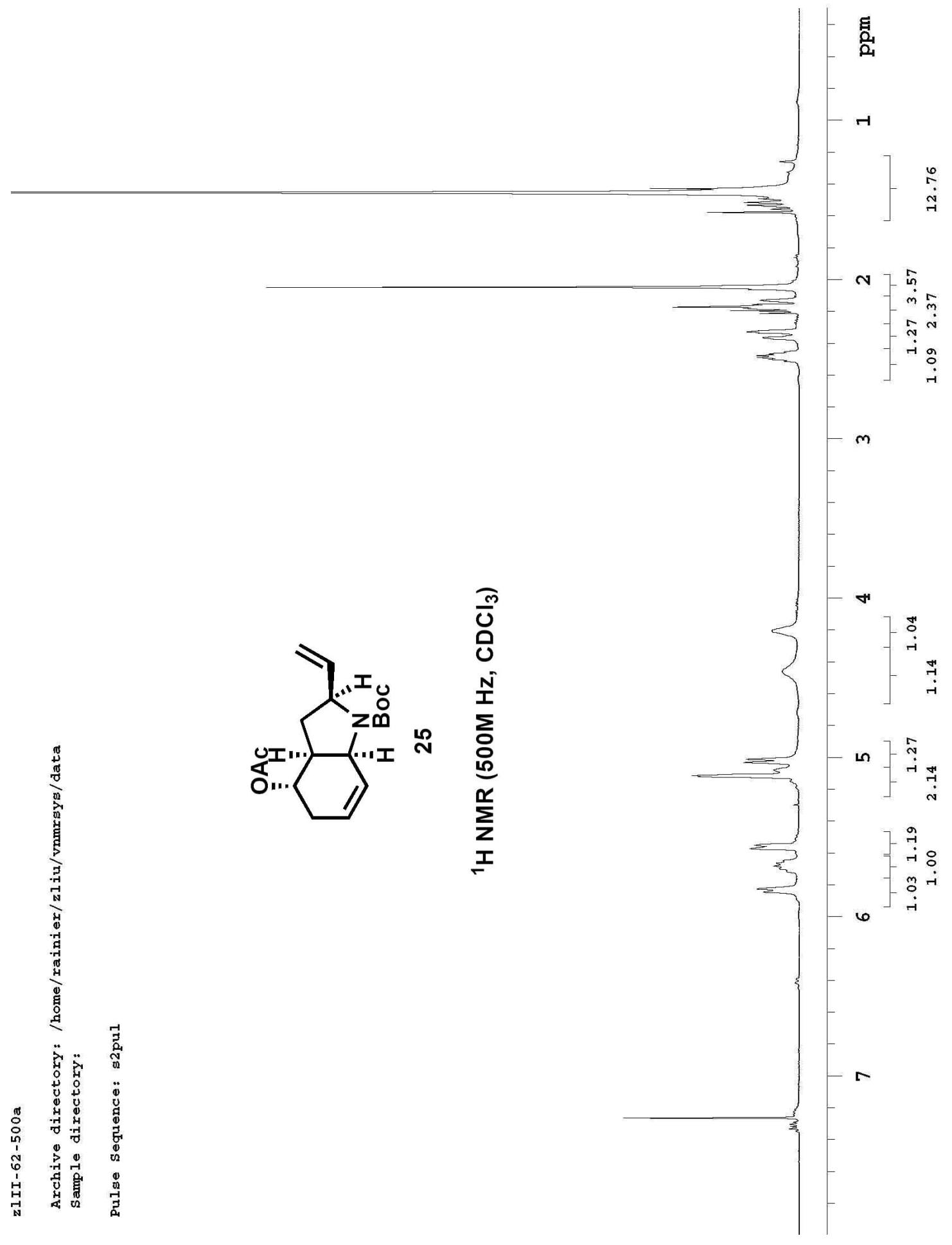




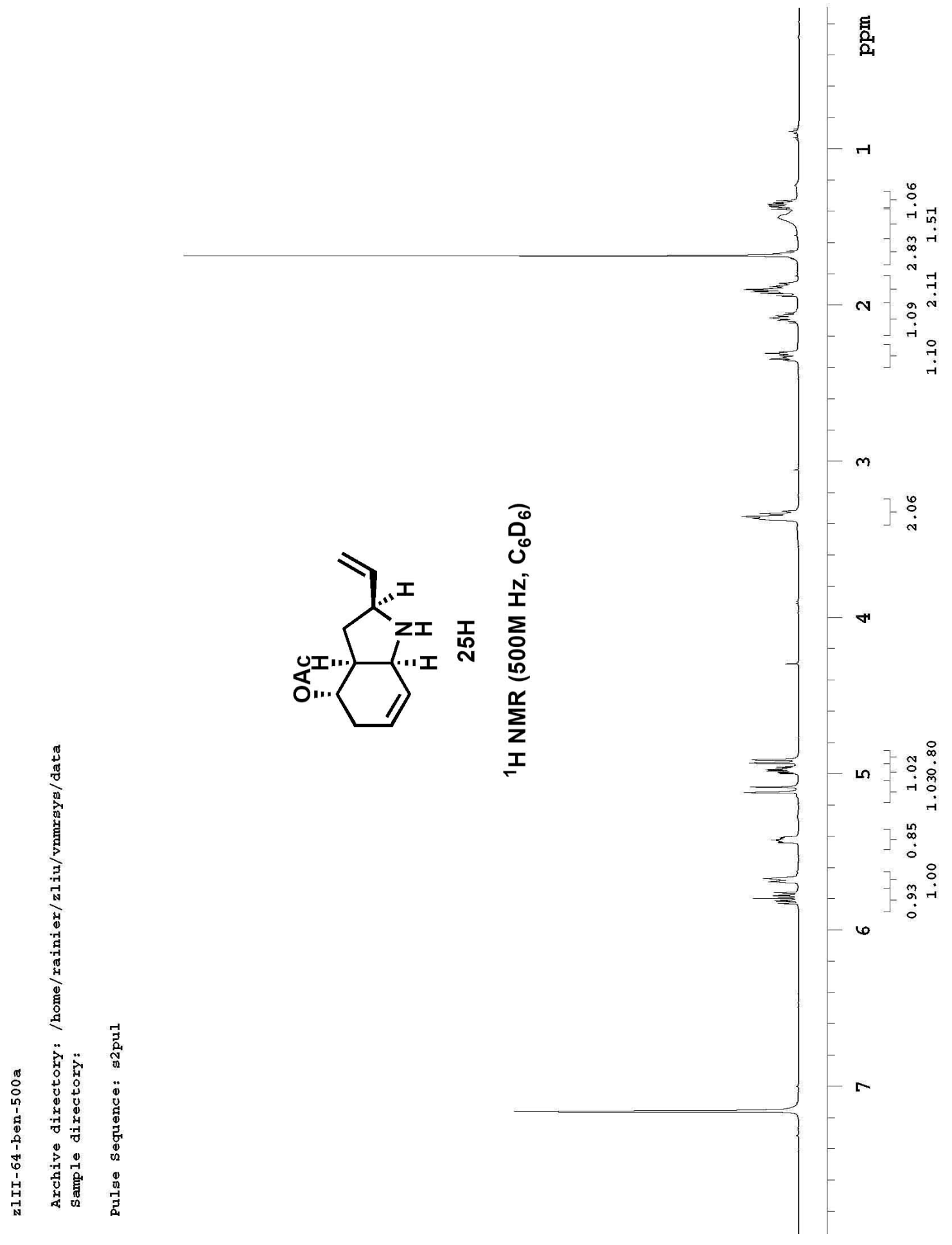




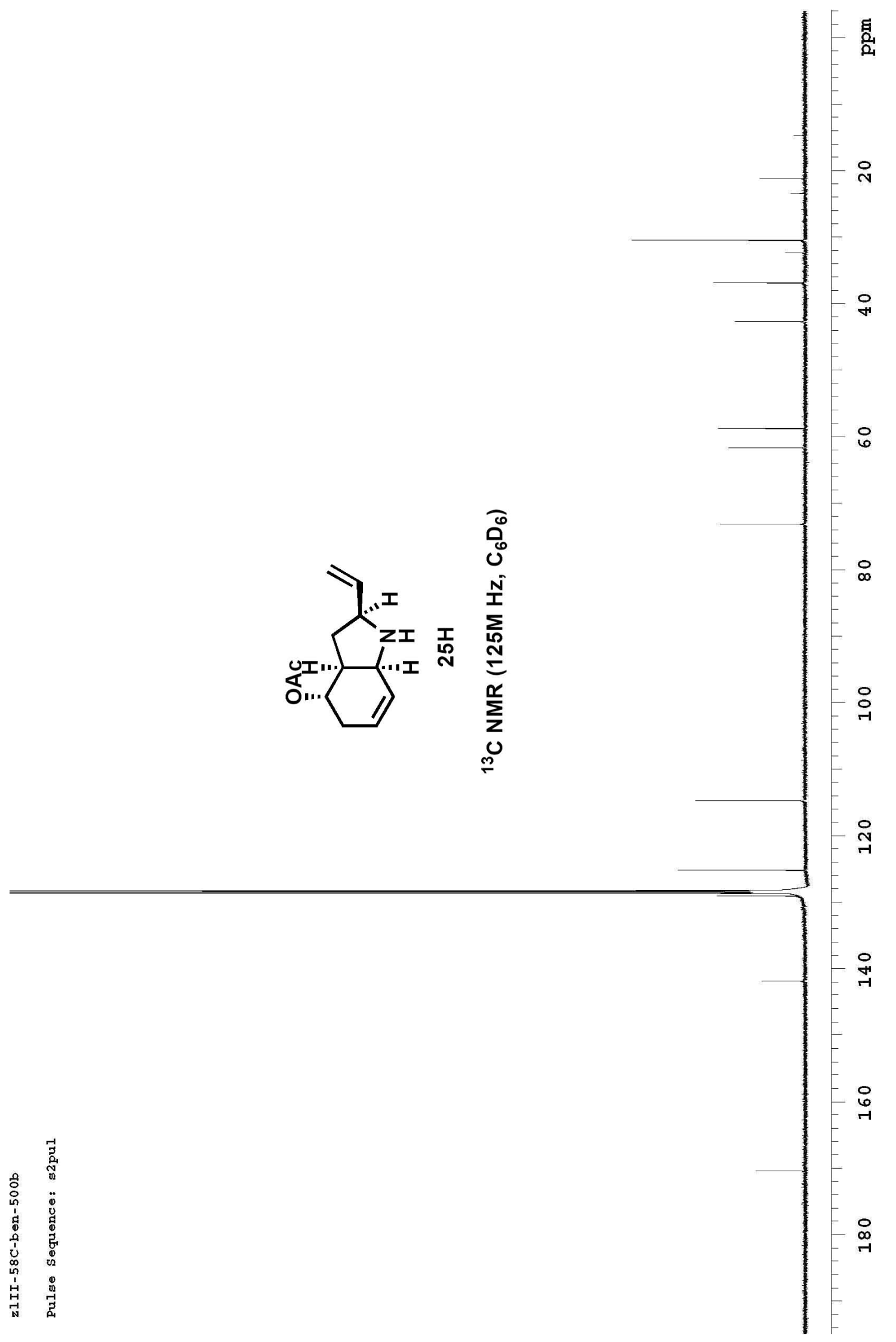



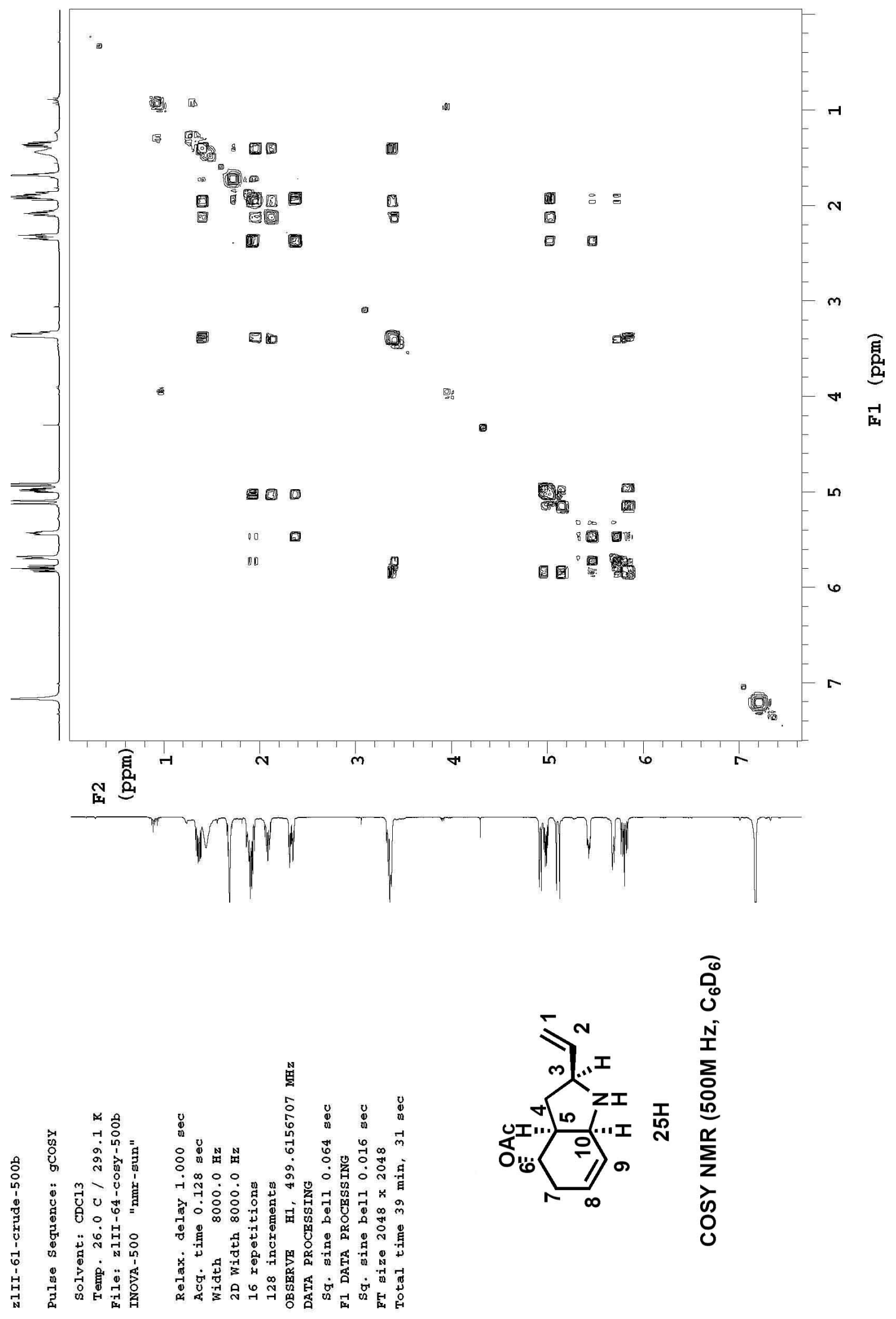


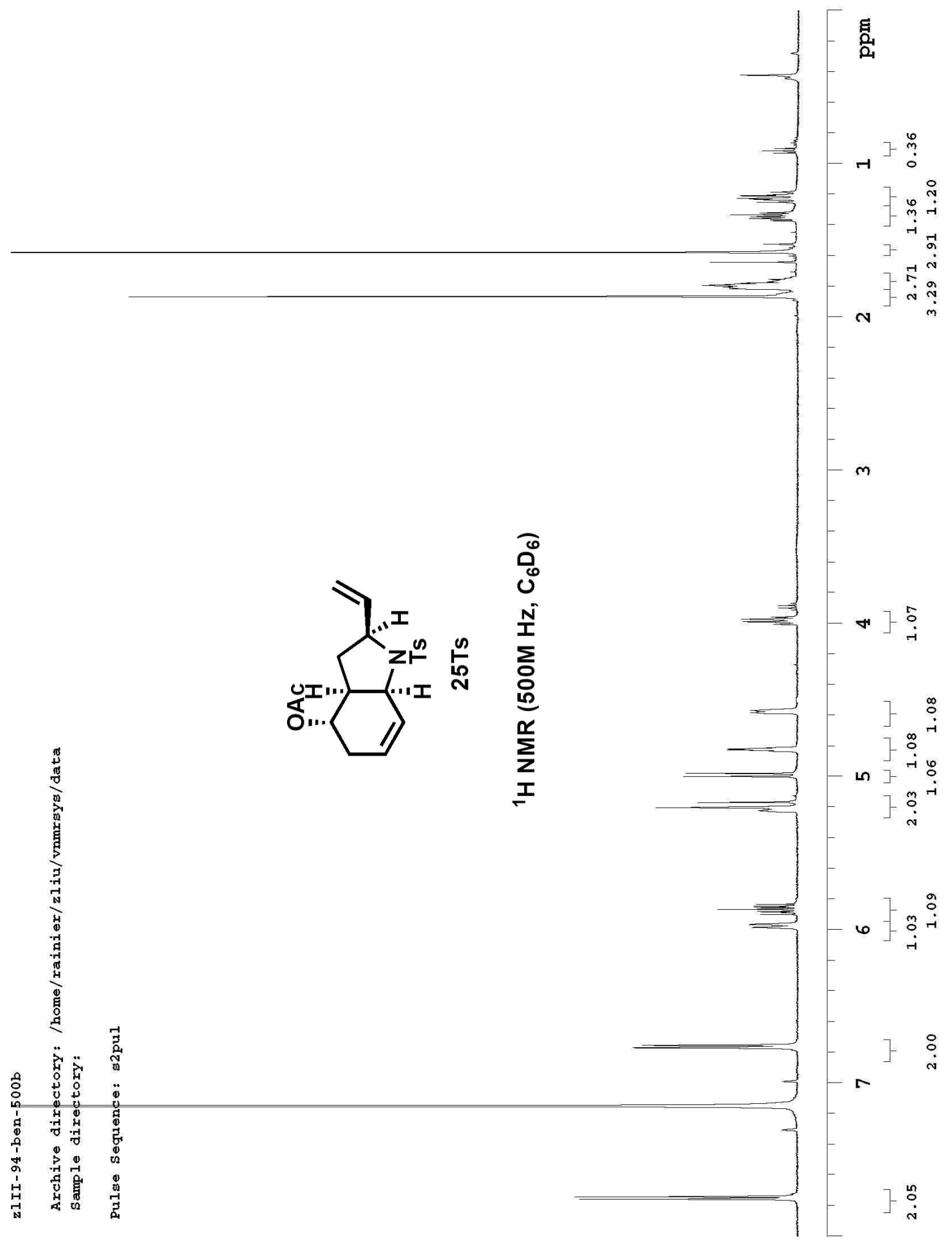




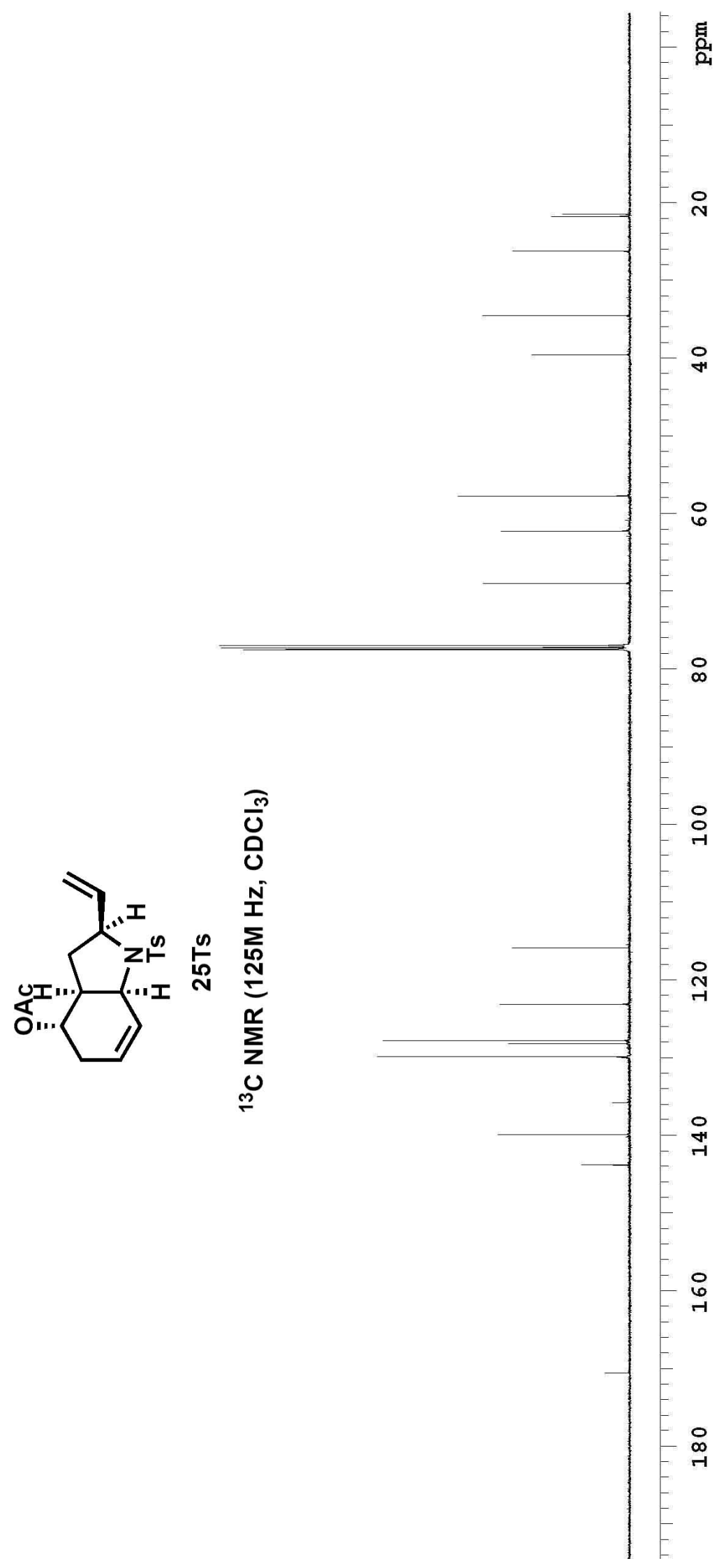




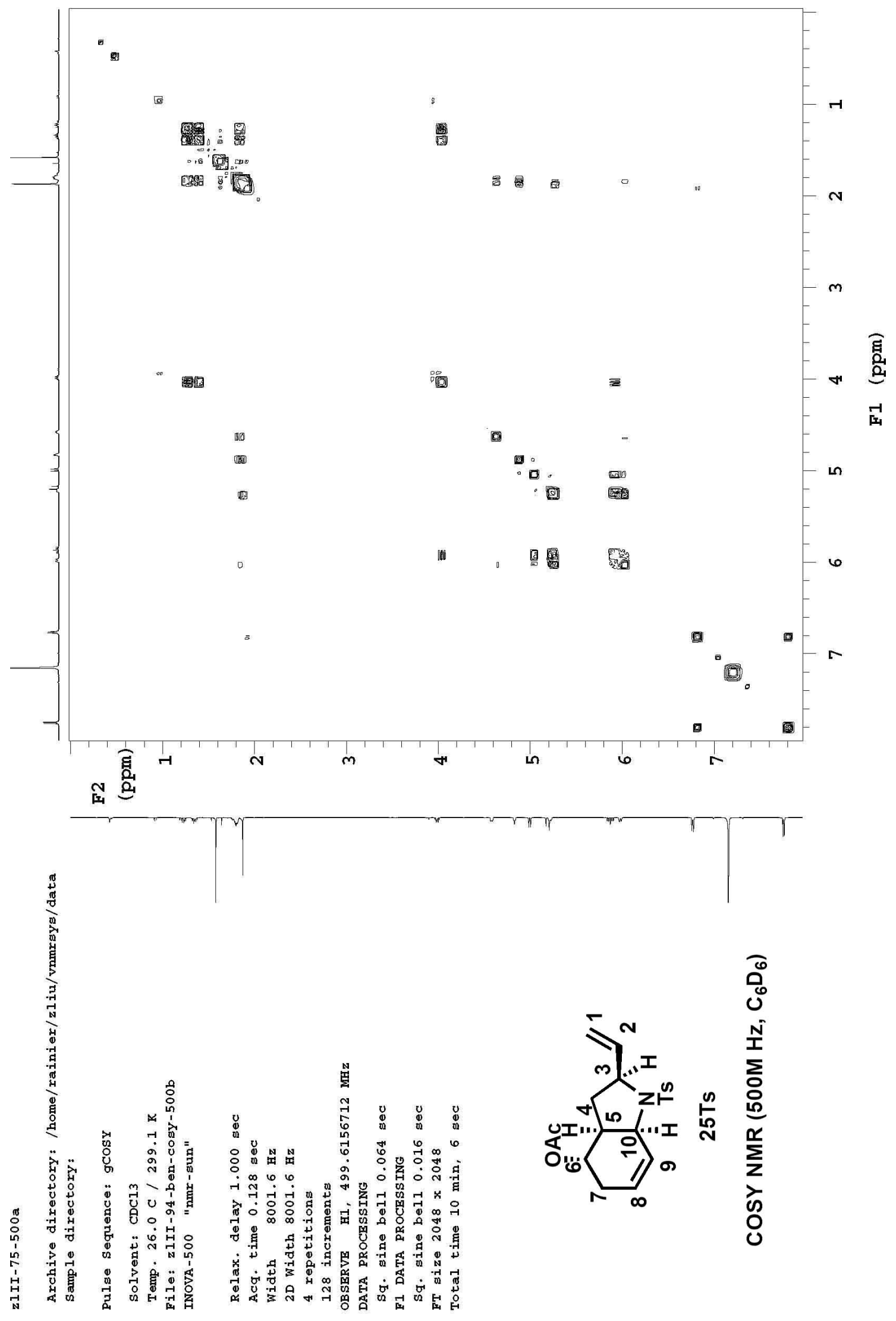




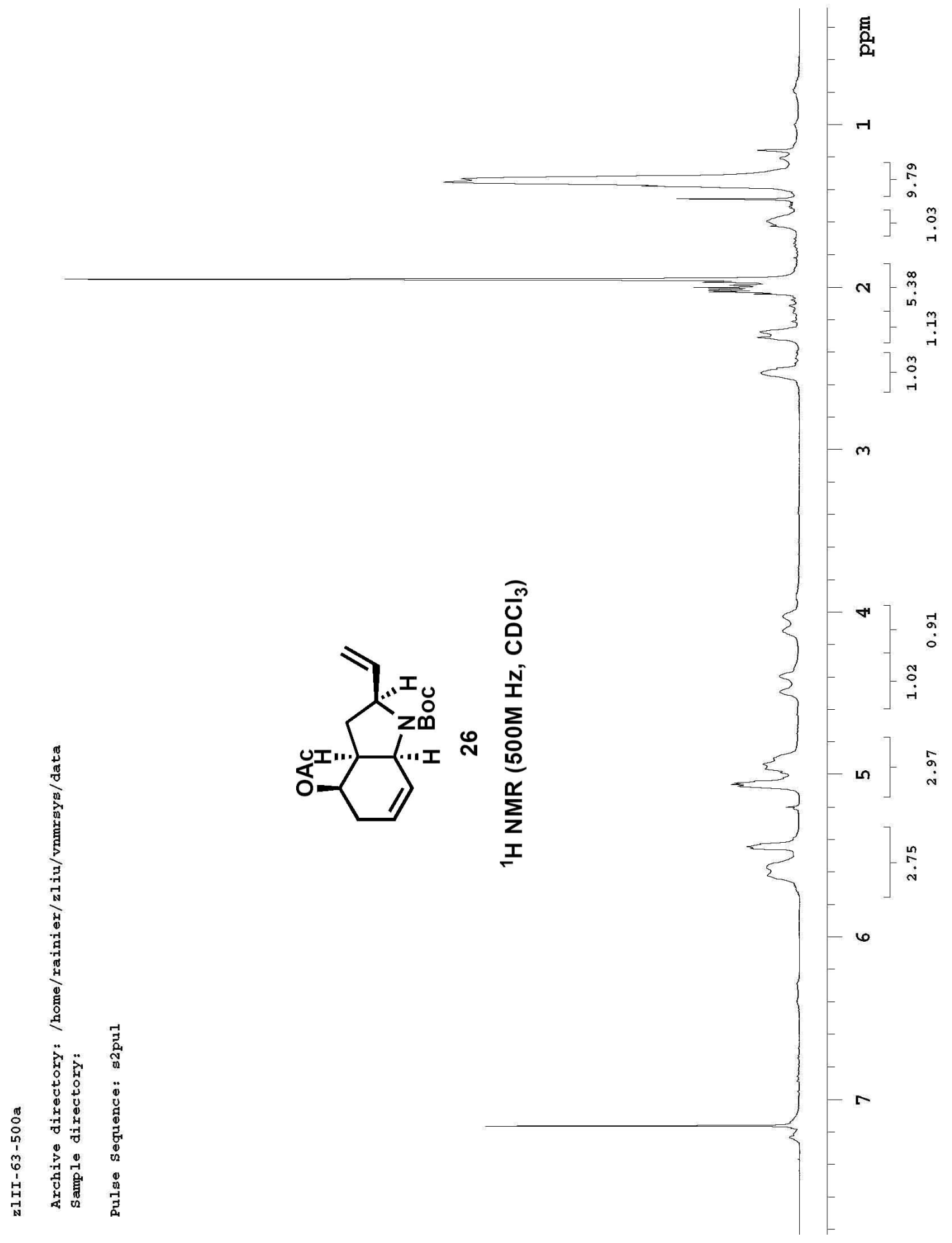




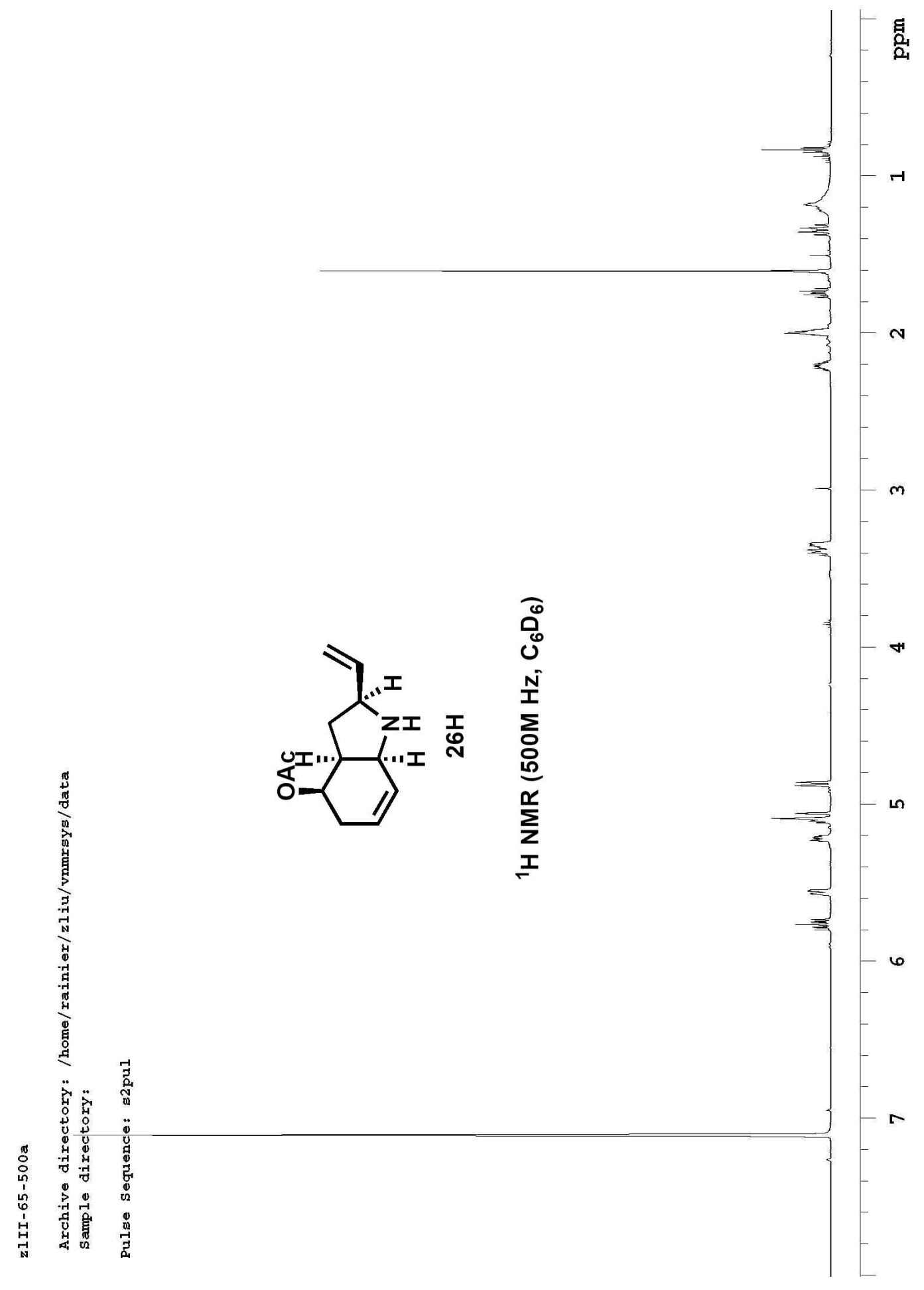




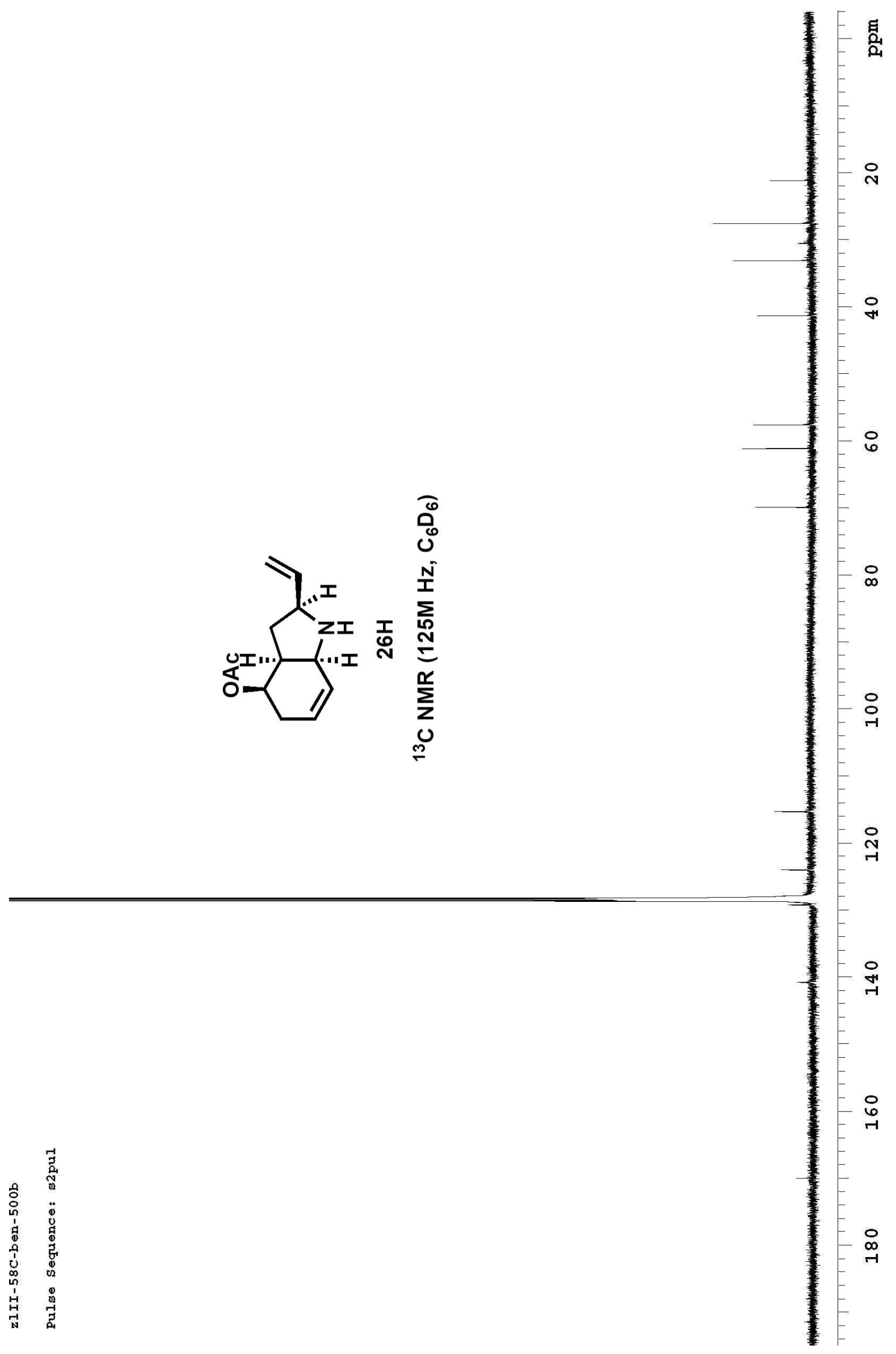



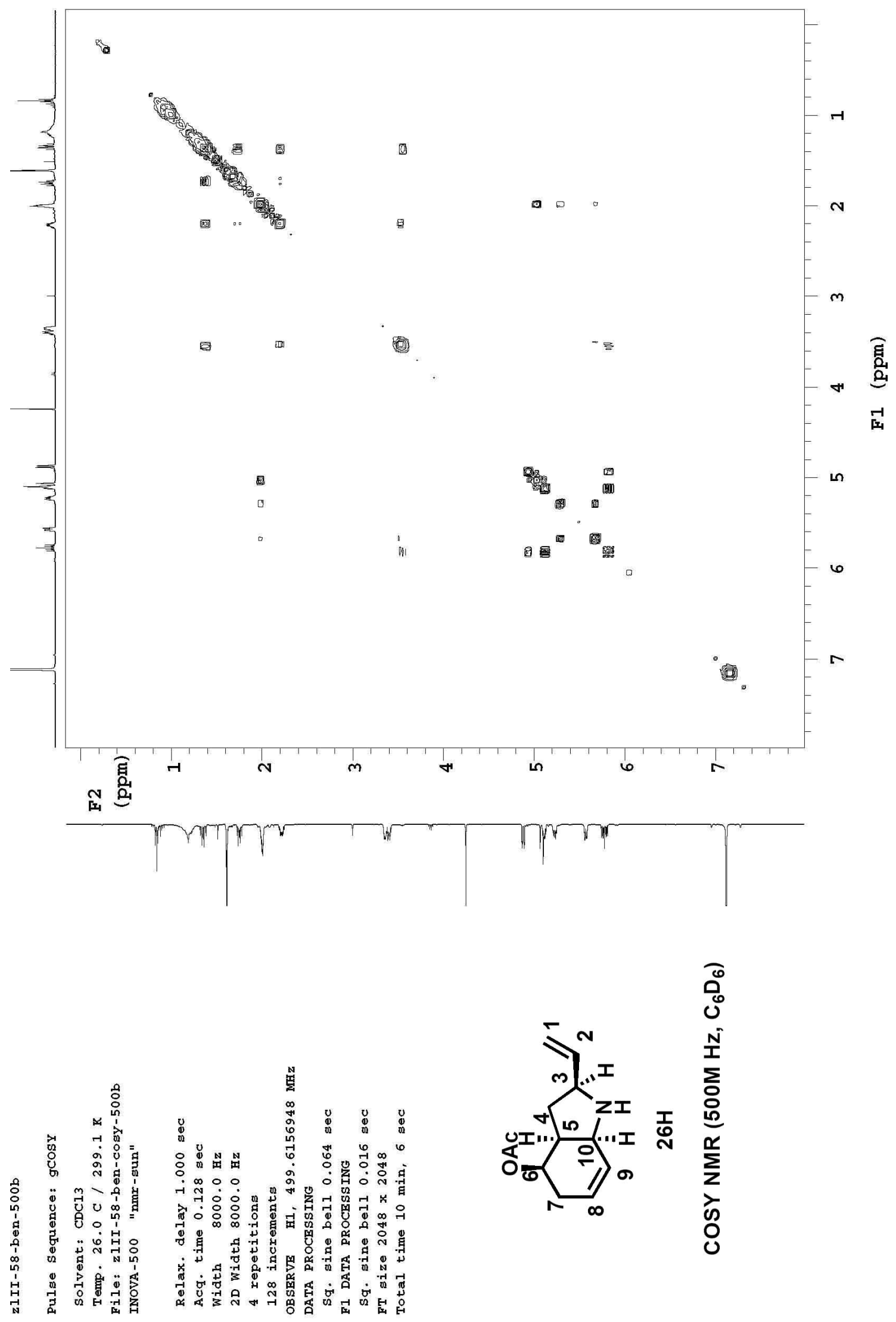


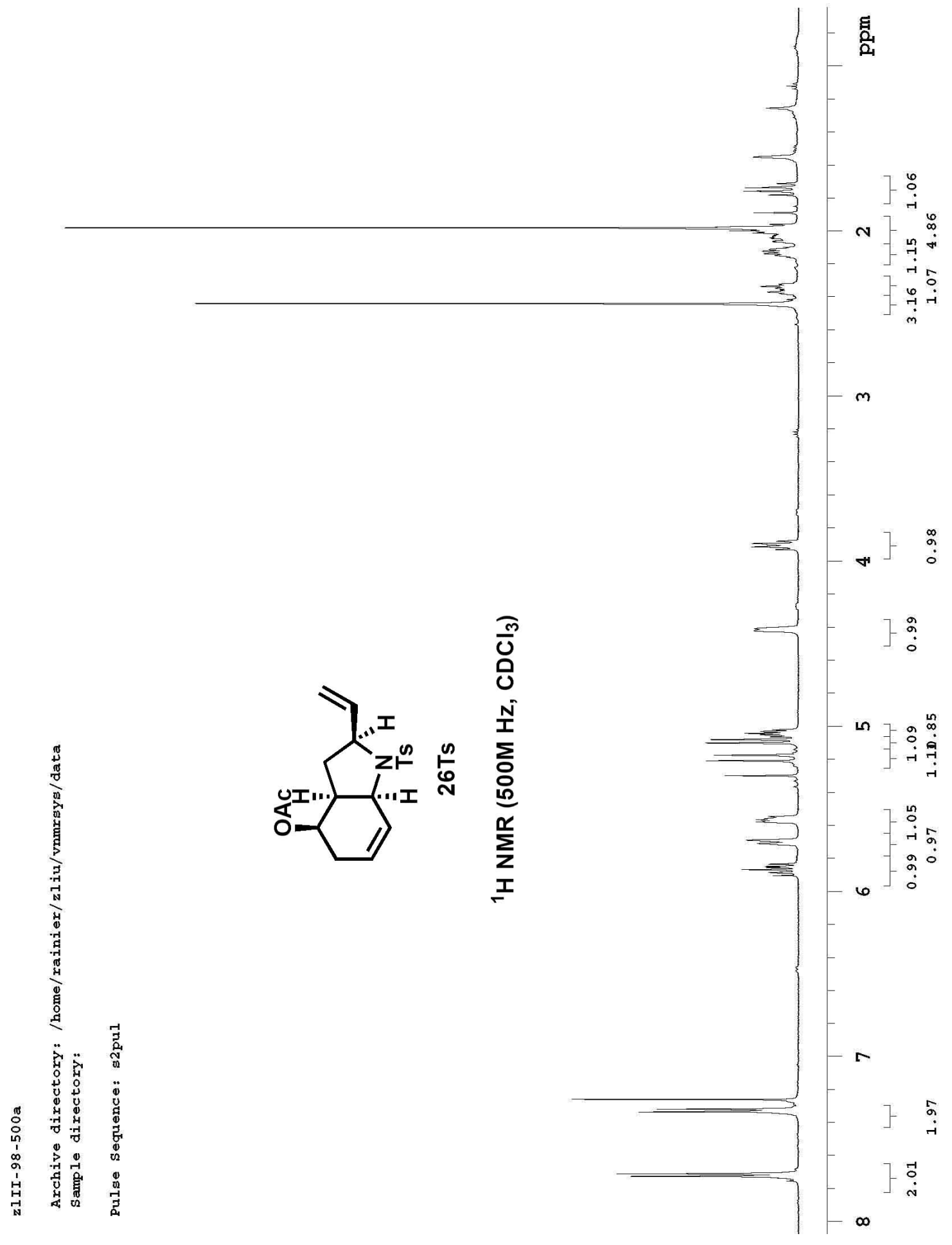




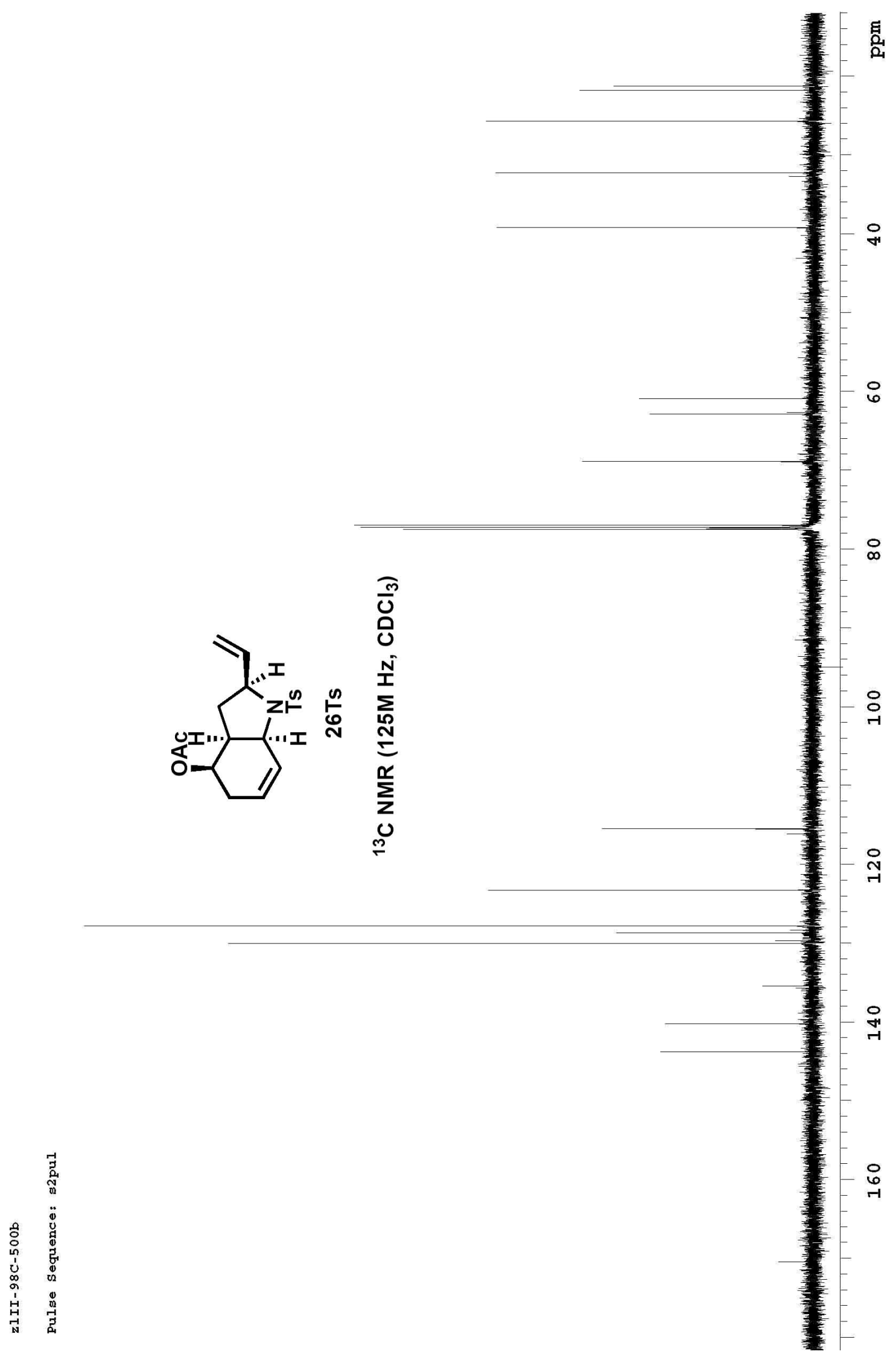




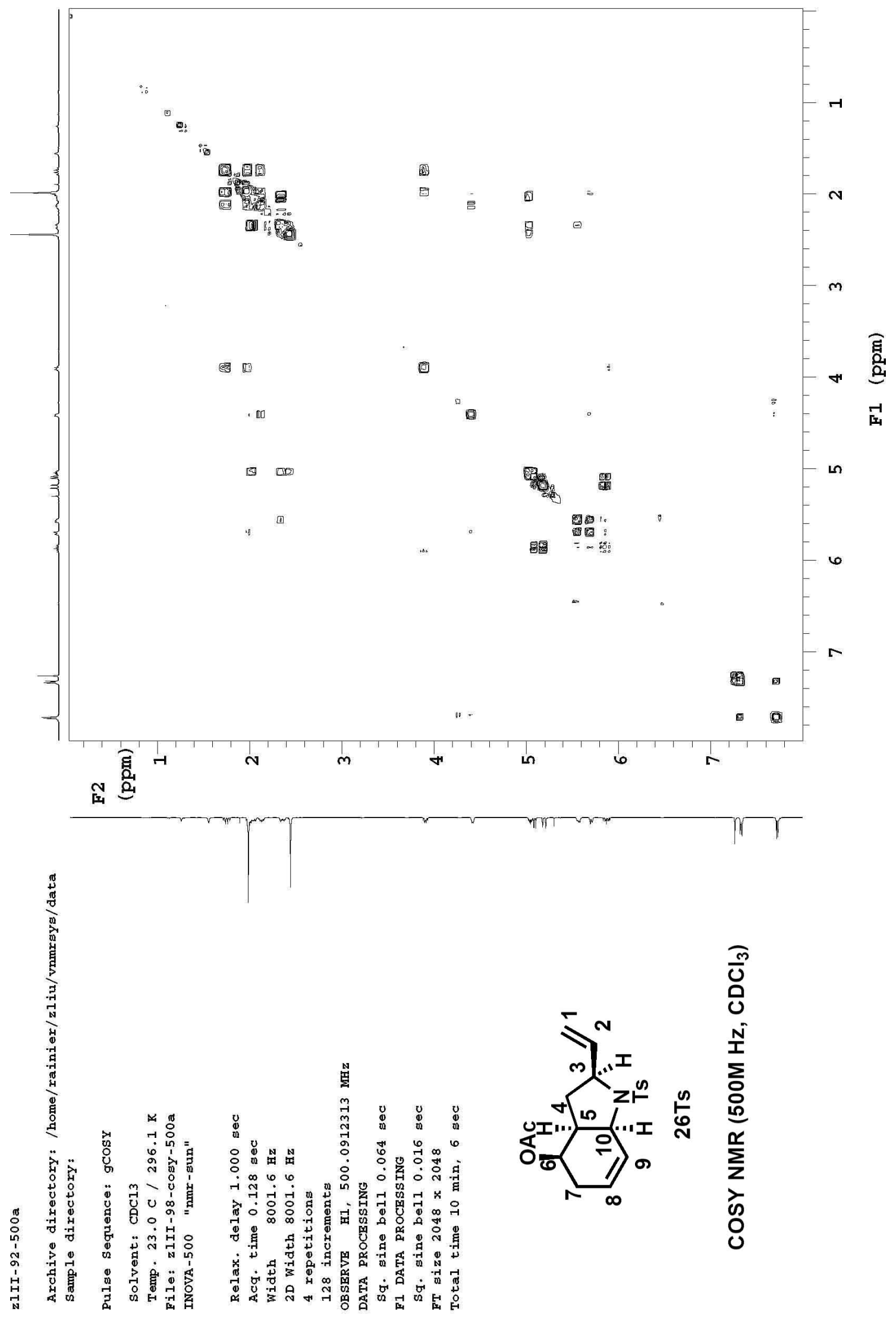




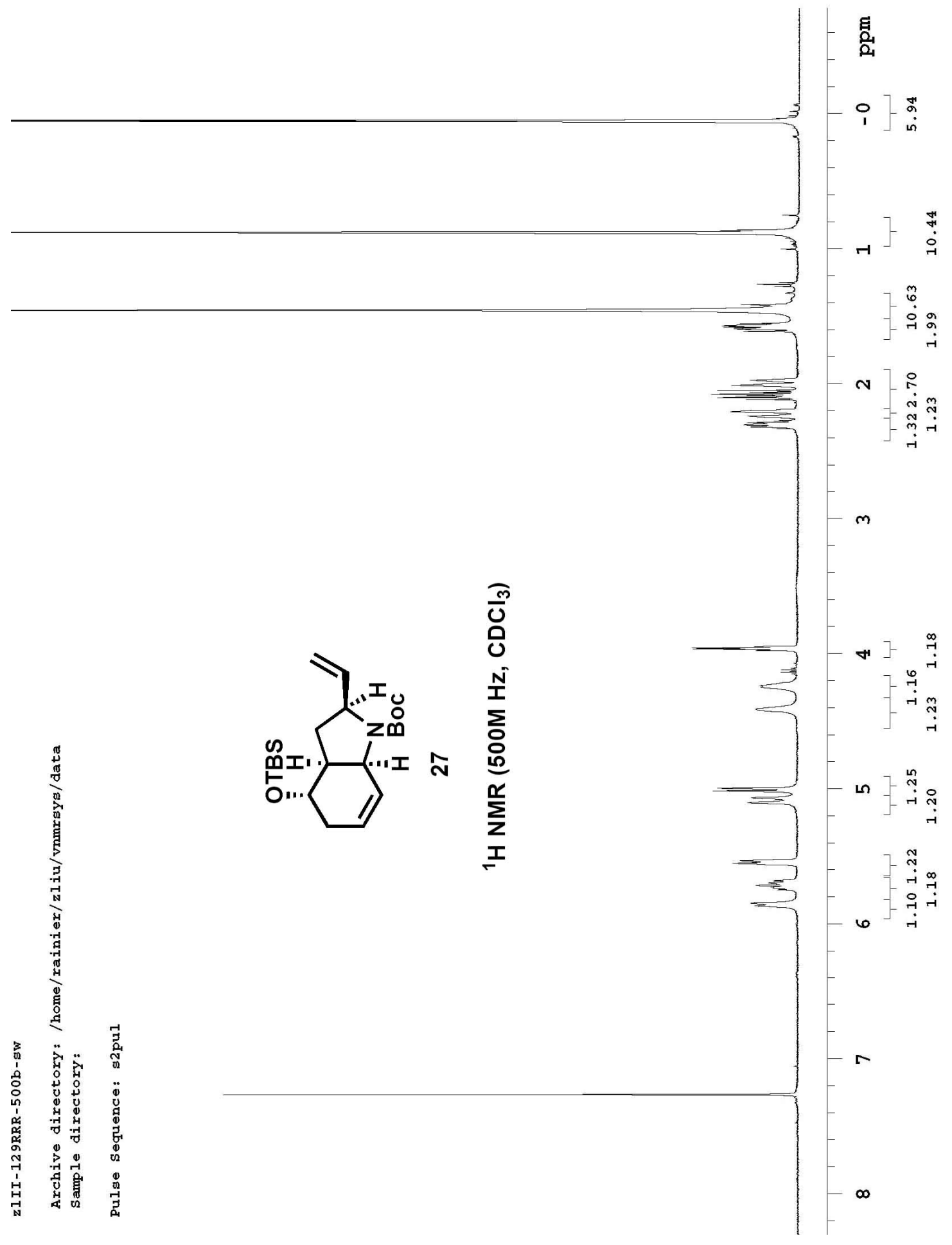




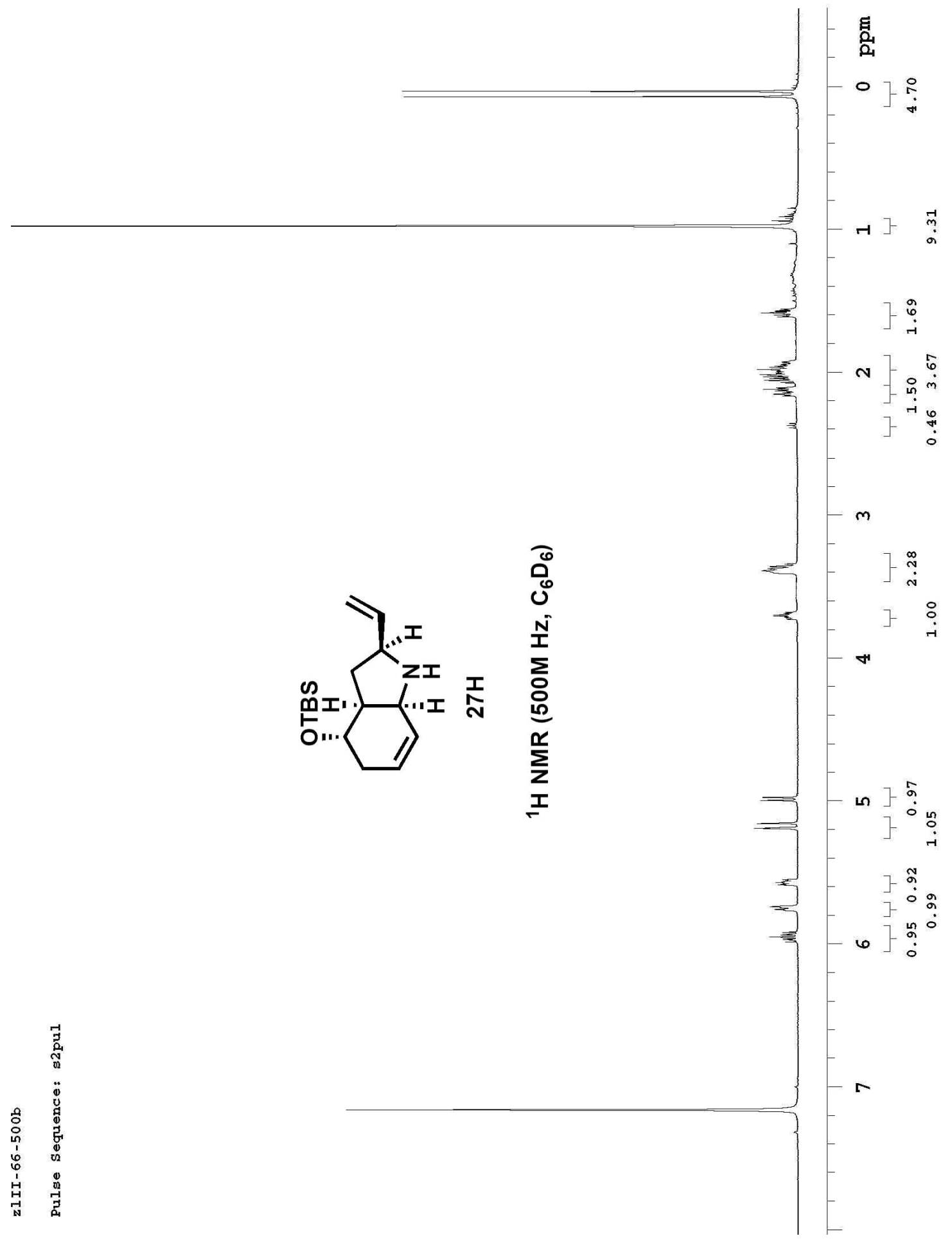




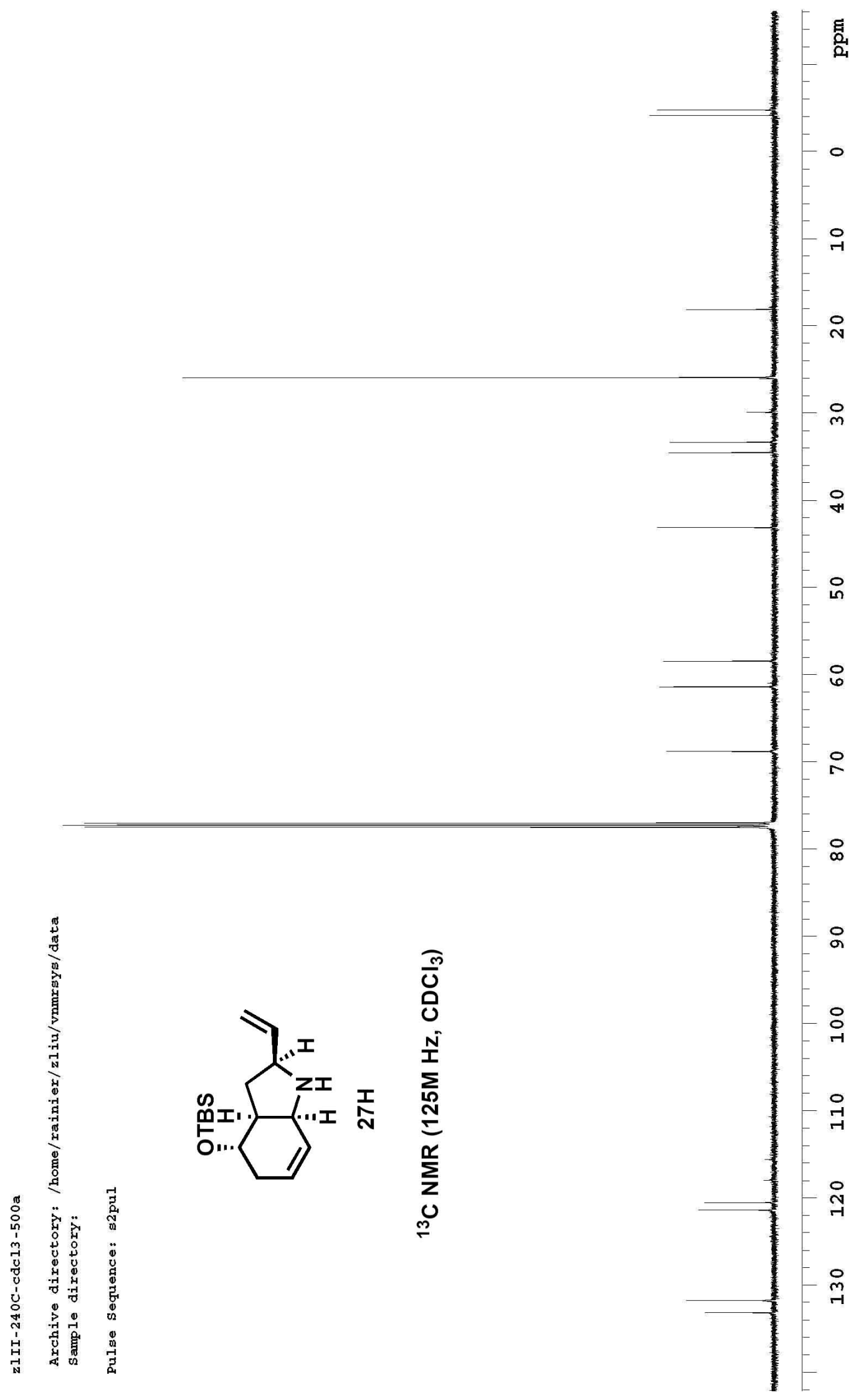



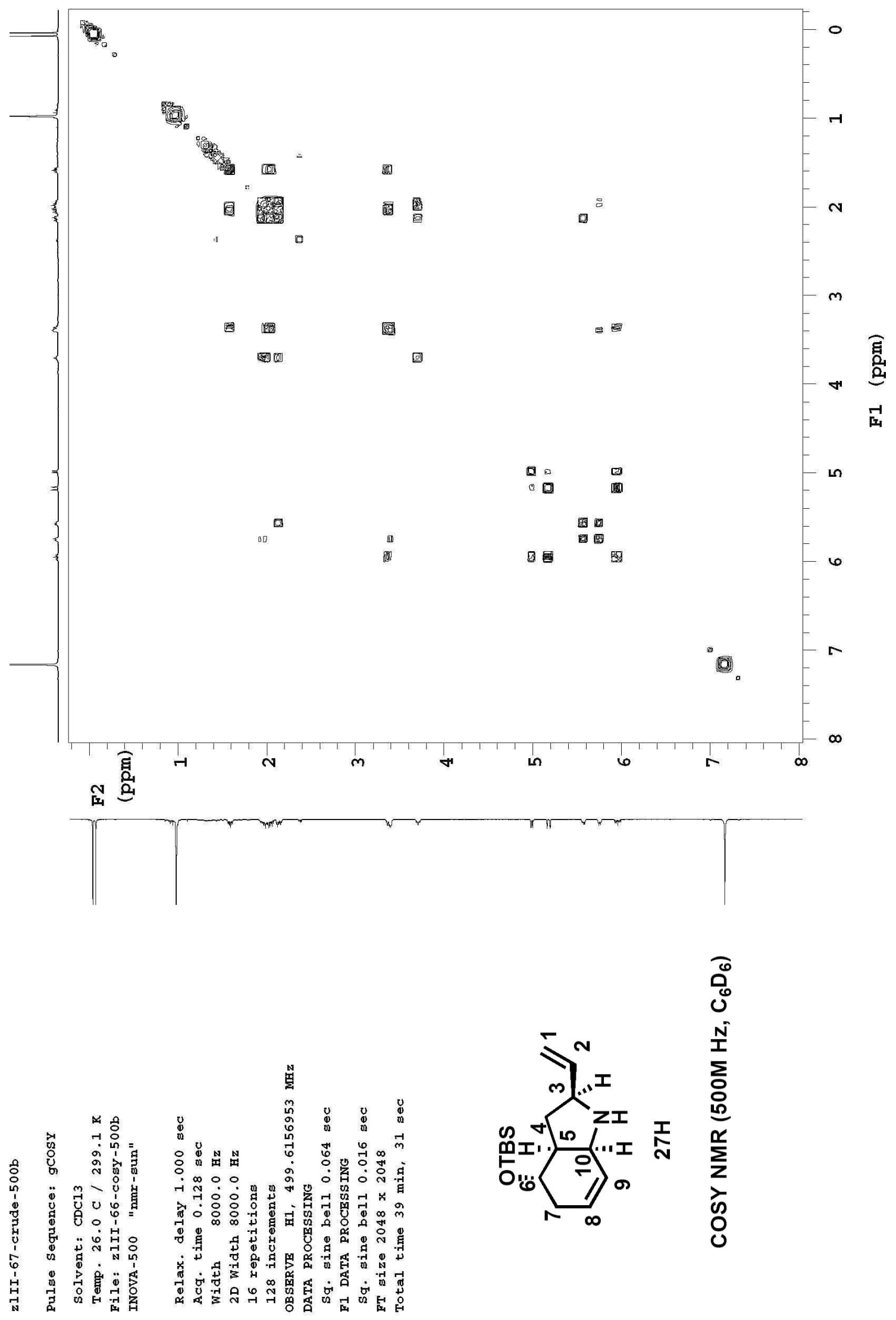


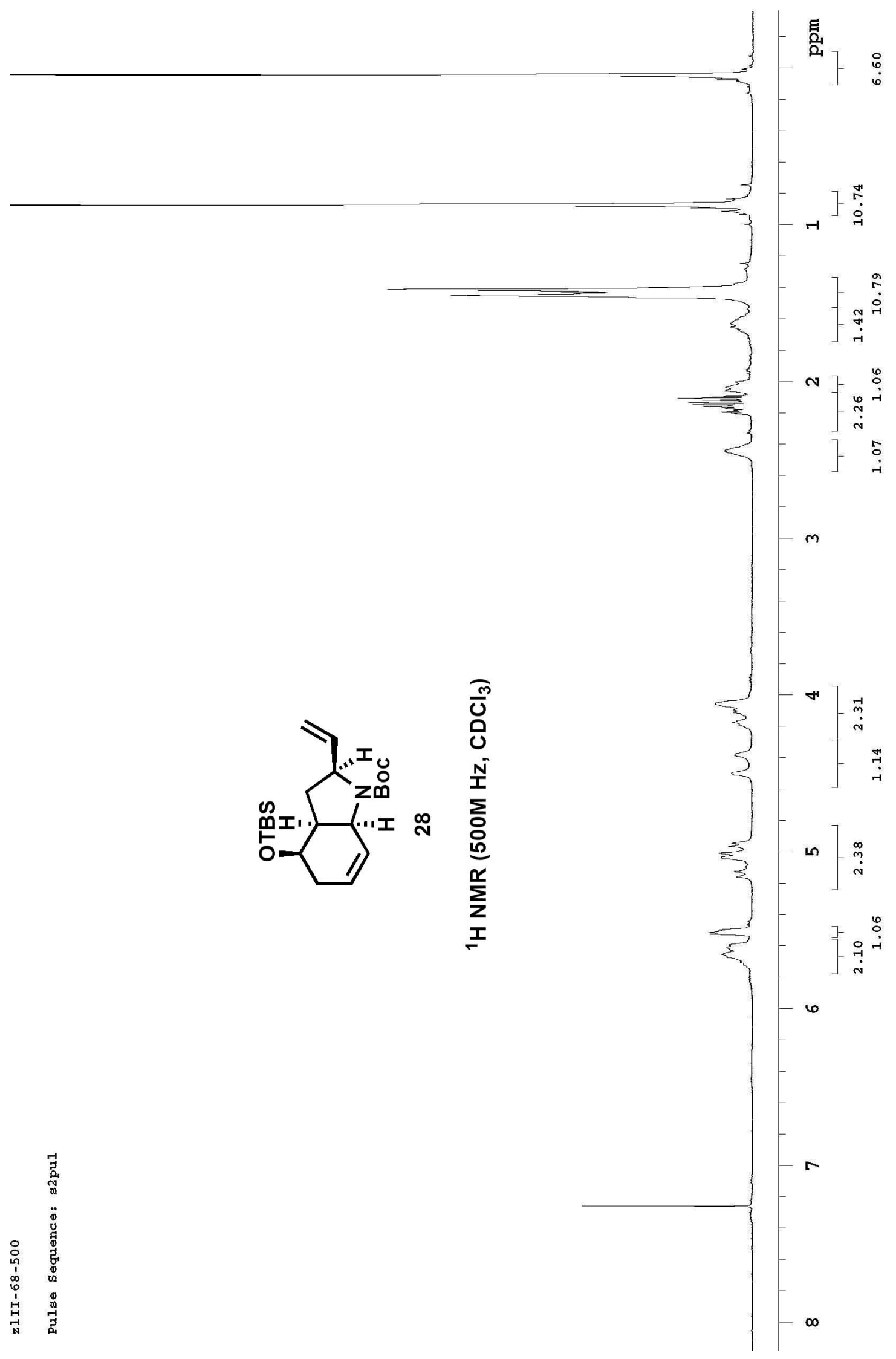




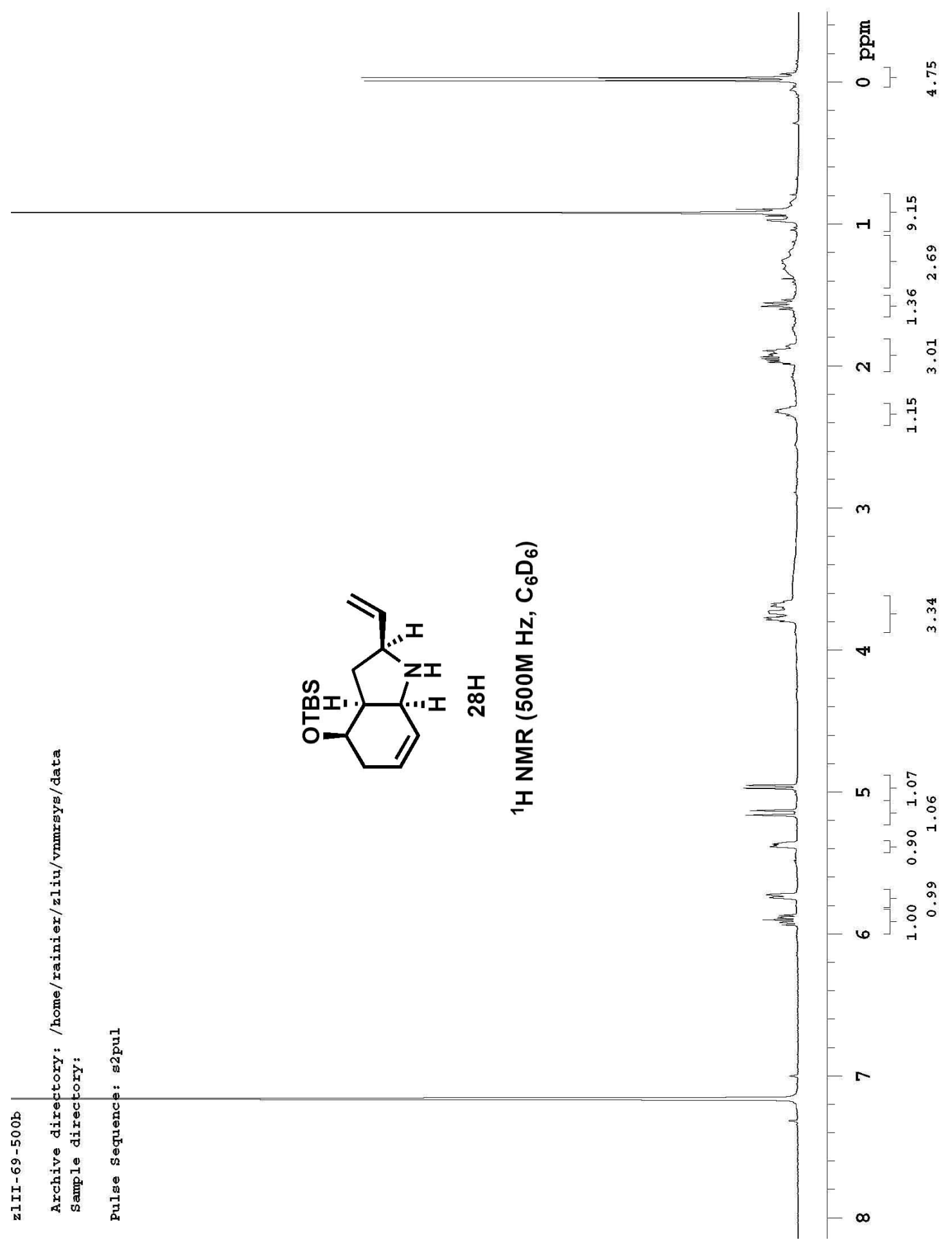




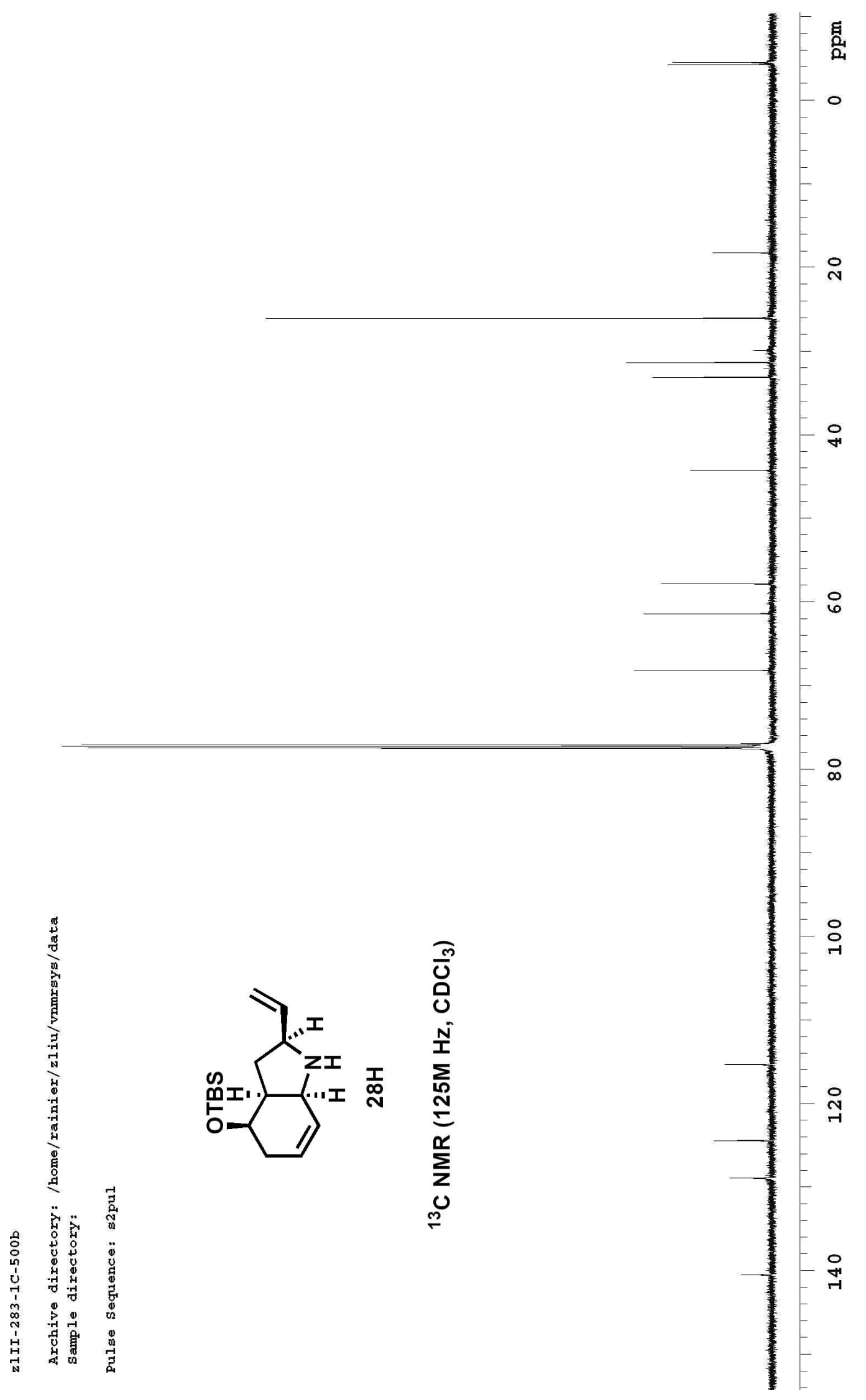




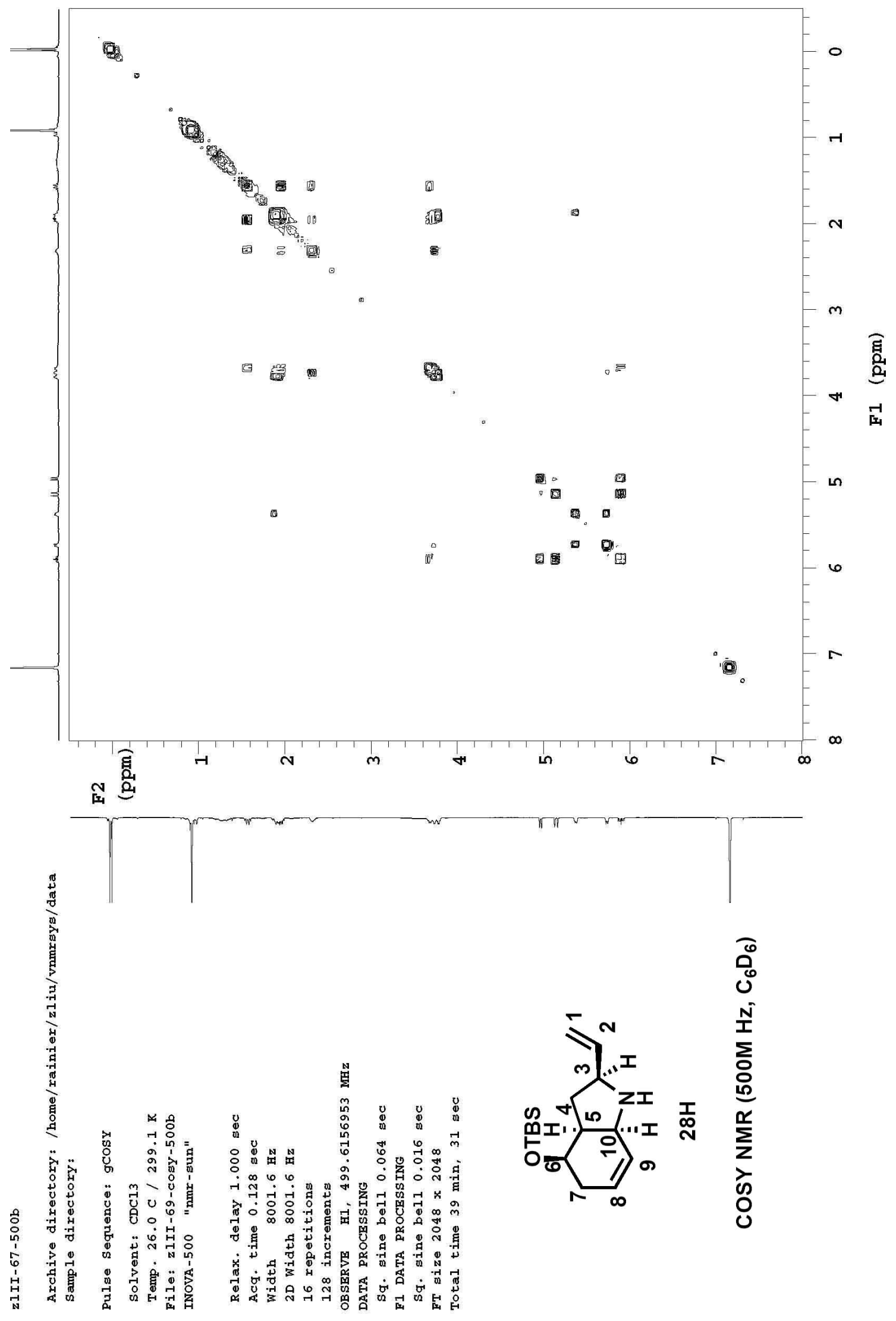




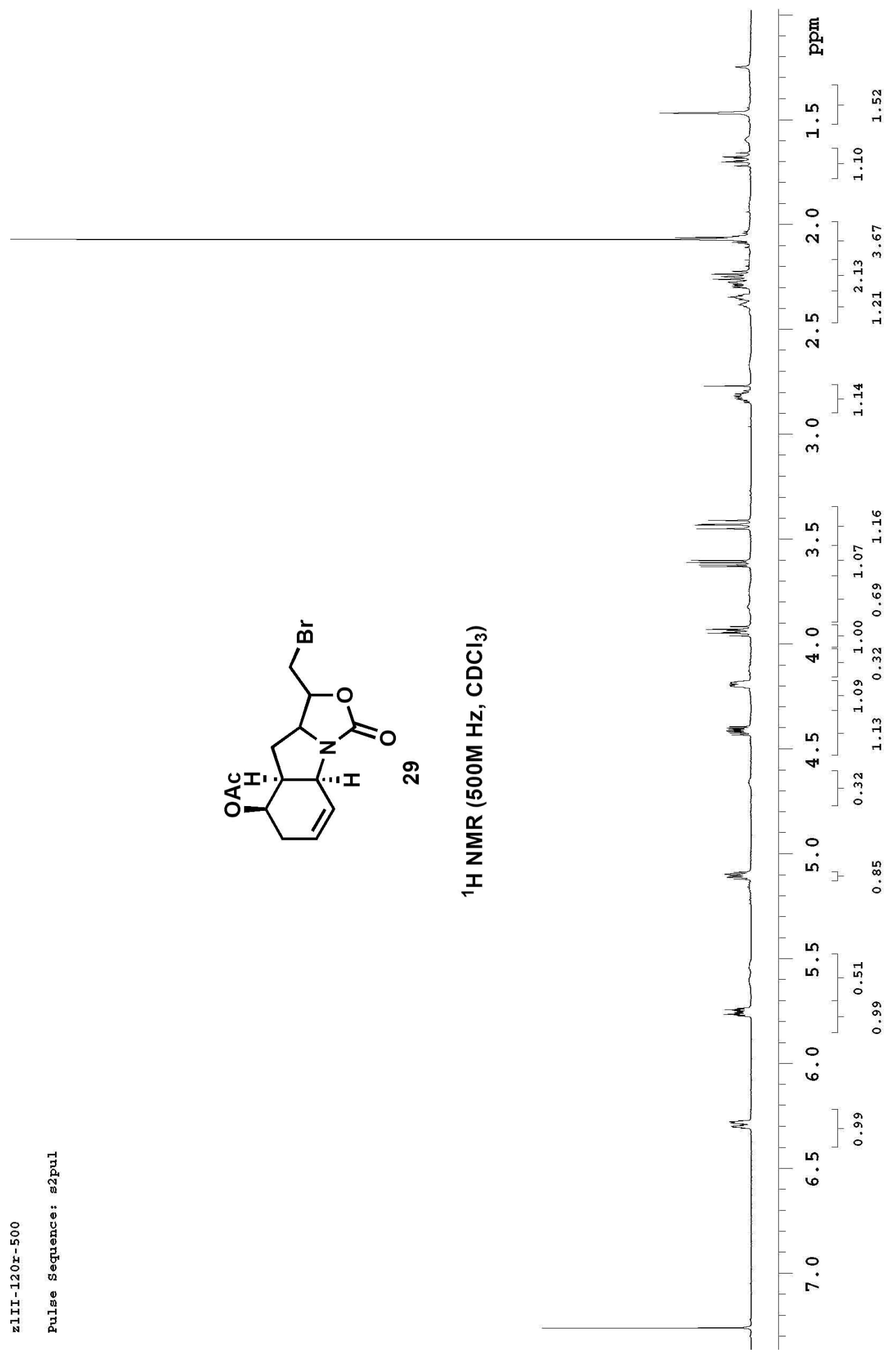




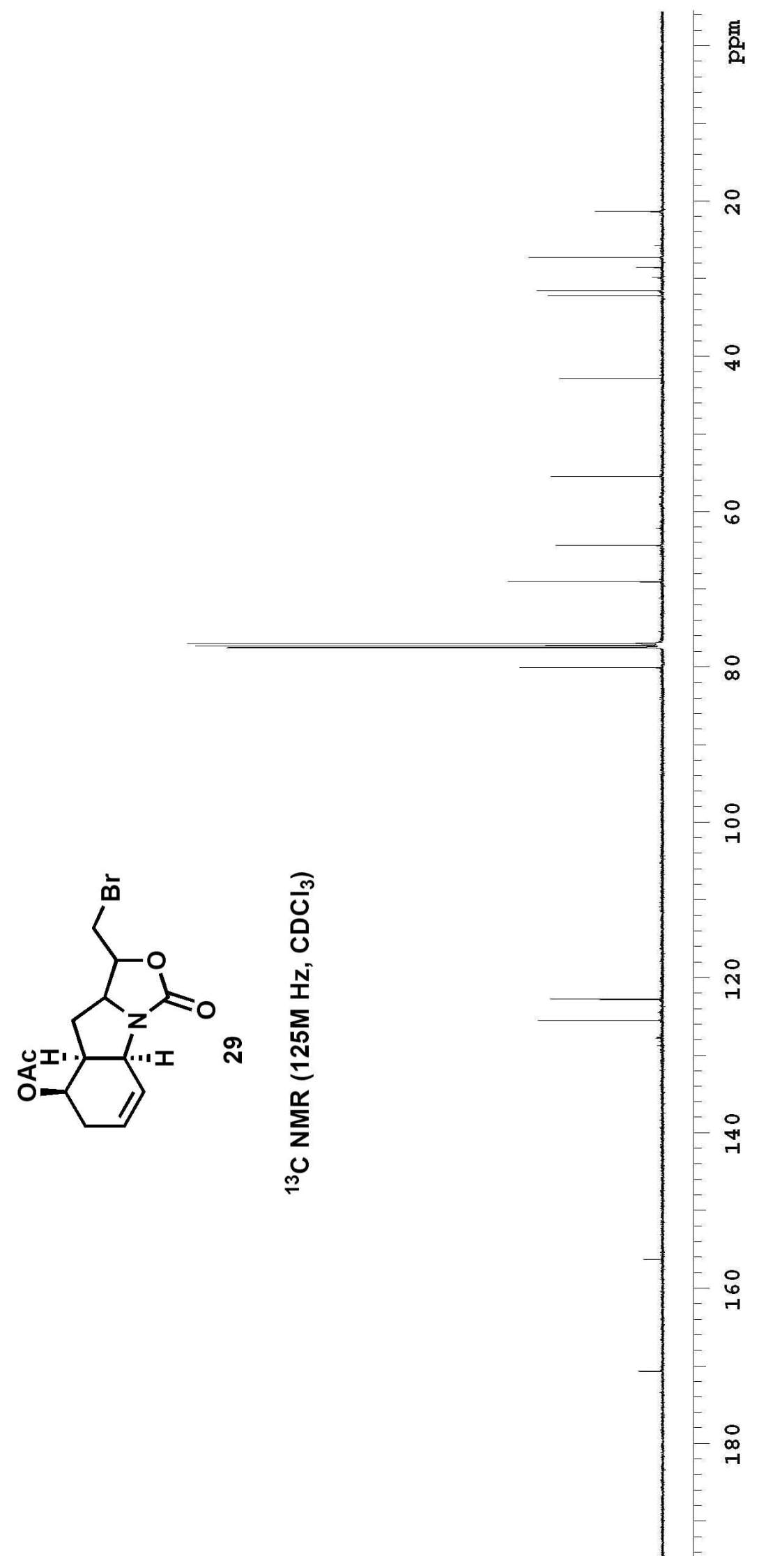




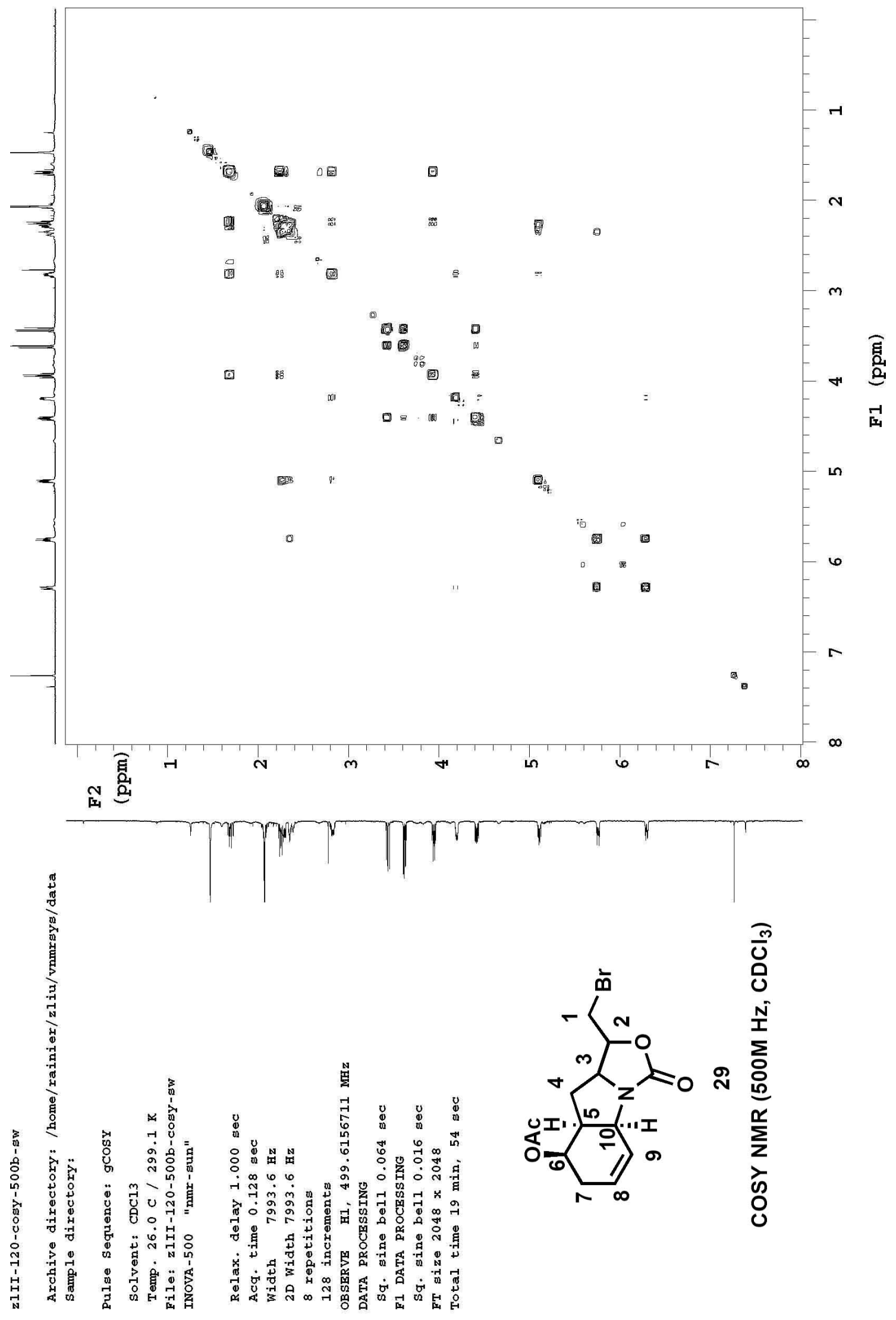




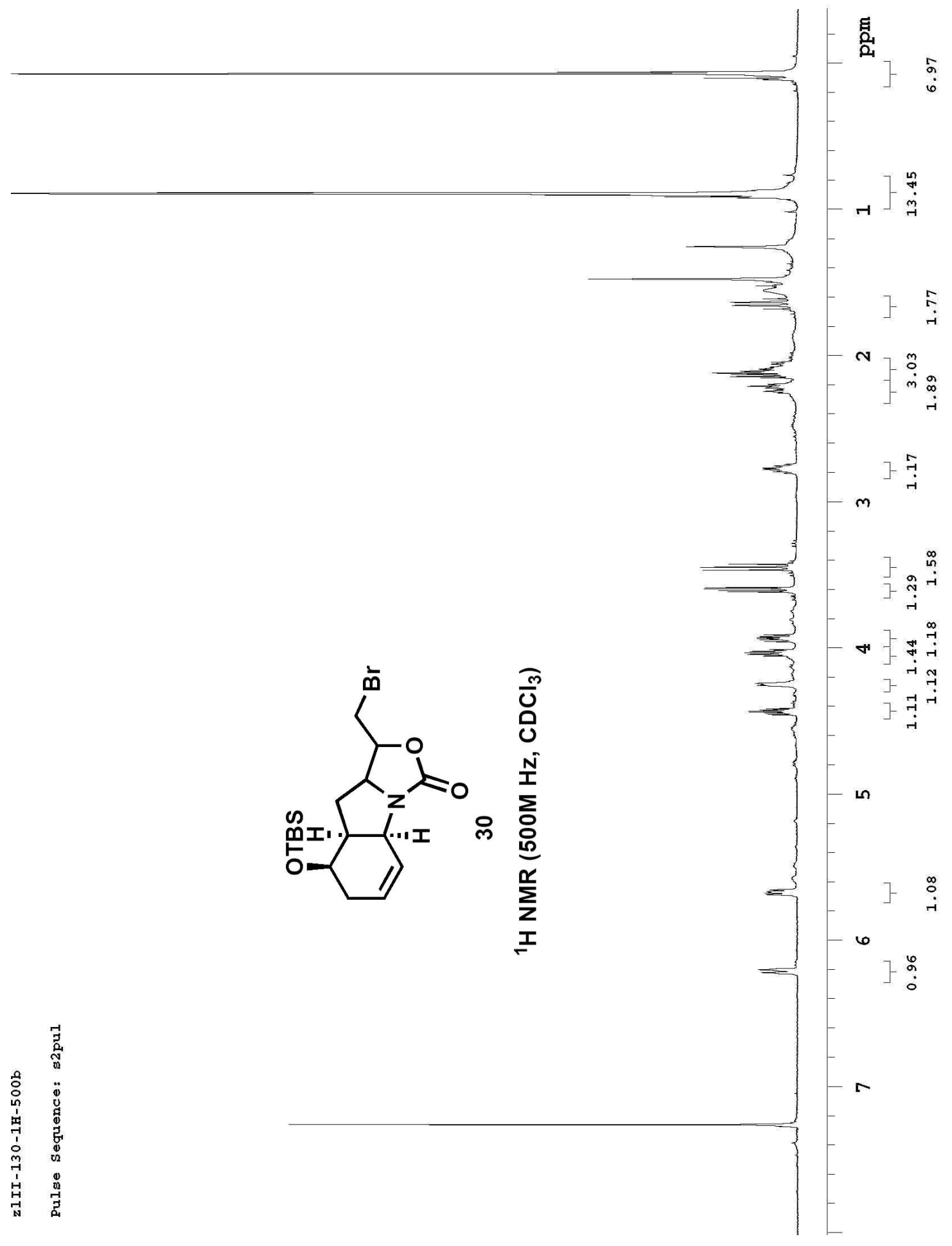




$$
\text { al }
$$



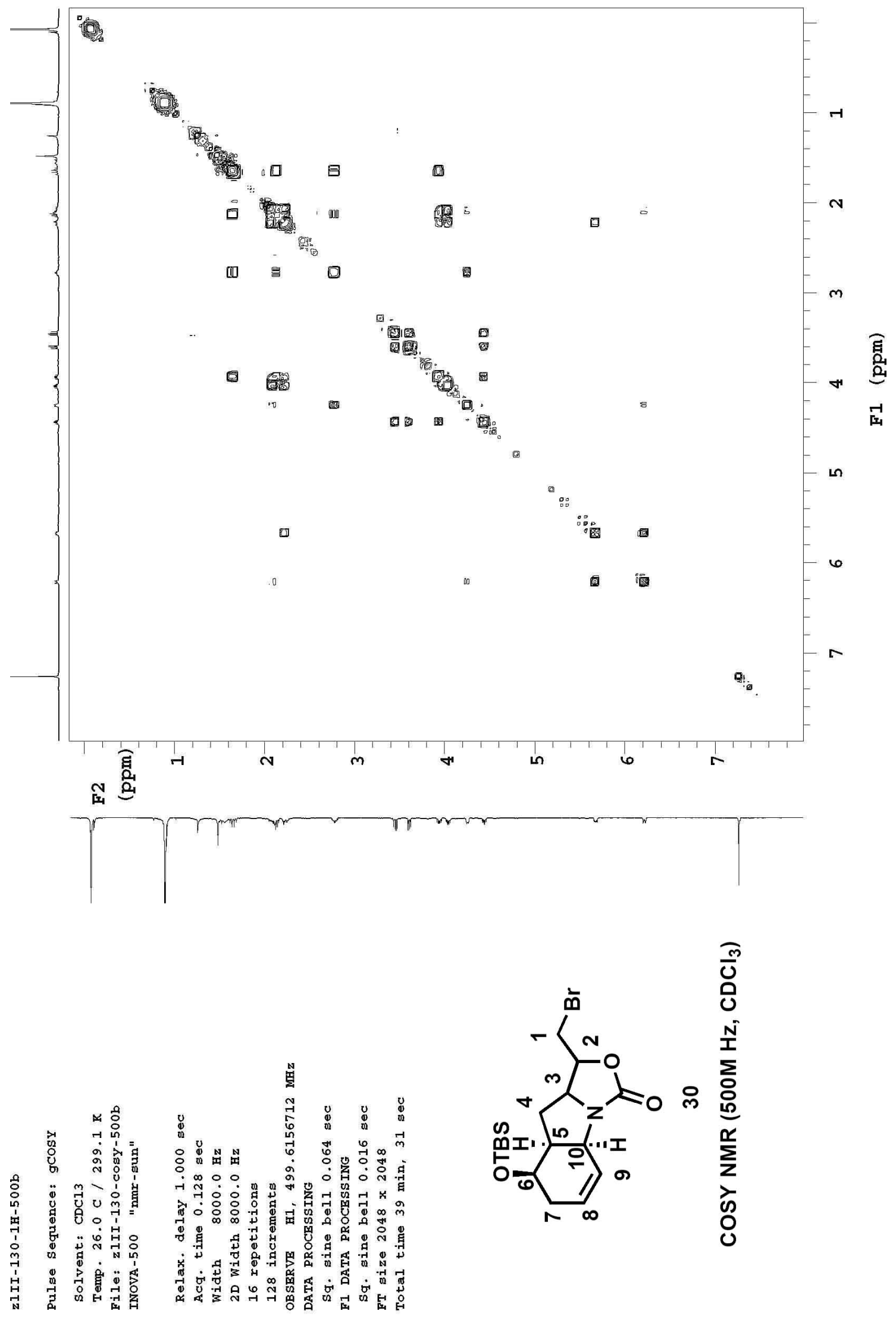


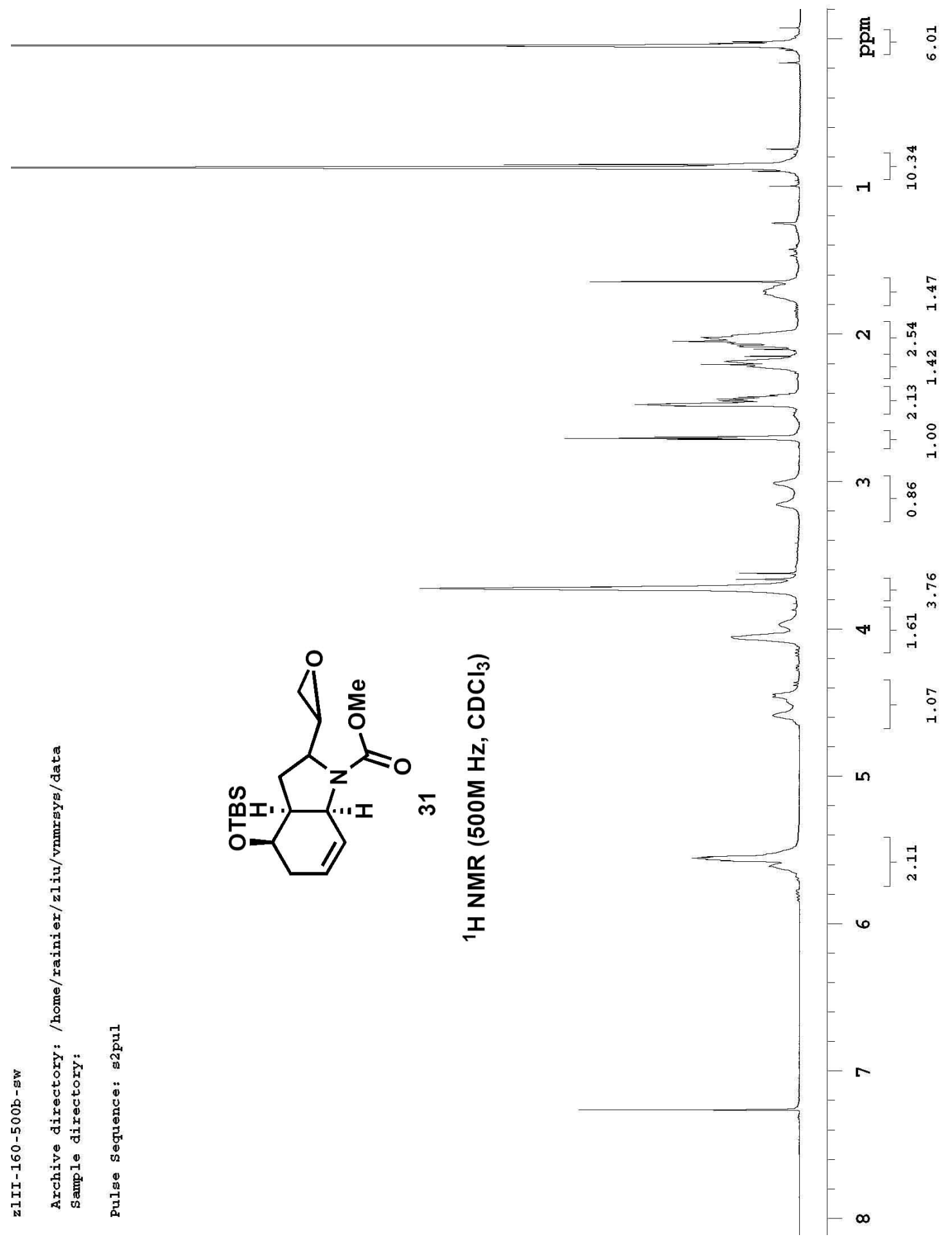




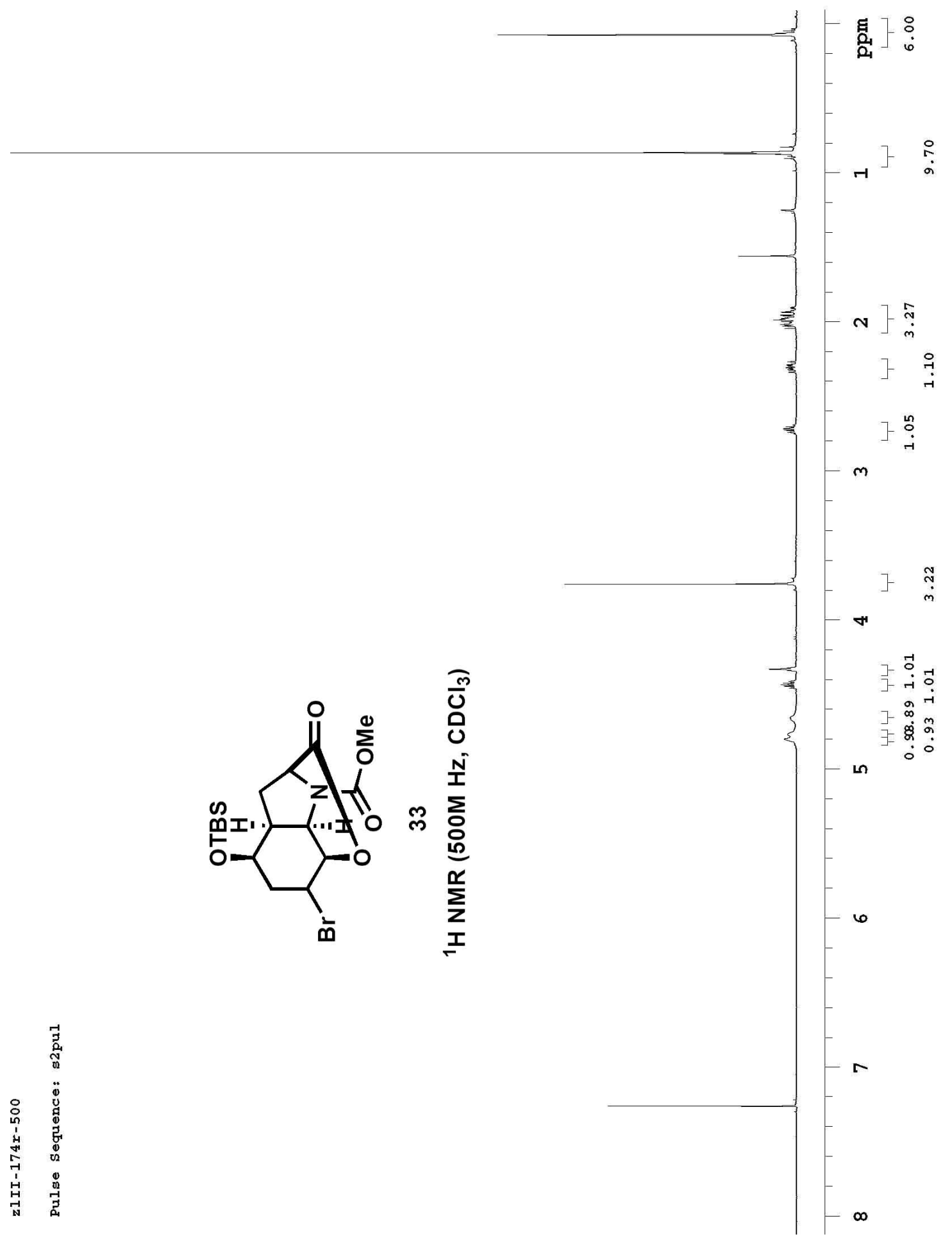




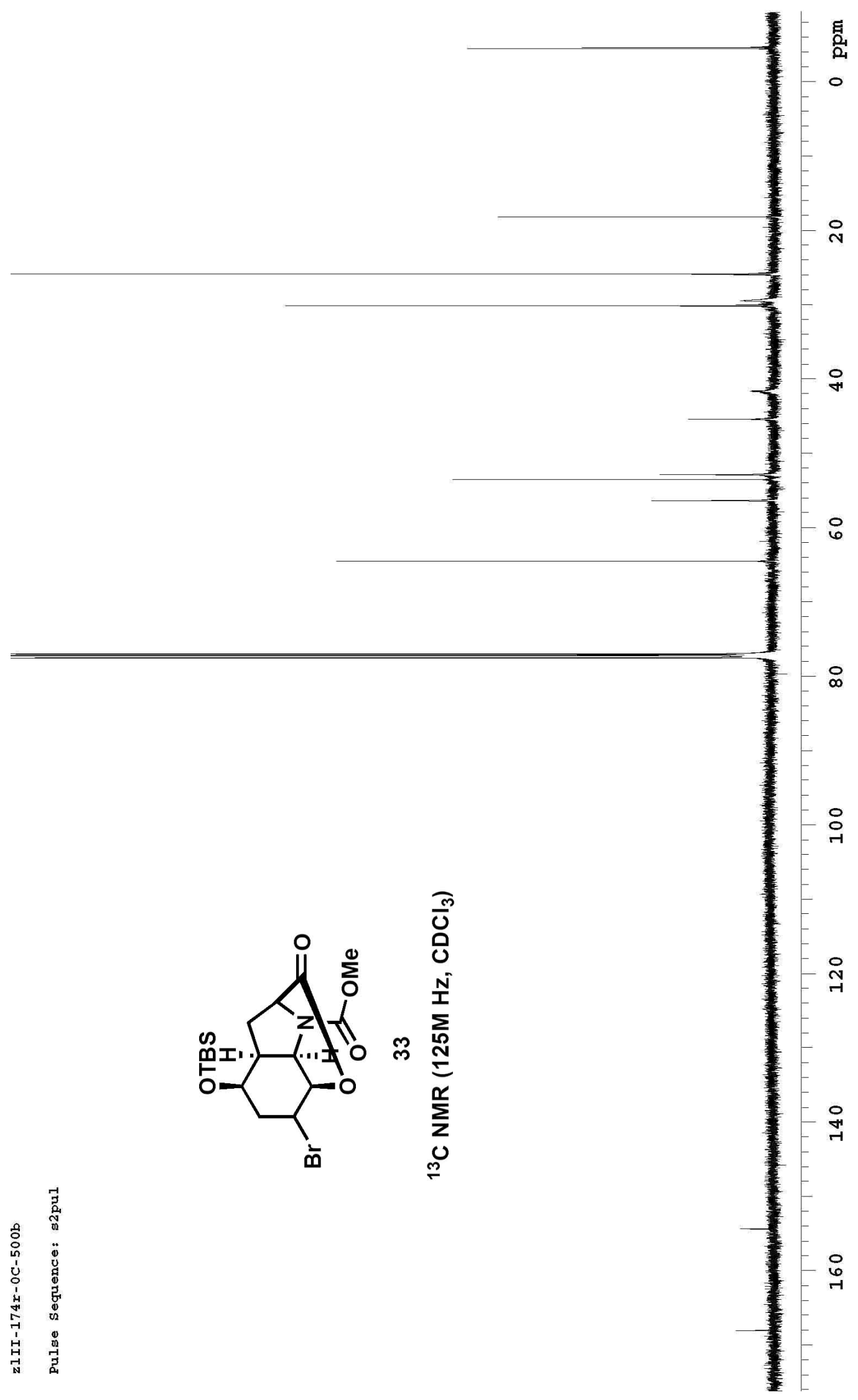




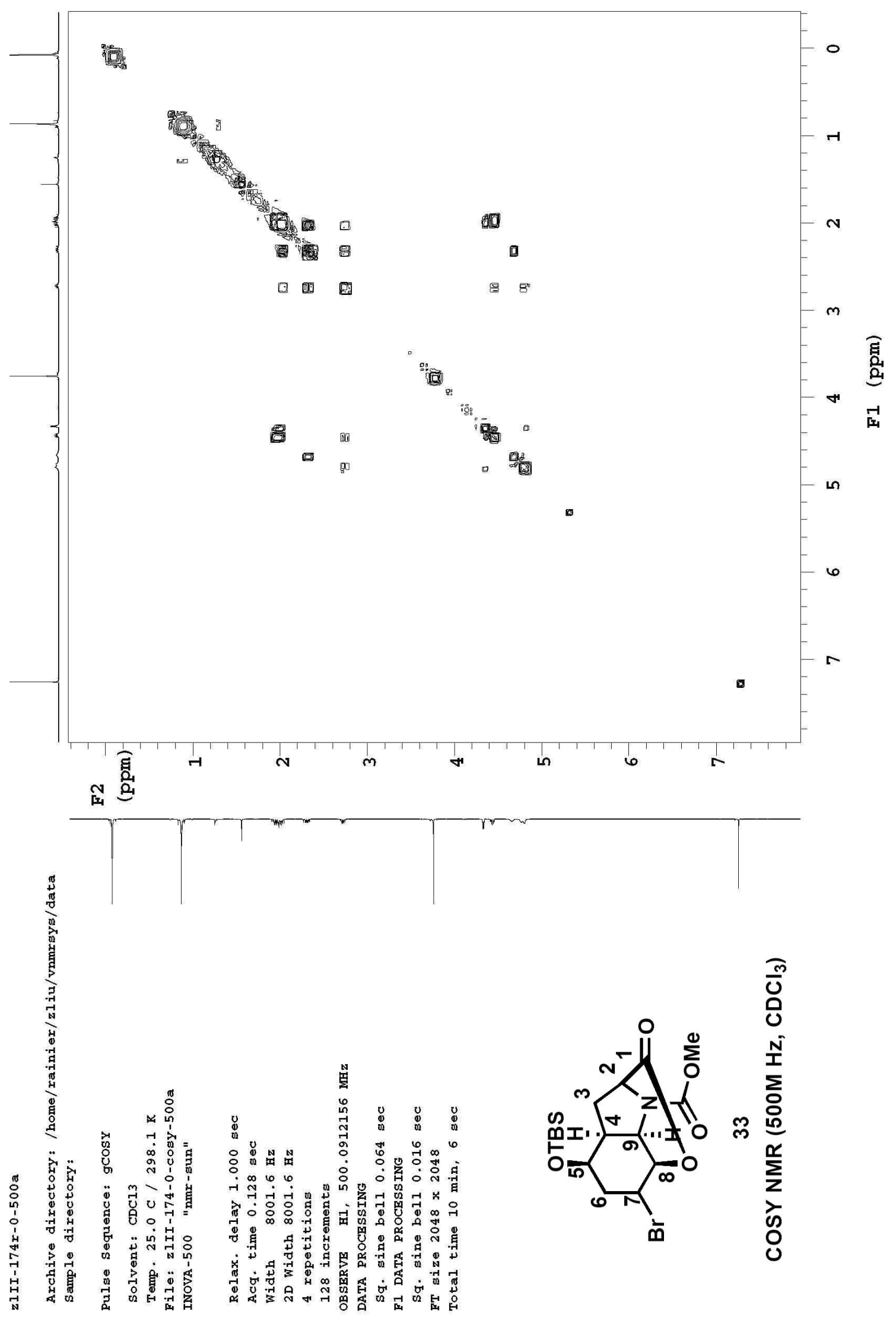

